\title{
Long-Term Stewardship Baseline Report and Transition Guidance
}

Keith Kristofferson

November 2001

Idaho National Engineering and Environmental Laboratory Bechtel BWXT Idaho, LLC 


\title{
Long-Term Stewardship Baseline Report and Transition Guidance
}

\author{
Keith Kristofferson
}

November 2001

Idaho National Engineering and Environmental Laboratory Idaho Falls, Idaho 83415 


\begin{abstract}
Long-term stewardship consists of those actions necessary to maintain and demonstrate continued protection of human health and the environment after facility cleanup is complete. As the Department of Energy's (DOE) lead laboratory for environmental management programs, the Idaho National Engineering and Environmental Laboratory (INEEL) administers DOE's long-term stewardship science and technology efforts. The INEEL provides DOE with technical, and scientific expertise needed to oversee its long-term environmental management obligations complexwide. Long-term stewardship is administered and overseen by the Environmental Management Office of Science and Technology.

The INEEL Long-Term Stewardship Program is currently developing the management structures and plans to complete INEEL-specific, long-term stewardship obligations. This guidance document (1) assists in ensuring that the program leads transition planning for the INEEL with respect to facility and site areas and (2) describes the classes and types of criteria and data required to initiate transition for areas and sites where the facility mission has ended and cleanup is complete. Additionally, this document summarizes current information on INEEL facilities, structures, and release sites likely to enter long-term stewardship at the completion of DOE's cleanup mission. This document is not intended to function as a discrete checklist or local procedure to determine readiness to transition. It is an overarching document meant as guidance in implementing specific transition procedures.
\end{abstract}

Several documents formed the foundation upon which this guidance was developed. Principal among these documents was the Long-Term Stewardship Draft Technical Baseline; A Report to Congress on Long-Term Stewardship, Volumes I and II; Infrastructure Long-Range Plan; Comprehensive Facility Land Use Plan; INEEL End-State Plan; and INEEL Institutional Plan. 


\section{CONTENTS}

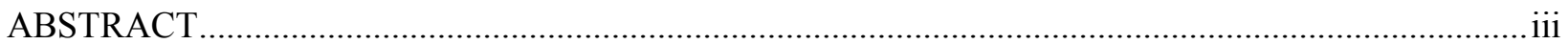

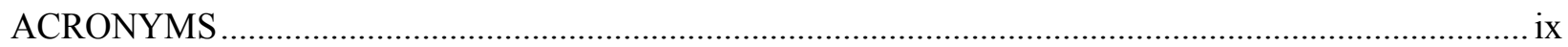

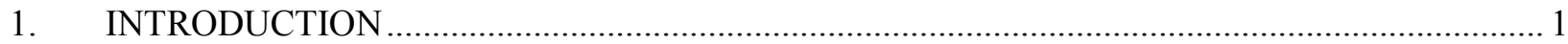

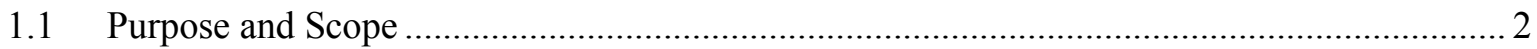

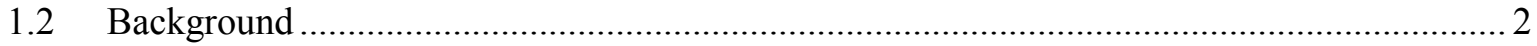

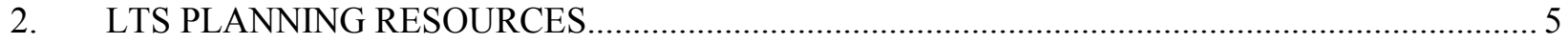

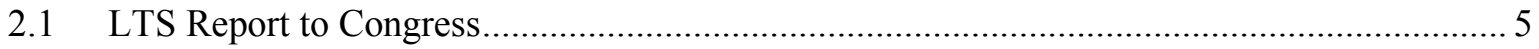

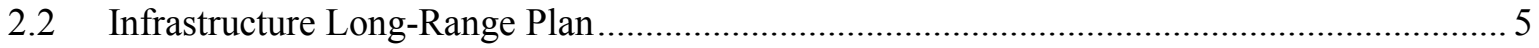

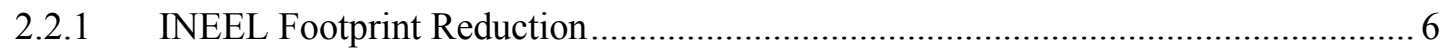

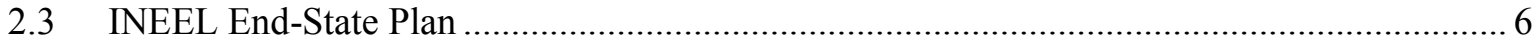

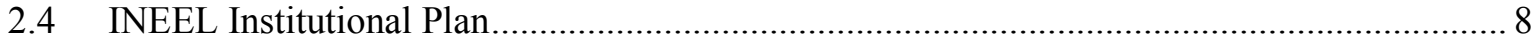

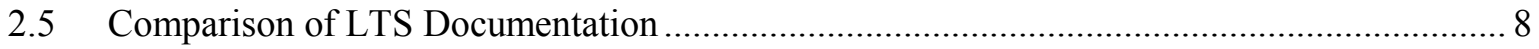

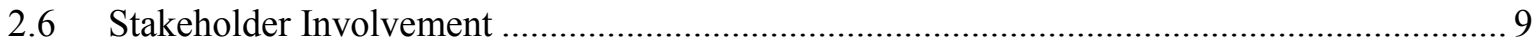

2.6.1 Coordination with Government Agencies..................................................... 10

3. BASELINE PROGRAM AREAS AND INTEGRATION ….................................................. 13

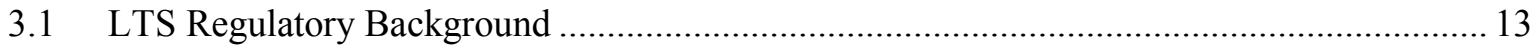

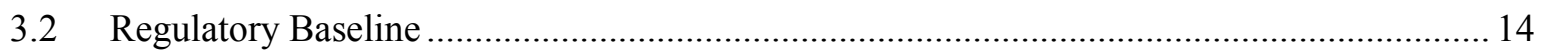

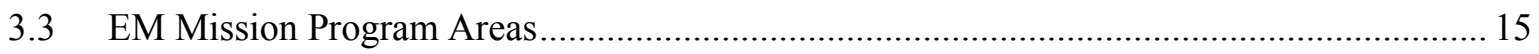

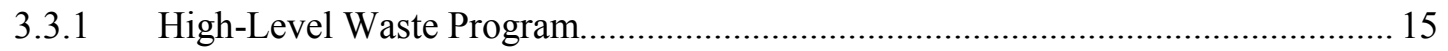

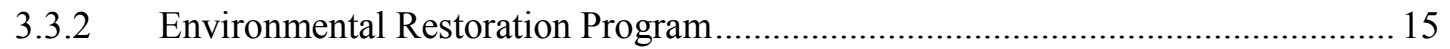

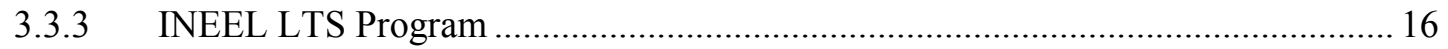

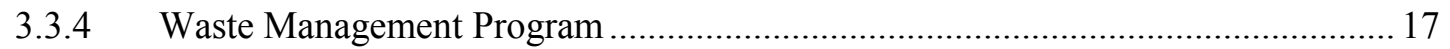

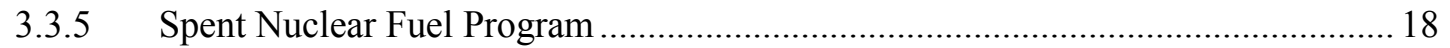

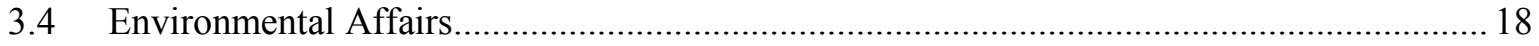

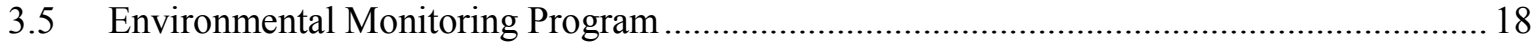




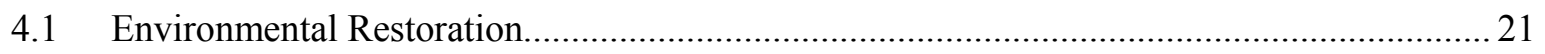

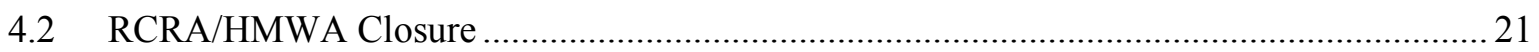

4.3 Voluntary Consent Order ..................................................................................... 22

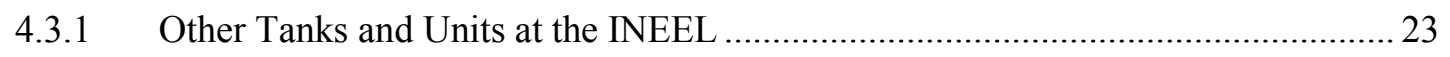

4.4 Deactivation, Decontamination, and Decommissioning .............................................. 23

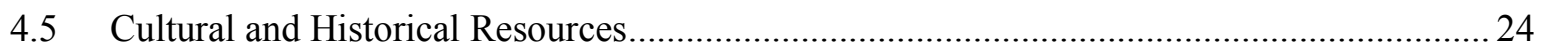

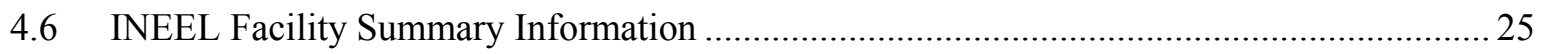

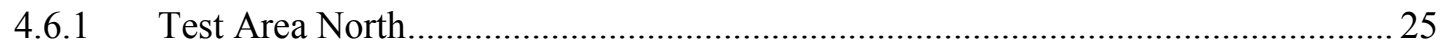

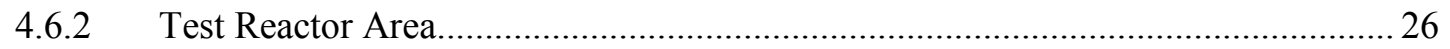

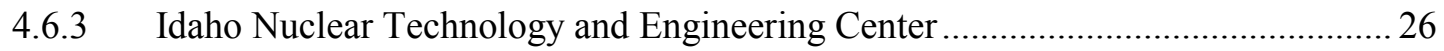

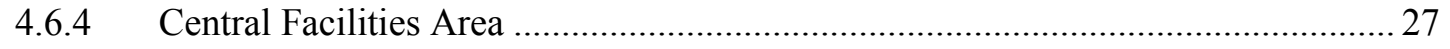

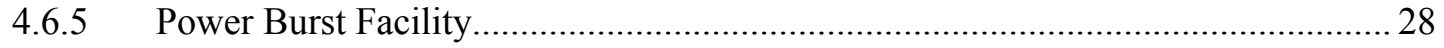

4.6.6 Radioactive Waste Management Complex .................................................... 28

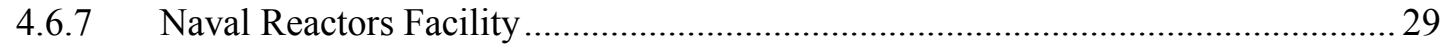

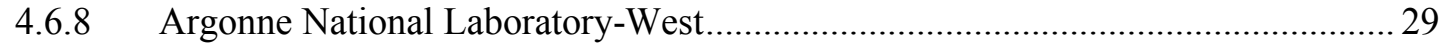

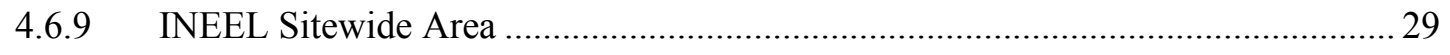

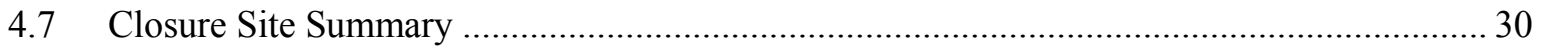

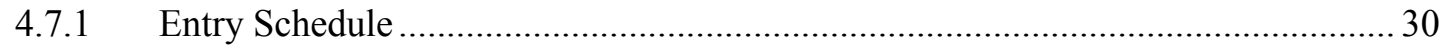

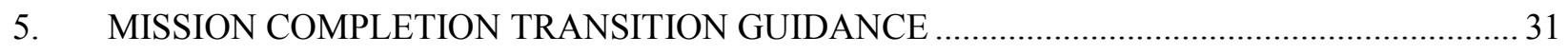

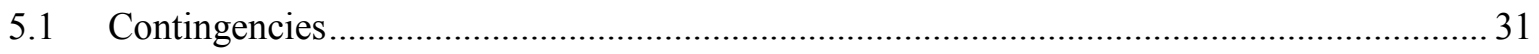

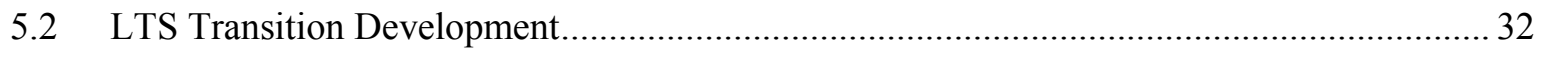

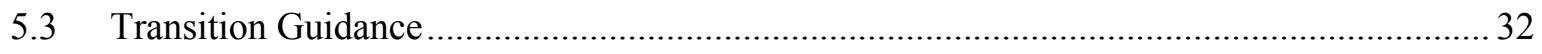

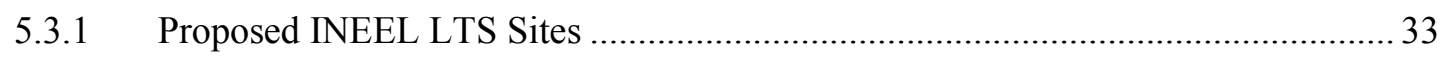

5.3.2 Regulatory-Based Transition Guidance ............................................................ 33

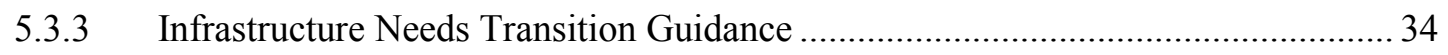




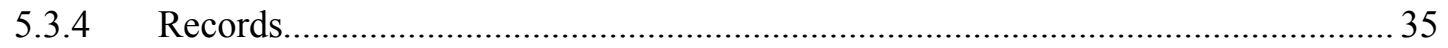

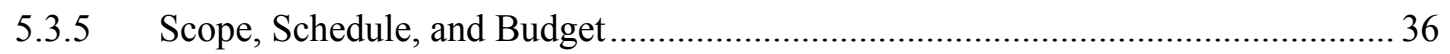

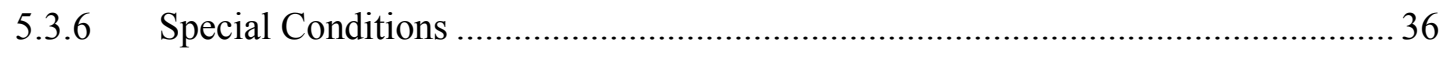

5.3.7 Identification of Long-Term Stewardship National Program

Transition Guidance....................................................................................... 37

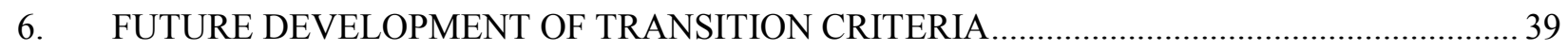

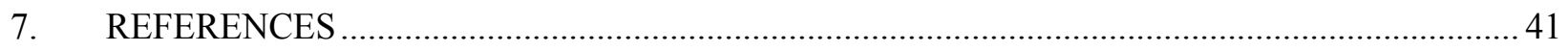

Appendix A-LTS Bibliography

Appendix B - Idaho National Engineering and Environmental Laboratory Facilities End-State Maps

Appendix C - Schedule for INEEL LTS Program entry.

Appendix D-Historic INEEL Architectural Properties List, Assessment of Eligibility, and Mitigation

Appendix E-End-State Plan Critical Path Events, Assumptions, and Issues

Appendix F-Example Documentation to Identify LTS Transition Guidance

\section{TABLES}

1. INEEL facility footprint reduction forecast. 


\section{ACRONYMS}

ACHP Advisory Council on Historic Preservation

AMWTF Advanced Mixed Waste Treatment Facility

ANL-W Argonne National Laboratory-West

AR

Administrative Record

ARA

Auxiliary Reactor Area

BLM Bureau of Land Management

BORAX Boiling Water Reactor Experiment

BRAC Base Realignment and Closure

CERCLA Comprehensive Environmental Response, Compensation, and Liability Act

CFA Central Facilities Area

COC contaminant of concern

CFLUP Comprehensive Facility Land Use Plan

D\&D\&D deactivation, decontamination, and dismantlement

DOE Department of Energy

DOE-ID Department of Energy Idaho Operations Office

EBR I \& II Experimental Breeder Reactor I and II

EIS Environmental Impact Statement

EM Environmental Management

EMS Environmental Management System

EPA Environmental Protection Agency

ER environmental restoration

ERA ecological risk assessment

ERLTS Environmental Restoration Long-Term Stewardship

ESP End-State Plan

FFA/CO Federal Facility Agreement and Consent Order

FS feasibility study

FUSRAP Formerly Utilized Sites Remedial Action Program

HLLW high-level liquid waste

HLW high-level waste

HWMA Hazardous Waste Management Act

ICDF Idaho CERCLA Disposal Facility

ICP Institutional Control Plan

IDEQ Idaho Department of Environmental Quality 


\begin{tabular}{|c|c|}
\hline ILRP & Infrastructure Long-Range Plan \\
\hline INEEL & Idaho National Engineering and Environmental Laboratory \\
\hline INTEC & Idaho Nuclear Technology and Engineering Center \\
\hline IR & information repository \\
\hline LLW & low-level waste \\
\hline LOFT & Loss-of-Fluid Test \\
\hline LTS & long-term stewardship \\
\hline MCP & management control procedure \\
\hline NDAA & National Defense Authorization Act \\
\hline NEPA & National Environmental Policy Act \\
\hline NHPA & National Historic Preservation Act \\
\hline NON & Notice of Noncompliance \\
\hline $\mathrm{NON} / \mathrm{CO}$ & Notice of Noncompliance and Consent Order \\
\hline NRC & National Research Council \\
\hline NRF & Naval Reactors Facility \\
\hline NWCF & New Waste Calcining Facility \\
\hline O\&M & operation and maintenance \\
\hline $\mathrm{OU}$ & operable unit \\
\hline PBF & Power Burst Facility \\
\hline PSO & Program Secretarial Office \\
\hline RCRA & Resource Conservation and Recovery Act \\
\hline RI & remedial investigation \\
\hline ROD & Record of Decision \\
\hline RWMC & Radioactive Waste Management Complex \\
\hline SHPO & State Historic Preservation Office \\
\hline SLP & sewage leach pond \\
\hline $\mathrm{SMC}$ & Specific Manufacturing Capability \\
\hline SNF & spent nuclear fuel \\
\hline SPERT & Special Power Excursion Test \\
\hline SRPA & Snake River Plain Aquifer \\
\hline TAN & Test Area North \\
\hline TID & Tank Inventory Database \\
\hline TFF & Tank Farm Facility \\
\hline TRA & Test Reactor Area \\
\hline TRU & transuranic \\
\hline
\end{tabular}


TSF Technical Support Facility

UST Underground Storage Tank

VCO Voluntary Consent Order

VOC Volatile Organic Compound

WAG Waste Area Group

WCF Waste Calcining Facility

WEDF Waste Engineering Development Facility

WROC Waste Reduction Operations Center

WRRTF Water Reactor Research Test Facility

WM waste management 


\section{Long-Term Stewardship Baseline Report and Transition Guidance}

\section{INTRODUCTION}

As the Department of Energy's (DOE) lead laboratory for Environmental Management (EM) programs, the Idaho National Engineering and Environmental Laboratory (INEEL) administers the long-term stewardship (LTS) science and technology efforts and provides DOE with the managerial, technical, and scientific expertise needed to oversee its long-term EM obligations complexwide. The INEEL LTS Program is currently developing the management structures and plans to complete INEEL-specific LTS obligations. Efforts are under way to develop policies and systems by which to operate the INEEL LTS Program including, for example, how to determine if a given site is functionally and administratively ready to move from a cleanup mission to stewardship activities.

LTS is defined as:

"...all activities necessary to ensure protection of human health and the environment following completion of cleanup...includes all engineered and institutional controls designed to contain or to prevent exposure to residual contamination and waste...." (DOE 2001a)

DOE considers LTS to be an integral part of decision-making during and after the remediation process. Thus, DOE now requires the preparation of an LTS plan early in the cleanup process so that LTS requirements and costs can be considered during cleanup (DOE 2001a).

LTS consists of those actions necessary to maintain and demonstrate continued protection of human health and the environment after DOE has completed facility cleanup, which is defined as completion of Comprehensive Environmental Response, Compensation, and Liability Act (CERCLA) remediation and/or Resource Conservation and Recovery Act (RCRA) closure and deactivation, decontamination, and dismantlement (D\&D\&D) actions. These LTS actions primarily include groundwater and environmental media surveillance and monitoring for contaminant release and movement, maintenance of remediation structures (caps, etc.), maintenance of flood control diversion structures, and records management.

In accordance with CERCLA, contained and capped areas will require regular inspections (as required by the specific Records of Decision [ROD] for each area), monitoring, and maintenance. LTS activities for facilities that have transitioned to the INEEL LTS Program will include maintaining facility-filtered off-gas systems, preventing and cleaning up contaminant releases, and maintaining surveillance and monitoring. These LTS actions will occur for an undetermined period of time.

For the purposes of this document, the INEEL EM cleanup mission is considered complete when the following five criteria are met (DOE-EM 2000):

- Deactivation or decommissioning of all facilities currently in the INEEL EM Program has been completed, excluding any long-term surveillance and monitoring

- All releases to the environment have been cleaned up in accordance with agreed-upon cleanup standards

- Groundwater contamination has been contained or long-term treatment or monitoring is in place 
- Nuclear material and spent fuel have been stabilized and/or placed into safe, long-term storage

- $\quad$ Legacy waste (i.e., waste produced by past nuclear weapons production activities, with the exception of high-level waste [HLW]) has been treated and disposed of in an approved manner.

\subsection{Purpose and Scope}

This document serves to assist in ensuring that the INEEL LTS Program guides INEEL planning with respect to performing stewardship activities at facility areas and cleanup sites. This guidance is to be used in conjunction with programmatic and regulatory commitments that serve as drivers for LTS decisions. These decisions include determining specifically when a given facility or site has met the criteria for entering the INEEL LTS Program. This guidance document describes the classes and types of criteria and data required to initiate transfer of areas and sites where the facility mission has ended and cleanup is complete. Additionally, this document summarizes current information on INEEL facilities, structures, and release sites that are likely to enter the INEEL LTS Program at the completion of DOE's cleanup mission. The LTS transition guidance presented in this document is intended to be general in nature and should be used in conjunction with programmatic and regulatory requirements, which are generally implemented at each site and laboratory in the DOE complex.

Information presented herein was provided primarily by the INEEL EM Programs of Environmental Restoration (ER), D\&D\&D, Spent Nuclear Fuel (SNF), HLW, and Waste Management (WM). These programs are focused on EM's cleanup mission and on compliance with CERCLA, Hazardous Waste Management Act (HWMA) (Subtitle C)/RCRA regulations, consent orders and agreements, and DOE orders. Substantial additional detailed information available in other areas that may impact stewardship in other INEEL programs (e.g., non-RCRA, Subtitle C tanks) was not included in this analysis.

\subsection{Background}

The INEEL consists of nine facility areas. Eight major facility areas are scattered across a $2,276-\mathrm{km}^{2}\left(890-\mathrm{mi}^{2}\right)$ section of desert in southeastern Idaho. These facilities are collectively referred to as the "Site."

The eight Site facilities include:

- $\quad$ Test Area North (TAN) - TAN consists of facilities for handling, storage, examination, and research of spent nuclear fuel. TAN also houses the Specific Manufacturing Capability Project, which makes armor packages for Army tanks.

- Test Reactor Area (TRA) - TRA is the world's most sophisticated materials testing complex, with extensive facilities for studying the effects of radiation on materials, fuels, and equipment.

- $\quad$ Idaho Nuclear Technology and Engineering Center (INTEC) - INTEC provides safe interim storage for government-owned SNF. INTEC currently develops new approaches and technologies to prepare spent fuel and other nuclear materials for eventual disposal in a national repository. It also is the center for the INEEL's HLW treatment program.

- $\quad$ Central Facilities Area (CFA) - CFA houses many technical and support services including monitoring and calibration laboratories, fire protection, medical services, warehouses, vehicle and equipment pools, and bus operations. 
- Waste Reduction Operations Complex and Power Burst Facility (WROC/PBF) - WROC/PBF is housed in an area formerly used for reactor operations. WROC/PBF provides safe treatment, storage, and recycling of the INEEL's radioactive, mixed, and industrial/commercial wastes.

- $\quad$ Radioactive Waste Management Complex (RWMC)-RWMC studies the strategies for waste storage, processing, and disposal. Approximately 32,000 drums containing waste are safely stored at this facility.

- $\quad$ Naval Reactors Facility (NRF) - NRF is the birthplace of the U.S. Nuclear Navy. NRF receives and examines Naval SNF, and works together with other INEEL facilities to continually improve nuclear propulsion systems.

- $\quad$ Argonne National Laboratory-West (ANL-W) - ANL-W is part of Argonne National Laboratory operated by the University of Chicago. ANL-W conducts research and development and operates facilities for DOE in areas of national concern including energy, nuclear safety, SNF treatment, nonproliferation, decommissioning and decontamination technologies, and nuclear material disposal.

Buildings and structures at the Site are clustered within these facilities, which are typically less than a few square miles in size and separated from each other by miles of undeveloped land. The INEEL land outside the boundaries of these primary facilities and inside the INEEL perimeter boundary is referred to as the Sitewide Area.

The entire INEEL supports DOE's missions of energy resources, science, national security, and environmental quality, which include conducting and completing environmental cleanup of the Site responsibly. LTS follows the process of environmental cleanup and provides for long-term protection of human health, safety, and the environment. 


\section{LTS PLANNING RESOURCES}

Key documents used in the development of this guidance included the Long-Term Stewardship Draft Technical Baseline (INEEL 2001a); A Report to Congress on Long-Term Stewardship, Volumes I and II (DOE 2001a); Infrastructure Long-Range Plan (ILRP) (INEEL 2001b); Environmental Management End-State Planning Document (DOE 1998a); and INEEL Institutional Plan (INEEL 2000a). LTS planning information was also obtained from the Integrated Planning and Accountability Budget System. Many other references were consulted but not cited. These references are provided in a bibliography in Appendix A.

\subsection{LTS Report to Congress}

The FY 2000 National Defense Authorization Act (NDAA) Conference Report (House of Representatives 1999) requested that DOE submit to Congress a report on DOE's existing and anticipated LTS obligations at sites where ER activities are complete or will be complete by 2006. The resulting document, A Report to Congress on Long-Term Stewardship (known henceforth as the LTS Report to Congress), Volumes I \& II (DOE 2001a), includes a section specific to the INEEL that details INEEL LTS activities.

In general, LTS activities include groundwater monitoring, remediation structure maintenance (caps, etc.), flood control diversion structure maintenance, and records management. In accordance with CERCLA, contained and capped areas will require regular inspections (as required by the specific Records of Decision [ROD] for each area), monitoring, maintenance, and institutional controls. LTS activities for deactivated facilities pending final D\&D\&D will include maintaining facility-filtered off-gas systems, and continuing surveillance and monitoring.

Several sources of information were used in the preparation of the INEEL section in the LTS Report to Congress (DOE 2001a) in addition to the documents previously mentioned. The INEEL Comprehensive Facility and Land-Use Plan (DOE Idaho Operations Office [DOE-ID] 1997a) includes a discussion of current land use and projections of future land use. Future projections of the likely INEEL configuration in $25,50,75$, and 100 years are based on assumptions and constraints presented in the plan.

\subsection{Infrastructure Long-Range Plan}

The ILRP (INEEL 2001b) incorporates previous planning efforts focused on identifying the end-state of each INEEL facility. The ILRP provides a forecast of the infrastructure, which includes the land, facilities, and capital equipment needed for the INEEL to support DOE missions and initiatives (described in the INEEL Institutional Plan, INEEL 2000a). To complete these missions, the INEEL infrastructure must be aligned with the mission initiatives. The ILRP presents pertinent information (i.e., uses, end dates, and costs) on all of the areas and facilities under DOE-ID purview; as such, the plan excludes ANL-W and NRF from discussion. Information on the end date for buildings and structures is especially useful for long-term D\&D\&D planning and scheduling. The ILRP will be updated annually and provide the INEEL LTS Program planning with an important information source to identify and prioritize future facility D\&D\&D projects and other operations mission needs.

The scope of the ILRP includes a description of the current infrastructure and conditions (both Sitewide and by facility, including Idaho Falls facilities), forecasts of future facility populations, forecasts of infrastructure viability versus future needs, and funding requirements to maintain or replace a given facility. The ILRP used the End-State Plan (ESP) for discussions for facility end states, specific facility 
mission overviews, estimates for building and mission end dates, and infrastructure replacement or disposition and cost.

The ILRP succinctly identifies the hierarchy of INEEL planning documentation types (in order of importance):

1. DOE strategic plans

2. DOE mission strategic plans

3. DOE mission research and development portfolios and program roadmaps

4. Laboratory institutional plans

5. ILRPs

6. Tactical plans

7. Budget plans

8. Program execution plans

9. Annual performance plans.

\subsubsection{INEEL Footprint Reduction}

INEEL infrastructure plans and data were also reviewed for applicability to transition to LTS. The INEEL facility footprint reduction initiatives currently under way were also included in the analysis. The facilities and buildings at the INEEL are being evaluated to determine cost savings associated with reduction of facility space. The opportunity to reduce space for each site area (i.e., CFA and INTEC) is being assessed. Table 1 lists the facilities and the reduction opportunity in the form of reduced buildings, facility area, and population.

The INEEL LTS Program will interface electronically with the Footprint Reduction Initiative and Facility Planning through use of the Comprehensive Facility and Land-Use Plan Web site. The INEEL LTS Program will use data from this site and work with the Infrastructure Area Planner to assess facilities, sites, areas, abilities, and timeframes for LTS transition.

\subsection{INEEL End-State Plan}

The INEEL ESP (DOE 1998a) represents the philosophy and projections in 1998 about the final disposition of the INEEL and its facilities. The purpose of the ESP was to present a depiction of each facility at the completion of its mission and cleanup (thus, its "end state"). Although the ESP did not contain sufficient scope, schedule, or cost estimates to attain a comprehensive depiction of the facilities, the ESP did identify four levels of planning used in the conceptualization of the end states. The levels are defined as:

- $\quad$ Level 1 -overall INEEL

- $\quad$ Level 2 - each facility area (e.g., CFA and TRA) 


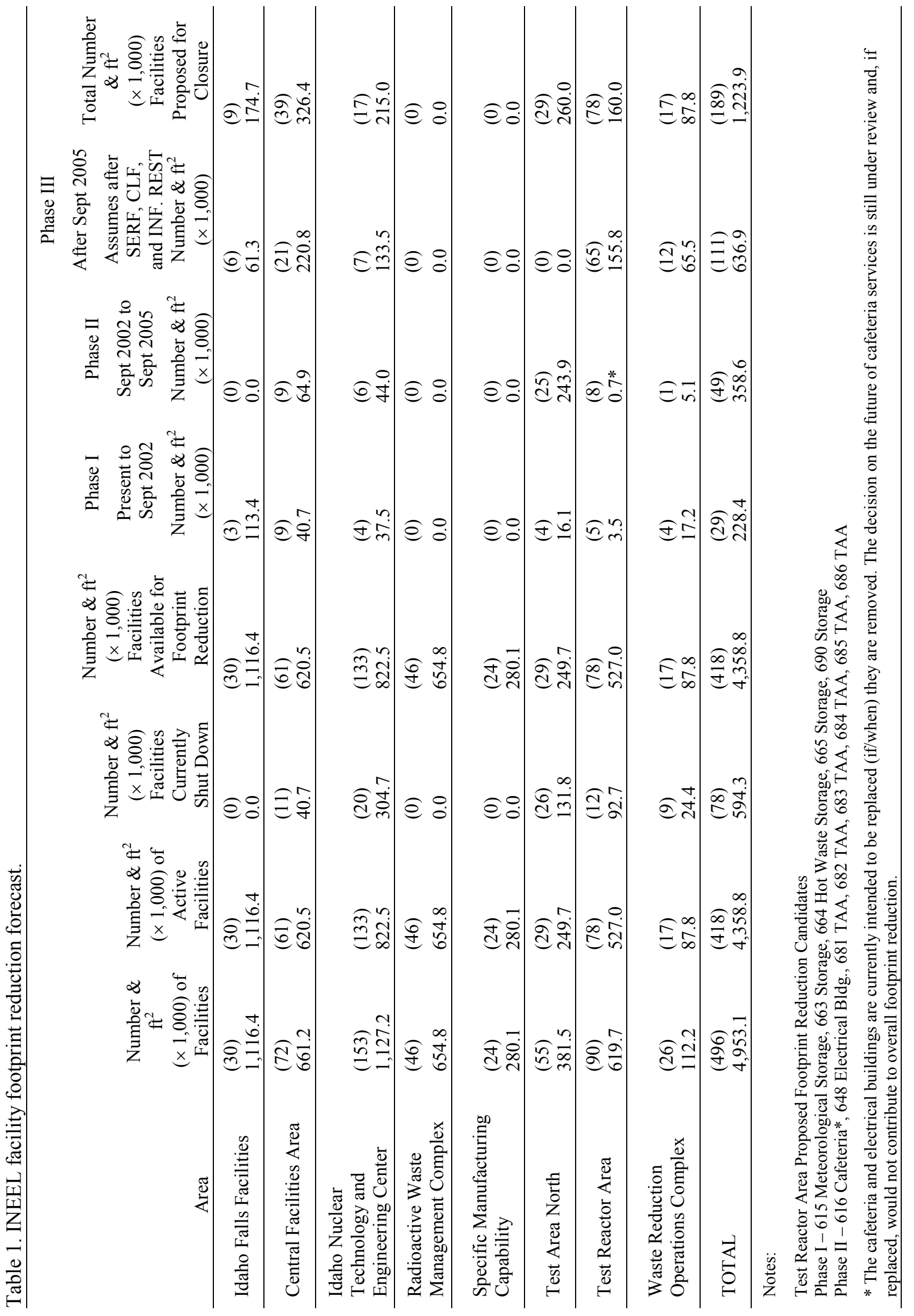


- $\quad$ Level 3-individual buildings, sites, or sections of sites

- $\quad$ Level 4 - individual items or pieces of equipment.

Both Levels 3 and 4 were to be identified and maintained by facility-specific owners and, as such, were not detailed in the ESP.

A facility will be transferred to the INEEL LTS Program when it completes the required cleanup and reaches its end state (although some closure activities may take place years in advance of that transfer). While the potential for future site missions are recognized in the ESP, the primary activities and programs discussed included CERCLA, operations, and Settlement Agreement (DOE et al. 1995) actions. The ESP identifies key stakeholders but, as with the ILRP, excludes those portions of the INEEL not managed by DOE-ID (NRF and ANL-W).

End-state planning predicts, with the best available data, the final condition of a given facility at the end of the DOE institutional control period (assumed to be 100 years). Emphasis was given to ER sites where residual wastes will be left in place, such as landfills, etc. A conceptual end-state map was prepared for each INEEL facility (see Appendix B) that shows the potential locations of buried wastes, landfills, tanks, and other sites that must be monitored, maintained, or controlled.

\subsection{INEEL Institutional Plan}

The INEEL Institutional Plan (INEEL 2000a) presents summaries of laboratory objectives, strategies, and proposed initiatives for the 5-year period from 2001 to 2005 . Seven initiatives that support DOE missions and objectives are identified in the plan. Of the seven, three initiatives directly or indirectly support LTS and include:

- $\quad$ Long-Term Environmental Stewardship-This initiative focuses on coordinating investments in science and technology that result in significant risk and cost reductions, while protecting human health and the environment.

- $\quad$ Subsurface Science-This research program initiative investigates the processes occurring beneath the earth's surface. Improved understanding of the subsurface will be used to more accurately predict the transport, transformation, and monitoring needs of contaminants and provide for better science-based decision-making.

- Waste Treatment and Disposition-This initiative uses program integration and research and development expertise to complete the treatment and disposition of legacy waste inventories such as spent nuclear fuel, HLW, and transuranic (TRU) waste. Collaborating with other national laboratories and DOE, the INEEL applies its skills in waste characterization, treatment, packaging, and transportation across the DOE complex.

\subsection{Comparison of LTS Documentation}

In terms of end states, each of the reports grouped INEEL facilities and waste sites differently. For example, while the ESP presents end states in a geographic manner (TRA, INTEC, TAN, etc.), the LTS Report to Congress used both geographic proximity and similarity of contaminants or cleanup actions to develop its INEEL groups. 
Each LTS document shared similar assumptions for end-state prediction (e.g., no further action on a release site means no further action and a geologic repository will be opened off-Site for disposal of HLW). Outside of these basic assumptions, there is very little overlap in discussion, as the reports had different focuses, levels of detail, and facility groupings. Both the ESP and LTS Report to Congress report focused on CERCLA remedial actions, having little discussion about the ultimate disposition of buildings and equipment (which has potential to impact the facility end state). Meanwhile, consistent with its stated purpose, the ILRP focused on building and equipment (infrastructure) condition and replacement, not on LTS.

Each of the four LTS documents contains assumptions that are no longer current; some may affect LTS planning (e.g., ESP assumes V-tank vitrification, variable end dates for Specific Manufacturing Capability [SMC] mission, and TAN disposition; assumption of INTEC cleanup complete in 2008; and LTS activities ending in 2095, while the Boiling Water Reactor Experiment (BORAX) LTS continues until 2316). However, despite these differences, the reports are generally consistent with each other.

\subsection{Stakeholder Involvement}

A commitment to stakeholder involvement has been central to all efforts within the INEEL's EM planning process. This also will be the case in the development of the INEEL's strategic LTS plan. The INEEL has four goals for involving stakeholders:

1. Inform stakeholders about environmental management projects at the INEEL

2. Assist stakeholders in understanding changes in the INEEL's EM work and budget allocations

3. Invite stakeholder participation and provide feedback concerning stakeholder interests

4. Involve stakeholders in the development of the INEEL LTS strategic and implementation plans.

For INEEL programs, such as LTS, stakeholder involvement typically is implemented by the individual program, with coordination through the DOE-ID Office of Communications' public involvement coordinator and the INEEL Communications Department. The INEEL Citizens Advisory Board and other stakeholder groups have been, and will continue to be, briefed and provided specific recommendations throughout the LTS planning process. A comprehensive EM listing of stakeholders is available through the DOE-ID Office of Communications for use in this process.

The principal stakeholder database consists of nearly 7,000 names and includes local, state, and federal officials; tribal council members; special interest groups; business interests; INEEL employees; and individual citizen and noncitizen stakeholders. Following is a summary listing, which is not intended to be comprehensive or exclusive, of identified stakeholders that receive communication via personal contact or written information.

\section{Units of Government}

- $\quad$ State INEEL Oversight Program

- $\quad$ Shoshone-Bannock Tribes, Tribal Council, and Tribal members

- $\quad$ Local, state, and federal government elected officials

- $\quad$ Local, state, and federal government agencies 


\section{Media}

- $\quad$ Local and national electronic and print media

Advisory Board

- $\quad$ INEEL Citizens Advisory Board

General Public and Special Interest Groups

- $\quad$ General Public

- $\quad$ Civic organizations

- $\quad$ Coalition 21

- Environmental Defense Institute

- $\quad$ Environmental interest groups (Snake River Alliance)
- $\quad$ INEEL employee associations

- $\quad$ Keep Yellowstone Nuclear Free

- $\quad$ Labor and Trade Unions

- $\quad$ League of Women Voters

- $\quad$ The Nature Conservancy.

\subsubsection{Coordination with Government Agencies}

A commitment to coordination with all involved agencies and governmental entities has been central to all efforts within the INEEL's EM planning process. To maintain regulatory compliance and to ensure broad stakeholder involvement, this also will be the case in the development of the INEEL's LTS plans. The specific process and procedures to be followed to ensure broad-based agency coordination are currently conducted within the context of the various EM program offices described in Section 4.

DOE-ID will be responsible for coordinating stakeholder involvement and for providing draft copies of any discussion prepared in the development of the INEEL's LTS plans to stakeholders such as the agencies and entities listed below. Copies may be available to other interested government agencies upon request. The following list gives examples of primary agency stakeholders; however, the stakeholder database available through the DOE-ID Office of Communications should be consulted to ensure that the most current stakeholder listing is used.

\section{Federal Agencies}

- $\quad$ Argonne National Laboratory

- $\quad$ Defense Nuclear Facilities Safety Board

- U.S. Department of Agriculture

- $\quad$ Natural Resources Conservation Service

- U.S. Department of Commerce

- National Oceanic \& Atmospheric Administration
- Nuclear Regulatory Commission

- U.S. Department of Interior

- Bureau of Land Management National Park Service

- Fish and Wildlife Service

- U.S. Geological Survey

- U.S. Department of Navy 
- Naval Reactors Idaho Branch Office

- Naval Sea Systems Command

- U.S. Department of Transportation

- U.S. Environmental Protection Agency, Region 10

- U.S. Department of the Army

\section{Idaho State Agencies}

- $\quad$ State of Idaho INEEL Oversight Program

- State of Idaho Department of Environmental Quality

- $\quad$ State of Idaho Department of Fish and Game

- State of Idaho Department of Labor
- State of Idaho Department of Lands

- $\quad$ State of Idaho Department of Parks and Recreation

- $\quad$ State of Idaho Department of Transportation

- $\quad$ State of Idaho Department of Water Resources

\section{Local Cities}

- Idaho Falls, Pocatello, Blackfoot, Twin Falls, Jackson, Wyoming, etc.

\section{Native American Tribes}

- The Shoshone-Bannock Tribes, Idaho

\section{State of Wyoming}

- $\quad$ Specific agencies currently under consideration. 


\section{BASELINE PROGRAM AREAS AND INTEGRATION}

\subsection{LTS Regulatory Background}

Statutes, regulations, compliance agreements, DOE orders and directives, and site-specific documents and policies mandate aspects of LTS. However, many INEEL LTS actions have yet to be defined in the interaction to occur between DOE, stakeholders, and the various regulatory authorities with roles in the stewardship of the public domain. DOE's involvement in LTS emerged from the agency's focus on improving the management of accelerated site cleanup programs. Specifically, in October 1999, DOE published From Cleanup to Stewardship, A Companion Report to Accelerating Cleanup: Paths to Closure and Background Information to Support the Scoping Process Required for the 1998 PEIS Settlement Study (DOE 1999a). This effort provides the INEEL LTS Baseline for the anticipated LTS planning activities that will occur across the DOE complex. Further background on LTS and DOE's efforts to address the terms of a December 1998 lawsuit settlement agreement ${ }^{\text {a }}$ is available in DOE's LTS Report to Congress (DOE 2001a).

Although statutory and regulatory requirements provide important guidance in the formulation of LTS transition criteria, existing mandates designed to control pollution or protect resources do not clearly delineate the full scope of future activities tied to LTS. Even so, additional research, analysis, and coordination of this facet of transition criteria will be necessary to ensure the development of effective LTS implementation strategies.

One useful reference tool available for an assessment of regulatory criteria related to LTS is maintained on the DOE/EM Web site (http://lts.apps.em.doe.gov/center/stewlink0.asp). This Web site provides links to a 20-page collection of "Major Environmental Statutes, Regulations, and Executive Orders for Long-Term Stewardship at DOE Sites." This resource is regularly updated through coordinated efforts between DOE's EM-51 Office of LTS and Environmental Policy and Guidance (EH-41).

The Web site also contains tables that summarize and link the user to DOE orders, policies, guidance, documents, and official communication relevant to the LTS statutes, regulations, and executive orders, described previously. These hyperlinks aid in the identification of additional applicable regulation promulgated by the U.S. Environmental Protection Agency (EPA) and U.S. Nuclear Regulatory Commission. Similarly, other federal policies and guidance pertinent to implementation of LTS are provided. A hyperlink through the EPA Web site does provide further links to a limited set of State of Idaho statutes and regulations affecting EPA-approved programs for the regulation of air quality, waste management, and water quality by the Idaho Department of Environmental Quality (IDEQ).

The EM LTS Web site also cites two Secretarial Memoranda (Glauthier 2000; Huntoon 2001) that require site-specific LTS plans for each DOE facility. Accordingly, any "LTS Mission Completion Plan" prepared by the INEEL must include a compilation and analysis of all relevant State of Idaho statutes and regulations, pertinent tribal government treaties, and other site-specific authorities. An Idaho and INEELspecific reference tool that follows the lead and format of the Office of EM LTS Web site resource would be useful to LTS planning.

a. Natural Resources Defense Council, et al., v. Richardson, et al., Civ. No. 97-936 (SS) (D.D.C.), December 12, 1998. 


\subsection{Regulatory Baseline}

The site-specific authorities, forming the regulatory baseline, that need to be incorporated into INEEL LTS planning include the following:

- $\quad$ Selected remedies, institutional controls, and operations and maintenance (O\&M) plan measures will be included in post-ROD documents like the O\&M Plan and the Institutional Control plans and may be included in each of the RODs signed for each waste area group (WAG) and the respective operable units (OUs) at the INEEL under the jurisdiction of CERCLA.

- $\quad$ Criteria set forth in the Federal Facility Agreement and Consent Order (FFA/CO), and implemented by DOE, the Idaho Department of Health and Welfare (IDHW) ${ }^{\mathrm{b}}$ and EPA, Region 10 (EPA et al. 1991).

- $\quad$ Stipulations contained in the Notice of Noncompliance and Consent Order (NON/CO) (IDHW 1992) executed between DOE and the State of Idaho that focuses on the disposition of INTEC HLW tanks and calciner permitting.

- Milestones and provisions contained the "Settlement Agreement" executed by the State of Idaho, DOE, and the U.S. Navy (DOE et al. 1995), the INEEL Site Treatment Plan (DOE 1998b) and Consent Order entered into by the State of Idaho and DOE pursuant to the Federal Facility Compliance Act of 1992 (November 1, 1995).

- $\quad$ Stipulations contained in the Voluntary Consent Order (VCO) entered into by DOE and the State of Idaho on June 14, 2000, to establish an action plan with enforceable milestones within which DOE agreed to achieve compliance with the Idaho HWMA program, as approved by EPA, under RCRA.

- Terms and conditions of the site-specific INEEL RCRA permit closure plan prepared to describe removal and decontamination of wastes and waste residues. The associated contingency plan contains provision to minimize hazards to human health and the environment from fires, explosions, or any unplanned sudden or gradual release of hazardous waste or its constituents to any environmental media.

CERCLA is implemented at the INEEL with the FFA/CO (EPA et al. 1991). The FFA/CO designates a remedial project manager in DOE-ID; EPA, Region 10; and the IDHW, who manage investigation and cleanup activities.

The FFA/CO specifies the division of the INEEL into 10 WAGs. Within each WAG, known or suspected areas of contamination are assigned to an OU. This strategy allows the agencies to efficiently focus available cleanup resources on those areas that could potentially pose risk to human health and the environment. A brief summary of WAGs 1 through 10 is presented in Section 5.

b. On July 1, 2000, the Division of Environmental Quality, a division of the IDHW, was elevated to the IDEQ. This department now oversees the implementation of the FFA/CO. 


\subsection{EM Mission Program Areas}

The INEEL EM Program is divided into four program offices to accomplish its broader mission: the HLW Program, ER Program, WM Program, and SNF Program. Each of these program offices has a role in addressing DOE cleanup, waste disposal, and LTS responsibilities.

\subsubsection{High-Level Waste Program}

This program manages HLW at the INTEC. Both the current management plan and the disposition of the INEEL's HLW within an LTS program will be, to an extent, determined by various regulatory criteria. These criteria include milestones within the Settlement Agreement, RCRA permit provisions, the terms of the VCO, and treatment alternatives for both solid high-level and sodium-bearing liquid wastes evaluated in the Idaho High-Level Waste and Facilities Disposition Environmental Impact Statement (DOE 1999b). Cleanups and closures at HLW facilities are accomplished using HWMA/RCRA methods for treatment, storage, and disposal facilities. Buildings are dispositioned under D\&D\&D, while past releases are addressed through ER with HWMA/RCRA factored into the cleanup decision.

\subsubsection{Environmental Restoration Program}

The Environmental Restoration (ER) Program exists to facilitate the remediation of identified release sites and facilities at the INEEL in accordance with CERCLA, including all CERCLA-based applicable requirements, and ultimately achieve removal of the INEEL from the National Priorities List.

The Environmental Restoration Long-Term Stewardship (ERLTS) Project is designed to consolidate planning, management, operations, ground water monitoring, institutional controls, and maintenance under a centralized project to provide an efficient and consistent approach for implementing CERCLA activities. The project will implement and track the requirements defined in the various RODs, and input from regulators and stakeholders. Initially, the project will focus on integration of ER operations and groundwater monitoring responsibilities associated with WAGs 1, 2, 3, 4, 5, 6, 7, and 10 . WAG 8, NRF, and WAG 9, ANL-W, will be integrated in the future as directed by DOE-ID.

The ERLTS Project is a natural outgrowth of ER Operations and WAG 10 projects and activities. WAG 10 is responsible to determine the nature and extent of contamination and associated risks to human health and the environment, INEEL-wide, for waste sites included in the FFA/CO but not considered part of other WAGs, with special emphasis on the Snake River Plain Aquifer (SRPA). WAG 10 addresses Sitewide issues in conjunction with Region 10 of the EPA, IDEQ, and other stakeholders, including the Shoshone-Bannock Tribes, and the general public.

The overall mission for WAG 10 is to:

- Determine the nature and extent of contamination associated with WAGs 6 and 10 sites.

- Determine the current and future risk posed by the contaminants of concern to human health and the environment

- Develop and evaluate candidate remediation technologies

- $\quad$ Develop and implement the appropriate remedial alternatives based on CERCLA criteria.

In 1999, a work plan was prepared for the OU 10-04 comprehensive remedial investigation /feasibility study (RI/FS). This plan served two purposes: (1) to meet the current FFA/CO enforceable 
milestones of identifying and recommending approaches to resolve OU 10-04 data gaps and providing necessary planning and (2) to propose an alternative OU 10-04 RI/FS schedule, to be performed in two phases, the OU 10-04A (the OU 10-04 RI/FS) and the OU 10-04B (the OU 10-08 RI/FS). The final OU 10-04 Comprehensive RI/FS document was transmitted to DOE-ID and the agencies in August 2001.

Sites within the individual WAGs will be transferred to the ERLTS Project, which will provide consolidated monitoring of institutional control sites and sites requiring long-term monitoring and management.

Sites transitioned to the ERLTS Project are those that have completed remediation or only require routine monitoring and sites where ongoing treatments are in place. The program will begin management of remediated sites or no further action sites from other WAGs where long-term monitoring or institutional controls are required. The responsibility for management of sites by the ERLTS Project will generally occur after the first 5-year post-ROD review. At this stage in the project, all remediation is complete, and the only activities remaining are monitoring, maintenance, and reporting. The remaining scope, long-term monitoring, and maintenance activities will be transitioned and managed by the program.

Significant numbers of ER activities are expected to be complete at the INEEL by 2006. Many of the sites may not be cleaned up to a standard allowing unrestricted use and will require monitoring and maintenance to validate and ensure that the actions taken continue to be effective. LTS activities, including soil and groundwater monitoring, recordkeeping, and maintenance of containment structures, must continue long term to ensure the protection of human health and the environment.

The INEEL D\&D\&D Program is generally the last custodian of facilities which will, upon closure, enter the INEEL LTS Program. Facilities being cleaned up and closed or demolished using the processes and requirements of the D\&D\&D Program may contain RCRA/VCO units and may be surrounded by ER operable units, but are also subject to the radiation dose and contamination limits of DOE.

\subsubsection{INEEL LTS Program}

Sites that transition to the ERLTS Project will eventually transition to the INEEL LTS Program. Monitoring and maintenance activities along with reporting responsibilities will become the responsibility of the INEEL LTS Program. Given the recordkeeping procedures and requirements and the level of detail that currently exists for ER sites, the transition to INEEL LTS Program should proceed smoothly. However, at this stage information and data management practices for RCRA closures are not consistent and require further development.

One of the critical aspects of site transition to the INEEL LTS Program is data and information management, and, specifically, the types of information needed for a site to successfully transition to the INEEL LTS Program. This information is required for future non-DOE site stewards, emergency response personnel, and stakeholders to ensure protection of human health and the environment following completion of cleanup. The ERLTS Project currently manages an administrative record (AR) and an information repository (IR) consistent with EPA and DOE requirements. The process for control and inclusion of documents into the administrative record and information repository (AR/IR) is defined in Administrative Record and Information Repository Procedure for Environmental Restoration (INEEL 2000b) Management Control Procedure (MCP)-204, Rev 5, Manual 18. This MCP provides procedures and guidance for project managers on incorporation of ER documents into the AR/IR. 
A listing of the document categories associated with a specific OU (within a WAG) is shown below.

- Site Identification - information and reports that identify the site including background, notification and site inspection reports, preliminary assessments, site investigations, previous OU information, no action sites, and initial assessments.

- Removal Response - sampling and analysis plans, data, chain of custody forms, engineering evaluation/cost analysis approval memoranda, action memoranda and amendments, health and safety plans, work plans, quality assurance plans, and hazard classifications.

- Remedial Investigation - sampling and analysis plans, data, work plans, remedial investigation reports, and investigation reports.

- $\quad$ Feasibility Study — analysis of remedial action objectives and proposed remedial actions.

- $\quad$ State Coordination - interim actions, risk assessments, quality plans, scope of work, field sampling plans, cost analysis, summary reports, health and safety plans, environmental assessments, treatability study, schedules, and decision statements.

- $\quad$ Enforcement-cooperative agreements and requirements.

- Health Assessments - enforcement history, administrative orders, consent decrees, affidavits, notice letters and responses, offsite shipments, and policies.

- Natural Resource Trustees — notices issued, findings of fact, and associated reports.

- $\quad$ Public Participation - comments and responses, community relations plan, public notices, public meeting transcripts, fact sheets and press releases, and responsiveness summaries.

- Technical Sources and Guidance Documents-EPA guidance, technical sources, technical memoranda, and land-use documents.

- $\quad$ EPA and state reviews-EPA and state comments, DOE comment responses, extension requests and approvals, and project management meeting minutes.

\subsubsection{Waste Management Program}

This program is focused on managing waste from previous, current, and all future operations to avoid further contamination that may impact human health, safety, or the environment. The WM Program includes all practices to accomplish waste minimization, treatment, storage, and disposal. The WM Program office, as the larger EM Program, is controlled by five primary agreements, or driversFFA/CO (EPA et al. 1991), INEEL Site Treatment Plan (1995), 1995 Settlement Agreement and Court Order (DOE et al. 1995), Accelerating Cleanup: Paths to Closure (INEEL 1998), and VCO (IDEQ 2000) - and the State of Idaho HWMA/RCRA regime and associated permit provisions. As the WM Program continues to meet agreement milestones and ship waste, LTS program planning will be appropriate for all facilities involved in the treatment, storage, shipment, and disposal. One example of the importance of WM Program involvement in the LTS process exists in the ultimate disposition of the RWMC. In addition to RWMC, the Advanced Mixed Waste Treatment Project (AMWTP) must be included in LTS program planning. Similarly, the WM Program plays an essential role in the identification of specific science and technology needs that must be met to enable or improve the 
accelerated cleanup schedules and associated costs. Consequently, the active participation of the WM Program in LTS planning is essential. Funding for the BBWI Environmental Monitoring Programs is from the INEEL Waste Management Program.

\subsubsection{Spent Nuclear Fuel Program}

The mission of the SNF Program is to safely manage, store, and dispose of DOE-owned SNF at the INEEL by 2035. This ultimate milestone and all interim measures are contained in the Settlement Agreement (DOE et al. 1995). The milestones are being achieved by following a three-part strategy of resolving existing vulnerabilities associated primarily with storage of SNF in outdated underwater storage facilities; preparing and storing INEEL-assigned SNF in consolidated, onsite, interim dry storage facilities; and preparing the SNF for offsite disposal at a monitored retrievable storage facility or federal repository. In the context of LTS planning, the Settlement Agreement milestones and all other regulatory criteria should be assessed, in a process similar to that described for the HLW Program and undertaken by the ER Program to ensure compliant implementation of LTS. The structures and facilities associated with the interim storage of SNF also should be considered in the context of LTS planning for SNF.

\subsection{Environmental Affairs}

The Environmental Affairs Directorate works closely with ER, the other EM programs, and all Sitewide facilities and programs to ensure effective communications on compliance issues. The INEEL Environmental Affairs Directorate will support INEEL LTS Program planning through the assistance it provides line management in fulfilling environmental compliance responsibilities. Environmental Affairs facilitates integration of important Sitewide programs, including CERCLA, RCRA, Clean Air and Water Acts, and the National Environmental Policy Act (NEPA).

\subsection{Environmental Monitoring Program}

The BBWI Environmental Monitoring Program monitors environmental media and facility effluents (INEEL 2000c). The United States Geological Survey, the Stoller Corporation, National Oceanic and Atmospheric Administration, and the INEEL Oversight Program also conduct environmental monitoring.

The primary purposes of monitoring and surveillance are to:

- Demonstrate, provide, and interpret environmental conditions

- $\quad$ Verify compliance with applicable regulations, permits, or standards

- $\quad$ Ensure protection of human health and the environment.

The BBWI Environmental Monitoring Program (EMP) conducts routine compliance monitoring and environmental surveillance at the INEEL. The EMP samples the following media: drinking water, liquid effluents, groundwater, ambient air, surface water/storm water runoff, soils and biota, and direct radiation. The following is a summary of each monitoring program.

- The Drinking Water Program was established to monitor production and drinking water wells, which are multiple-use wells for industrial use, fire safety, and drinking water. The DWP monitors drinking water to ensure it is safe for consumption and to demonstrate that it meets federal and state regulations. The Safe Drinking Water Act establishes the overall requirements for the DWP. 
Currently 10 water systems including 17 wells are monitored at the seven BBWI managed facilities. NRF and ANL are not included in the BBWI DWP.

- $\quad$ The Liquid Effluent Monitoring Program monitors for nonradioactive and radioactive parameters in liquid waste effluents generated within selected facilities at the INEEL. This program ensures that liquid effluent samples provide representative data to demonstrate compliance with permits and regulations. Liquid effluent streams are monitored at the IRC in Idaho Falls, the CFA Sewage Treatment Plant, INTEC Percolation Ponds and Sewage Treatment Plant, TAN/TSF Sewage Treatment Plant, Water Reactor Research Test Facility (WRRTF) process and sewage ponds, and the TRA Cold Waste Pond.

- $\quad$ The Storm Water Monitoring Program meets the Storm Water Industrial Permit requirements by conducting permit-required monitoring. In addition, the program monitors storm water to deep injection wells to comply with State of Idaho Injection Well Permits. Currently 34 sites at five INEEL areas are designated as storm water monitoring locations based upon drainage patterns and proximity to potential sources of pollutants.

- $\quad$ The Groundwater Monitoring Program personnel collect all routine groundwater samples required by the Wastewater Land Application Permits negotiated with the State of Idaho. Monitoring wells were selected based on the hydrogeology of the area to best determine the impact to the subsurface and the Snake River Plain Aquifer by liquid effluent discharges to the percolation ponds.

Currently, four wells are monitored for the INTEC Percolation Ponds, four wells are monitored for the INTEC Sewage Treatment Plant, and four wells are monitored for the TAN/TSF Sewage Treatment Plant.

- The Environmental Surveillance Program monitors air, surface water runoff, soil, biota, and direct radiation to comply with applicable DOE Orders and other requirements. Environmental surveillance is conducted in and around waste management facilities (RWMC, WERF, and TAN) for compliance with DOE Order 435.1. ESP data are used to monitor potential trends in radioactivity in the environment at the INEEL in order to assess possible impact on-Site and offSite. In addition, sulfur dioxide and nitrous oxide are measured in compliance to a State of Idaho negotiated air permit. 


\section{LTS BASELINE INFORMATION BY REGULATORY INTERFACE}

The INEEL LTS Program will be responsible for conducting actions required to maintain and verify that INEEL cleanup missions have resulted in a site condition that is protective of human health and the environment. This will allow the LTS Program to simultaneously comply with numerous regulations, RODs, environmental permits, DOE orders, and consent orders that apply inconsistently to the various units and facilities at a site proposed for INEEL LTS Program transition (proposed INEEL LTS site). The application is inconsistent in that, for example, a given facility within a proposed INEEL LTS site may not be under the same set of regulations or requirements as another facility within the same proposed INEEL LTS site.

\subsection{Environmental Restoration}

The ESP (DOE 1998a) primarily reflected completion of ER activities, i.e., cleanup of sites identified in the FFA/CO and managed under one of the $10 \mathrm{WAGs}$. INEEL LTS sites-ER sites, shown in Appendix C, summarizes the status and plans for sites being cleaned up under the FFA/CO and is based on the ER baseline master schedule for fiscal years 2002 through 2004 (INEEL 2001e). Per the Idaho FFA/CO agreement and the Idaho RCRA permit, all RCRA corrective actions will be addressed under the FFA/CO agreement.

\subsection{RCRA/HMWA Closure}

Hazardous waste units are regulated under the RCRA, as administered by the IDEQ under the HWMA, to ensure that hazardous wastes are disposed of in an environmentally safe manner and those facilities that treat, store, or dispose of hazardous waste do so in a way that protects human health and the environment. Upon deactivation, each hazardous waste management unit must undergo HWMA/RCRA closure. Many units at the INEEL were closed under interim status prior to permitting.

The HWMA/RCRA closure performance standards for "clean closure" are:

- $\quad$ Minimizing the need for further maintenance (40 CFR 265.111[a])

- $\quad$ Controlling, minimizing, or eliminating postclosure escape of hazardous waste, hazardous constituents, leachate, contaminated runoff, or hazardous waste decomposition products to the ground or surface waters or to the atmosphere (40 CFR 265.111[b])

- $\quad$ Removing or decontaminating all waste residues, contaminated containment system components (liners, etc.), contaminated soils, and structures and equipment contaminated with waste and properly managing all hazardous wastes generated during closure activities (40 CFR 265.197[a])

In addition to the standards presented above, a contingent landfill closure and postclosure plan for the proposed INEEL LTS site is required if any contaminated soils cannot be practicably removed or decontaminated or if a site does not have adequate containment. Landfill closure is a last resort if the clean closure performance standards cannot be met. Landfill closure includes stabilizing any remaining hazardous wastes, installing a final cover, and long-term (30-year) monitoring and maintenance.

HWMA/RCRA closure plans do not specifically address radioactive constituents, as these constituents are not regulated by the IDEQ. Radiological activities during closure are regulated under DOE orders and procedures and are not overseen by the IDEQ. Separate or concurrent DOE radiological closure of an HWMA/RCRA-regulated site may be necessary in some cases. 
The data provided for the HWMA/RCRA closures is based on information in the HWMA/RCRA Work Plan for the INEEL (INEEL 2001f) and the Part A Permit Application (DOE 2000). Where available, specific contaminants of concern (COCs) were identified based on review of the HWMA/RCRA closure plans. Where specific COCs were not available, the COCs are identified as those EPA hazardous waste numbers specified in the Part A Permit Application. INEEL LTS sites-RCRA closure sites, shown in Appendix C, summarize the status and schedule for systems to be closed under HWMA/RCRA regulations.

\subsection{Voluntary Consent Order}

In June 2000, IDEQ and DOE-ID entered into a consent order regarding the INEEL. The VCO is a long-term agreement between the State of Idaho and DOE-ID to resolve potential compliance issues with provisions of the HWMA/RCRA at the INEEL.

The VCO includes a Consent Order Action Plan with various "Covered Matters," based on the potential HWMA/RCRA noncompliance, which are being addressed through a series of milestones specified in the action plans. Activities will be conducted under the VCO over the course of the program (through Fiscal Year 2019), which is level funded at \$10 million per year. Each Covered Matter includes the citation, issue description, action summary, and interim actions as negotiated with the IDEQ.

The VCO Action Plan includes the three appendices, which include Covered Matters. Appendix A of the VCO includes Covered Matters with detailed action plans (specific milestones are stated in the action plan, which upon completion result in closeout of the action plan). Appendix B of the VCO includes covered matters with tiered milestones. These action plans generally include initial milestones (e.g., submittal of hazardous waste determination) that, upon review and approval by IDEQ, may initiate development of further milestones and interim action under the VCO, if a continuing regulatory noncompliance is identified. This structure allows the VCO Program to plan and negotiate further milestones with the IDEQ, taking into account available funding. Appendix $\mathrm{C}$ of the VCO includes Covered Matters that are closed.

Funding for VCO activities is based upon established stipulated milestones within the action plans. Those Covered Matters with established milestones are funded before other Covered Matters. Work within the larger Covered Matters, such as SITE-TANK 005 that includes over 799 tanks and related equipment, is prioritized, such that units that pose the greatest risk to human health and the environment are addressed first.

In many cases, the units and sites included in the VCO are part of active systems at the INEEL; many others are part of inactive systems that, upon completion of VCO activities, will transition to other programs at the INEEL (e.g., D\&D\&D). Closeout of items identified in the VCO Action Plan does not necessarily indicate that the units are not, or will not, be regulated under separate regulatory authority. Close integration with other programs may be necessary as the regulatory status of units is determined and further milestones under the VCO are negotiated with the IDEQ and implemented.

Information provided for the VCO is based on the milestones specified in the Action Plan, discussion with work package managers, and current status updates. Items requiring integration and data needs for LTS are preliminary based on the current information available for these action plans. As more data are developed, as part of the VCO activities, additional integration and data needs may become evident. INEEL LTS sites - VCO sites, shown in Appendix C, summarizes the status and plans identified in the VCO. 


\subsubsection{Other Tanks and Units at the INEEL}

The INEEL Tank Inventory Database (TID) was developed by the INEEL to be used to identify and track the regulatory status of tanks at the INEEL. The TID was compiled based on data from facility walk-downs, operational information, and process knowledge. The database provides fields for tracking the regulatory status, operational status, materials of construction, capacity, location, and other items necessary for the identification, inventory, and regulatory status of units at the INEEL.

While the database was originally developed to identify and then track the regulatory status of underground storage tanks (USTs) that were regulated for storage of petroleum or other 40 CFR 280regulated substances, it was later used to identify tanks potentially regulated by RCRA. The TID was later expanded in 1997 to include identification and inventory of all tanks at the INEEL. In early 1998, the TID was again revised, and the VCO identified, established, and tracked milestones for remediation efforts for a number of sites at the INEEL. The VCO program expanded and no longer uses the TID but has created a sister database that feeds data to the TID. This database gathers, catalogs, and tracks different types of data than the TID.

The TID includes a listing of more than 3,500 units across the INEEL that are managed under varying regulatory authorities (e.g., HWMA/RCRA, UST regulations, units where closure is not required, closed units, nonhazardous units, FFA/CO, exempt units, units never placed in service, units removed, units never installed).

The TID contains a listing of active and inactive units at the INEEL. These units include those that have been closed, units covered under the VCO, units undergoing HWMA/RCRA permitting, and other units that may transition into the LTS Program. Particularly useful for transition is the information compiled on units that have no current regulatory compliance issues and are not actively being managed under some regulatory authority.

\subsection{Deactivation, Decontamination, and Decommissioning}

The INEEL D\&D\&D Program is generally the last custodian of facilities that would, upon closure, enter the LTS Program. Facilities being cleaned up and closed or demolished using the processes and requirements of the D\&D\&D Program may contain RCRA/VCO units and may be surrounded by ER operable units, and are also subject to the radiation dose and contamination limits of DOE.

There are many INEEL facilities currently inactive or approaching the end of their usefulness. The D\&D\&D Program has prepared a 10-year plan based on priorities and guidelines established in the INEEL D\&D Long-Range Plan (INEEL 1999) and the Deactivation, Decontamination, and Decommissioning Project Manager's Handbook (INEEL 2001g). The planning horizons of the ER Program and the Waste Management Program may differ by more than 10 years, and even though priorities can be established, the budget cycles contain a large degree of uncertainty. While budget projections are made, increased or decreased funding will significantly impact the schedules currently established. The role of LTS will vary greatly depending on the final D\&D\&D activities. In many cases, contaminants will be left at the facility site with containment and mitigation and, in some cases, facilities undergoing D\&D\&D are scheduled for reuse. The D\&D\&D Program will be responsible for providing necessary data on facilities that have been decommissioned to the INEEL LTS Program. INEEL sitesD\&D\&D Program, shown in Appendix C shows the facilities identified in the 10-year plan. 


\subsection{Cultural and Historical Resources}

Buildings and facilities closed prior to transition to the INEEL LTS Program, other structures, historic objects (i.e., equipment and records), prehistoric and historic archaeological sites and artifacts, and traditional cultural places of importance to the Shoshone-Bannock Tribes and other stakeholders are also subject to the provisions of historical and cultural resource preservation regulations. The INEEL Cultural Resources Management Office manages these resources through application of the INEL Management Plan for Cultural Resources (DOE-ID 1995a). This plan is scheduled to be updated in Fiscal Year 2002 to reflect recent changes to statutory requirements for cultural and historical resource management, most specifically the National Historic Preservation Act, as amended, and the 2001 DOE policy on the management of cultural resources at their facilities. The revised plan is expected to form the basis for a Programmatic Agreement among DOE-ID, the Advisory Council on Historic Preservation (ACHP), and the Idaho State Historic Preservation Office (SHPO). The plan is also expected to be more explicit in describing how INEEL programs can meet the requirements.

A thorough survey of DOE-ID-owned buildings at the INEEL, which are eligible for inclusion on the National Register of Historic Places, has been completed. The list of potentially eligible buildings is presented in Appendix D. However, consultation with the SHPO, ACHP, and other stakeholders regarding the eligibility determinations, methodology used to arrive at these determinations, and proposed mitigation when the resources will be adversely impacted by INEEL projects has not been completed. Inventories of other historically significant INEEL structures and objects have yet to be conducted.

In addition to buildings and other structures and objects, systematic surveys of $7 \%$ of the INEEL have revealed over 1,600 prehistoric archaeological sites. Preliminary predictive modeling suggests an additional 40,000 prehistoric and historic sites remain undiscovered. Artifacts from the INEEL are housed at the Idaho Museum of Natural History, in Pocatello, Idaho. Though the artifacts have been accessioned to the Museum's collections, these artifacts remain the property of DOE in perpetuity, and DOE remains accountable for their proper care. DOE and the INEEL Cultural Resources Management Office continue to work with Native Americans to gain a better understanding of Traditional Cultural Places and sacred sites.

Cultural resource surveys are conducted as part of long-term resource stewardship responsibilities and also when activities are planned that may potentially impact cultural or historic resources. Assessments are then completed to determine if the resource is eligible to the National Register of Historic Places and, if so, whether the planned activity will adversely affect the resource. When it is determined that the activity will have an adverse impact and that such impact cannot be avoided, the SHPO, when necessary, the ACHP, and other stakeholders are consulted to determine appropriate mitigative measures. For example, such measures for historic resources might include the collection and archiving of photographs, drawings, and written documentation to Historic American Engineering Record standards. Agreement documents, in the form of Memoranda of Agreement, which are now in place or completed to date, include:

- $\quad$ Auxiliary Reactor Area (Army Reactor Area)

- $\quad$ Army Reentry Vehicle Facility Site (ARVFS)

- $\quad$ B17-702 Fire Station \#2 Structures

- $\quad$ CF-639 Security Ammunition Bunker

- $\quad$ CF-640 Storage and Sling Tester 
- $\quad$ CF-654 Landlord Craft Operations and Gas-Bottling Storage

- $\quad$ CF-665 Equipment Repair Building

- $\quad$ CPP-601 Fuel Process Building

- $\quad$ CPP-603 Wet and Dry Fuel Storage Facility

- $\quad$ CPP-627 Remote Analytical Facility

- $\quad$ CPP-640 Headend Process Plant

- $\quad$ CPP-648 Sludge Tank Control House

- $\quad$ CPP-633 Waste Calcining Facility

- $\quad$ CPP-631 RALA Off-Gas Cell

- $\quad$ CPP-709 East Side Service Waste Facility

- $\quad$ CPP-734 West Side Service Waste Facility

- $\quad$ Naval Ordnance Test Facility (used during Vietnam War 1968-1970)

- $\quad$ TAN-602 Administration Building Vault

- $\quad$ TAN-629 Specific Manufacturing Capability Assembly Building Hanger

- $\quad$ TRA-666 Hydraulic Test Facility

- $\quad$ TRA-645 ETR Secondary Coolant Pumphouse.

Documentation of mitigation activities, identification of cultural resource management requirements (what still needs to be done by the INEEL LTS Program), compliance with any and all agreement documents, and application of resource mitigation requirements for future LTS activities (to ensure LTS actions do not improperly impact cultural and historic resources) must be completed.

\subsection{INEEL Facility Summary Information}

\subsubsection{Test Area North}

TAN encompasses approximately 41 hectares (102 acres) located in the north-central portion of the INEEL. The area comprises four different facilities: TAN TSF, Initial Engine Test Facility, WRRTF, and SMC Facility/Loss-of-Fluid Test (LOFT) Facility. TAN was originally built between 1954 and 1961 to support the Aircraft Nuclear Propulsion Program sponsored by the U.S. Air Force and Atomic Energy Commission. The program's objectives were to develop and test designs for nuclear-powered aircraft engines. Upon termination of this research in 1961, TAN facilities were converted to support a variety of other DOE research projects. 
4.6.1.1 TAN End States. The projects shown below were major considerations used as the basis for end-state planning in the ILRP (INEEL 2001b).

- OU 1-10 ROD - this ROD (DOE-ID 1999a), summarized previously, identified 10 of the 94 WAG 1 release sites as posing unacceptable risks and were identified in the Long-Range Plan. In addition, 11 "no further action" sites also require institutional controls; thus, a total of 21 sites.

- OU 1-07B ROD - This project requires remediation of the aquifer at TAN, which was finalized in a 1995 ROD (DOE-1995b). The basis of the end-state planning was onsite bioremediation and natural attenuation, which required an amendment to the existing ROD. This proposed action was finalized in an amended ROD in 2001.

- Settlement Agreement (EPA et al. 1995)—no changes to this agreement are noted.

- Ongoing future missions at TAN-The basis of end-state planning are continued existing missions.

\subsubsection{Test Reactor Area}

TRA was established in the early 1950s in the southwestern portion of the INEEL. It has housed extensive facilities for studying the effects of radiation on materials, fuels, and equipment, including high neutron flux nuclear test reactors. HWMA/RCRA hazardous wastes have been generated from scientific and engineering research projects conducted at TRA. Although extracted and treated, the disposed wastes still contained low-level radioactive and RCRA-regulated hazardous solutions.

4.6.2.1 TRA End States. The projects shown below were major considerations used as the basis for the end-state planning in the ILRP (INEEL 2001a). Changes to the project-planning basis are also presented. No major changes to these projects are noted that would cause changes to the end-state plan.

- OU 2-13 ROD-Remedial actions completed in 1997 will continue to be monitored and reviewed.

- Ongoing and Future Missions_-Planning assumed the current missions would continue.

\subsubsection{Idaho Nuclear Technology and Engineering Center}

INTEC began operating in 1952. The primary missions were reprocessing uranium for defense purposes and research and storage of SNF. Irradiated defense nuclear fuels were reprocessed to recover unused uranium. In 1992, the reprocessing mission was phased out. The current INTEC mission is receiving and temporarily storing SNF and processing and storing radioactive wastes for future disposition.

In addition to the mission of reprocessing SNF, INTEC stabilized radioactive high-level liquid waste (HLLW) by converting it into a granular solid, similar in consistency to sand, through a process known as calcination. The process was conducted at the Waste Calcining Facility (WCF). Calcination achieves a significant volume reduction from liquid to solid. After calcination, the calcined solids were transferred to large stainless-steel structures encased in thick concrete vaults (bin sets). In 1982, the New Waste Calcining Facility (NWCF) replaced the WCF. Although processing of nuclear fuel was terminated in 1992, calcination of the HLLW continued until it was completed in February 1998. Sodium-bearing wastes are still being processed. 
4.6.3.1 INTEC End States. The basis for end-state planning included seven major considerations:

1. The environmental impact statement (EIS) for HLW at the INEEL - the final EIS was scheduled to be issued in February 2001 and the ROD by April 2001. However, the draft EIS was issued in December 1999 (DOE 1999b), and the final EIS and ROD remain pending.

2. OU 3-13 ROD (DOE-ID 1999b) - This ROD was signed in 1999 and preparation of the remedial design is ongoing. The ROD requires disposal of contaminated soil at the ICDF. Construction of this facility began in June 2001.

3. OU 3-14 TFF Soils-This investigation is ongoing with the ROD scheduled for 2003

4. The 1995 Settlement Agreement-This agreement specified regulatory milestones to remove SNF from Idaho

5. HWMA/RCRA Part A Application (DOE 2000) - This application includes the TFF and CPP-620. The planning included closure of these tanks.

6. Idaho CERCLA Disposal Facility (ICDF) - This repository is for disposal of contaminated soils from INEEL CERCLA projects. This facility, which began in June 2001, will provide a disposal location for several ER sites and is consistent with RODs from those sites.

7. Mission of INTEC - Significant changes to the mission of receiving and storing SNF and radioactive wastes would cause changes to the facility end state.

\subsubsection{Central Facilities Area}

CFA includes buildings constructed in the 1940s and 1950s to house Navy gunnery range personnel, administration offices, a workshop, and warehouse space. The facilities have been modified over the years to accommodate changing needs. Presently, CFA provides four major types of functional space: crafts, administrative offices, maintenance services, and a laboratory.

4.6.4.1 CFA End States. The end-state planning included six major considerations:

1. OU 4-13 ROD - This project identified three sites at CFA requiring remedial action. These sites were finalized in the ROD in 2001.

2. Industrial Solid Waste Landfill - The planning assumed the capacity of the landfills would be sufficient until the year 2030 .

3. Land Farm - The end-state plan indicated that if the land farm were not expanded, other options for disposal of petroleum-contaminated soil would need to be found.

4. Asbestos landfill-This landfill is expected to have sufficient capacity until the year 2020 .

5. Disposal of the contaminated soils from OU 4-13 - This requires construction and operation of the ICDF. Construction began in June 2001.

6. Mission of CFA-CFA supports ongoing missions throughout the INEEL. 


\subsubsection{Power Burst Facility}

Between the 1950s and 1980s, research activities at the INEEL left behind contaminants that posed risks to human health and the environment. The Auxiliary Reactor Area (ARA) consists of four separate operational areas designated as ARA-I, ARA-II, ARA-III, and ARA-IV. Once known as the Special Power Excursion Test (SPERT) facilities, the Power Burst Facility (PBF) now consists of five separate operational areas: the PBF Control Area, the PBF Reactor Area (SPERT-I), the Waste Engineering Development Facility (WEDF) (SPERT-II), the Waste Experimental Reduction Facility (SPERT-III), and the Mixed Waste Storage Facility. Within the ARA and PBF area, 15 sites will require O\&M activities.

4.6.5.1 ARA/PBF End States. The basis for end-state planning included eight major considerations:

1. OU 5-12 Comprehensive Remedial Action-This project includes all remedial actions for WAG 5. No changes in the remediation design have occurred that will affect the end-state plan.

2. 1995 Settlement Agreement-This agreement affects SNF at the INEEL.

3. No further action sites-Nine of the 54 sites in WAG 5 require institutional controls as part of the remedial actions associated with the OU 5-12 ROD.

4. SNF Storage Facility-The PER-620 Reactor Building is an SNF facility. The SNF will be prepared for removal by 2003 and moved to CPP-603.

5. NEPA EIS for removal of SNF from PER 620 Reactor - Compliance with NEPA is required for removal of SNF.

6. Contaminated Soil Repository at INTEC-Remediation associated with OU 5-12 requires soils to be disposed to the ICDF.

7. Archeological Cultural Resources - Approval is required by the INEEL Cultural Resource Management Office before soils are disturbed.

8. WROC missions - WROC provides for the safe storage and recycling of hazardous, mixed, and industrial wastes.

\subsubsection{Radioactive Waste Management Complex}

The RWMC is located in the southwest corner of the INEEL. The facility is used for disposal of low-level waste (LLW) and storage of TRU waste until the wastes can be sent to a permanent repository. The AMWTF, which will be constructed in 2002, will expand waste operations to include the treatment and preparation of TRU wastes for shipment out of Idaho.

4.6.6.1 RWMC End States. The basis for end-state planning included five major considerations:

1. OU 7-13/14 ROD—This document will define future remedial actions at RWMC.

2. OU 7-10 Stage Interim Work Plan-This project will define future work associated with the Pit 9 Comprehensive Demonstration.

3. 1995 Settlement Agreement - As part of this agreement, treatment of waste stored aboveground at the RWMC requires successful construction, completion, and operation of the AMWTF. 
4. HWMA/RCRA Part B Permitting and Closure Units-All units were identified to be operated or closed under interim status with the exception of three units. These three units must be closed before the RWMC mission can be considered complete.

5. Meeting current program needs for the RWMC depends on funding from DOE-TRU waste storage will continue through 2020, and the disposition of RWMC facilities and structures is planned to continue through 2026.

\subsubsection{Naval Reactors Facility}

The NRF was established in 1949 as a test site for the Naval Nuclear Propulsion Program. The facility supported three naval nuclear reactor prototypes that are now decommissioned or dismantled. The mission of the Expended Core Facility, constructed in 1958, is to receive, inspect, and conduct research on naval reactor fuel.

\subsubsection{Argonne National Laboratory-West}

ANL-W includes three major nuclear reactors. The Transient Reactor Test Facility, built in 1959, was designed for overpower transient fuel tests. The EBR-II reactor is a thermal reactor that went into operation in 1964 and was designed to operate with metallic fuel. The Zero Power Physics Reactor, currently in administrative standby, is large enough to enable core-physics studies of full-scale breeder reactors. Various chemical and radioactive wastes were generated from these reactors and the support facilities at ANL-W.

\subsubsection{INEEL Sitewide Area}

The Sitewide area consists of the largely undeveloped desert within the INEEL boundaries and outside of the facility fences. This area acts as a buffer zone between each of the major facilities and the general public. The area contains utilities, communications, and transport systems that serve the INEEL. The land is also used for environmental research, ecological and archeological preservation, and wildlife grazing.

4.6.9.1 Site-Wide End States. The basis for end state planning included 11 major considerations:

1. OU 10-04 Comprehensive RI/FS - This investigation will review all previous investigations, any non-assessed sites, and evaluate cumulative risk posed by sites within WAGs 6 and 10 .

2. Ordnance integration strategy-This project will develop a cohesive approach to the characterization of ordnance areas and the remediation of unexploded ordnance and explosivecontaminated soils.

3. SRPA - Groundwater responsibilities for WAG 10 include the SRPA, excepting any groundwater contamination plumes from the other WAGs.

4. Containment of the BORAX - In 1996, a removal and containment action was conducted for the reactor building at the site. This action was designed to remove hazardous materials listed under HWMA/RCRA and to leave the site in a safe and stable condition until the final assessment in the OU 10-04 Comprehensive RI/FS. The OU 10-04 ROD will serve as the final decision for this remedial action. 
5. Ecological risk assessment (ERA)-The OU 10-04 project is focused on conducting an ERA for the Sitewide Areas. It will use data from ERAs conducted during the individual WAG comprehensive RI/FS projects.

6. Archeological and cultural resources-Federal law protects resources on federally owned lands. Strategies for the effective management of all sensitive cultural resources have been developed in conjunction with pertinent INEEL programs.

7. Well categorization -Wells used to monitor the SRPA are located within the Sitewide Area. The wells are located inside and outside of the facilities and may be used by facility monitoring programs.

8. National environmental research park-The INEEL is designated as a national environmental research park. The park is an outdoor laboratory for basic and applied ecological research and the study of environmental impacts from the development of nuclear technologies.

9. Long-term ecological studies - The Experimental Field Station has been the site of large-scale ecological and radio-ecological studies. The station is intended to be used for research for many years.

10. Land control-Long-term land use scenarios for the INEEL were developed as part of the ILRP. The analyses used illustrate the type and extent of operations the INEEL and its stakeholders find acceptable. Regardless of the future use of the current INEEL lands, the federal government has the obligation to provide adequate institutional controls to areas that pose a significant health or safety risk to the public and workers. These controls will continue until risks diminish to acceptable levels for intended purposes.

\subsection{Closure Site Summary}

Appendix $\mathrm{C}$ summarize status plans for facilities and release sites to be cleaned up using FFA/CO, HWMA/RCRA, VCO, and D\&D\&D protocols, respectively. One of the functions of this guidance document is to update the information contained in the INEEL ESP. Appendix B presents updated ESP maps, and Appendix E presents current ESP critical path events, assumptions, and issues.

\subsubsection{Entry Schedule}

Available information pertaining to the schedule of proposed LTS units entering the INEEL LTS Program is summarized in Appendix C, Schedule for Entry to LTS. The schedule is based on data compiled from the EM Programs. 


\section{MISSION COMPLETION TRANSITION GUIDANCE}

The interest and concern about LTS emerged in large part from DOE's focus on accelerating site cleanup and improving management of the cleanup program. As cleanup is accelerated at various DOE facilities, the need to prepare and implement postcleanup LTS plans and activities is also accelerated. DOE now considers LTS to be an integral part of decision-making during site remediation; however, little guidance exists as to how and when a proposed site is ready to be transitioned to the INEEL LTS Program. However, transfer of LTS responsibilities may occur only after the site landlord Program Secretarial Office (PSO) and EM agree that the EM mission at the site has been completed and the following conditions are met (Glauthier, T. J., 2000, Department of Energy, to All Departmental Elements, Department of Energy, December 15, 2000, "Long-Term Stewardship Transition to Site Landlord," ES2000-026689):

1. A technical planning document has been developed establishing the current LTS operating baseline and describing the scope and operating costs for future LTS activities.

2. The budget authority and budget target have been transferred to the receiving PSO of the amount equivalent to the operating costs for LTS activities.

3. A formal transfer agreement for the LTS that includes posttransfer responsibilities has been coordinated and signed for each site.

With the notable exception of the INEEL's ER program, INEEL EM programs have not developed processes or criteria upon which proposed sites may be transferred to the INEEL LTS Program. As previously discussed, the ERLTS Project is developing methods by which the other WAGs, whose FFA/CO-mandated cleanup actions have been completed, may transition to stewardship actions.

\subsection{Contingencies}

The National Research Council (2000) recommended that DOE develop and implement effective institutional management plans that:

- $\quad$ Anticipate a range of possible outcomes of cleanup and postremediation strategies and apply uncertainty ranges

- $\quad$ Provide proven cleanup and postremediation strategies - ones not likely to change

- $\quad$ Preserve and communicate information about contaminated sites to future Site users

- Contain appropriate and substantive incentives, including stable long-term funding and access to needed resources

- $\quad$ Encourage citizen oversight of the institutional management process

- Call for scientific, technical, and social research and development, including research and development on contaminant reduction, isolation, and stewardship

- Adapt to changing conditions or unexpected outcomes, enabling follow-through on successive phases of the plan. 


\subsection{LTS Transition Development}

Numerous existing documents and previous examples of facility transfer were investigated for developing transition guidance. The most applicable of these was documentation/examples from, the Grand Junction Project Office, Formerly Utilized Sites Remedial Action Program-Summary Protocol Identification-Characterization-Designation-Remedial Action-Certification (DOE 1986), and Technical Guidance for Reviewing Site Transfer Documents for Long-Term Stewardship (DOE 2001). Additionally, documentation was reviewed from Department of Defense Base Realignment and Closure (BRAC) facility reuse and economic development projects, DOE facility transfers for closure sites (e.g., Mound), NRC license termination regulations, exit strategies for CERCLA, Department of Defense (U.S. Army Corps of Engineers 2001a, 2001b), DOE land-use institutional control policies, and federal natural resource management agency(ies) processes, including the Bureau of Land Management (BLM) and U.S. Forest Service.

The criteria for transfer of a proposed INEEL LTS site at the completion of other EM missions should be flexible enough to allow for a simple or complex site. Transition criteria should also allow the LTS Program to meet its long-term goals of maintaining sites in a condition protective of human health and the environment without significant additional remediation or monetary investment outside those identified at the time of transition. Potential criteria for entry and exit from the INEEL LTS Program may be unit specific (applicable to a particular tank, building, or OU); facility specific (risk or performance based); or for the purpose of capability or ecosystem management (e.g., flood control, roads, power). For long-term stability of completed EM missions (data and structures) and overall success of LTS, transition criteria should not be significantly different whether the transfer is within DOE (one project support office to another) or to or from an outside agency.

The guidance identified in this report represents an initial effort at establishing an exit point from EM programs to the INEEL LTS Program and not an effort to define what the exact end state will be for the entire INEEL. These criteria stem from various existing guidance including, Developing Exit Strategies for Environmental Restoration Projects (EPA 2000), and numerous other documents listed in the references (see Section 7). Several other land transfer and transition examples, many having environmental legacies from past land uses, and LTS examples were also investigated for application to development of the generic criteria discussed below:

- Transfer of other federal lands (non-DOE examples such as the Department of Defense BRAC [DOD 1998] to other agencies or the private sector)

- $\quad$ Transfer of Formerly Utilized Sites Remedial Action Program (FUSRAP) sites from the Army Corps of Engineers to DOE (U.S. Army Corps of Engineers 1999)

- $\quad$ Experience gained by DOE in managing remediated uranium mill tailings sites

- BLM withdrawal termination.

\subsection{Transition Guidance}

Transition of sites to the INEEL LTS Program is negotiated between the applicable EM Programs and the INEEL LTS Program. Because multiple EM programs are likely represented within any given proposed INEEL LTS site, these negotiations are expected to occur at an INEEL EM level. As a basis for initiation of transition negotiations, the basic types of criteria that must be satisfied prior to transfer include: 
- Regulatory - Statutory/regulatory-based requirements for cleanup and long-term performance

- Infrastructure-Infrastructure such as caps, wells, roads, equipment, etc., necessary to conduct LTS activities

- Records - Data and information of sufficient type and condition for LTS activities to continue

- Unique expertise or training required to conduct long-term operations

- $\quad$ Project planning, scope, schedule, and budget - A defined project scope, schedule of LTS activities, and budget based on cost estimates

- Interface agreements to define responsibilities before and during transition, and after transition in the event a particular remedy fails or new releases occur from the unit.

The transition of a proposed INEEL LTS site will be accomplished using a formal process that will allow for review of documents, data, and information and onsite inspection of sites. Below are specific criteria under each of these categories.

\subsubsection{Proposed INEEL LTS Sites}

The size and scope of any proposed INEEL LTS site depends on multiple technical, regulatory, economic, social, and political factors. A proposed INEEL LTS site may include facilities or media being cleaned up under CERCLA, RCRA, D\&D\&D, underground storage tank, or other regulations. It is assumed that the size and scope of the proposed INEEL LTS site will be based on negotiations between the INEEL programs involved. While some sites may have completed parts of their cleanup mission, other areas within that site may not be ready for transfer to the INEEL LTS Program. This could be the result of cost efficiencies, budget considerations, incomplete records, regulatory issues, and poor condition of equipment or facilities.

\subsubsection{Regulatory-Based Transition Guidance}

Regulatory transition criteria are concerned with meeting requirements of the FFA/CO, NON/CO, VCO, Settlement Agreement, Site Treatment Plan, and other statutorily based environmental compliance agreements. These are the nuts-and-bolts requirements for completion of the EM mission and include items identified in the Code of Federal Regulations and DOE orders used to meet Atomic Energy Act obligations (e.g., DOE Order 435.1 and 5400.5). Examples of regulatory-based transition criteria are listed below.

- $\quad$ For CERCLA sites, results of the last 5-year review indicate that the remedial action meets the requirements of the O\& M Plan, IC Plan, or ROD. Example: The ROD requires that contaminant concentrations follow a given trend or are below given levels. The site may be transferred to LTS if monitoring data indicate that these requirements are met and an institutional control plan is in place. If these data indicate the requirement is not met, the site will be retained by the ERLTS Project.

- For RCRA closure sites, results from a review of project data and information indicate that the site meets postclosure requirements.

- For RCRA closure sites where waste remains, a postclosure plan has been approved, a survey plat recorded, and the county notified of volumes and types of waste. 
- $\quad$ Management plans are current and have required regulator approvals. Management plans may include sampling plans, quality assurance and quality control (QA/QC) plans, and monitoring plans.

- The conditions under which responsibility for a transferred site to the INEEL LTS Program would be returned to the original EM Program. Example: Detection monitoring or subsequent compliance monitoring (if needed) for units closed under RCRA/HWMA conducted by the INEEL LTS Program may indicate that the site does not meet performance standards and further cleanup may be required.

- The performance assessment and composite analysis requirements of DOE Order 435.1 are met.

- Title, deeds, property transfer documentation, any deed restrictions or covenants that may need to be put in place prior to transition.

- $\quad$ The proposed LTS program is within the scope of approved NEPA documentation.

\subsubsection{Infrastructure Needs Transition Guidance}

The following criteria focus on ensuring that the physical facilities associated with the proposed INEEL LTS site are in operable condition to conduct required LTS activities. The primary emphasis associated with these criteria is that the condition of infrastructure is sufficient to allow smooth transition of the proposed site without additional financial investment by the INEEL LTS Program.

- All required physical and administrative institutional controls are in good condition. Administrative controls may include rights-of-way, legal permission, etc. Physical institutional controls may include fences, signs, monuments, and other onsite engineered features to secure access to LTS sites.

- $\quad$ All access and required utilities have been maintained for the site.

- $\quad$ Perched water or aquifer monitoring wells, onsite monitoring equipment, and ancillary equipment are in good condition. Monitoring data and maintenance records have been reviewed to determine the condition of the wells, and procedures are in place for conducting maintenance and monitoring performance of the equipment.

- $\quad$ Any leachate collection system, monitoring equipment, and ancillary equipment are in good condition. Review of leachate monitoring data indicates the system is functioning as designed.

- Groundwater remediation equipment such as pump and treat or long-term treatment equipment is appropriately operational, maintained, and monitored.

- $\quad$ Engineered caps or covers are in good condition. Monitoring data or the results of 5-year reviews indicate that the cap is performing in accordance with closure requirements or the ROD.

- $\quad$ Physical site boundaries have been located and are consistent with the legal description recorded with county authorities and required deed restrictions.

- $\quad$ Radioactive waste management safeguards are in place in accordance with DOE Order 435.1. 


\subsubsection{Records}

It is assumed that no additional analytical data will be collected to complete transition of a proposed INEEL LTS site. Rather, data collected at a proposed site to fulfill regulatory agreements is sufficient, assuming QA/QC requirements have been met and regulatory approval granted. It is also assumed that approved documentation (by regulatory authorities) is sufficient for transition. These criteria primarily emphasize the availability, accessibility, and retrievability of data and information. Also, the proposed criteria are intended to apply to all cleanup sites (CERCLA, RCRA, D\&D\&D, etc.) and the types of data and information that may be similar in scope and content that are necessary for LTS transition.

- $\quad$ The ER IR contains all pre- and post-ROD CERCLA documentation and monitoring data so that documentation to support LTS can be retained.

- $\quad$ Project files contain RCRA documentation and/or post-ROD CERCLA documentation, as appropriate, and current management plans (i.e., sampling, QA/QC, monitoring plans, etc.) and final D\&D reports.

- Monitoring data and maintenance records have been reviewed to determine the condition of the wells, and procedures are in place for conducting maintenance and monitoring performance of the equipment.

- $\quad$ All media monitoring data and corresponding records are present and readily accessible.

- Data and information necessary for LTS is identified, documented, and the data types are defined. A review of these data is conducted to confirm retrievability and accessibility, and procedures exist to collect the required data.

- Data are in a format that can be incorporated into the INEEL LTS Program.

- All reporting requirements and expectations are communicated between applicable programs, other government agencies, and stakeholders.

- Institutional control requirements are incorporated into the Comprehensive Facility Land-Use Plan, if required.

- Site documentation and project files present the residual contaminant source term, contaminant concentrations, location, and potential risks to human health and the environment.

- $\quad$ Site documentation and project files contain current as-built drawings of surface and subsurface site features, residual waste locations, engineered features, monitoring wells, access, power, and physical institutional controls.

- $\quad$ Required land-use restrictions are properly recorded, i.e., county court house or other agencies.

- Historical and archeological resources at or near the site are located and documented in accordance with federal and state statutes and INEEL policy.

- $\quad$ Ecological concerns that may require modification of LTS activities are documented. 
- $\quad$ Safety analysis reports, emergency preparedness documents, modifications, and emergency management plans.

\subsubsection{Scope, Schedule, and Budget}

The primary emphases associated with these criteria are scope, schedule, and budget plans developed to meet budgeting requirements at the time of transition. The types of information listed below should contain sufficient detail to allow for incorporation directly into a project baseline summary document.

- The scope, schedule, and estimated cost for future management of the proposed LTS project, including any postdesign-life requirements, are defined.

- $\quad$ LTS transition is expected to be a negotiated process between the INEEL LTS Program and the EM Program. As part of this process, the parties should develop a transition schedule. The schedule should include adequate review periods for documentation, site inspections, and development of any additional documentation.

- The basis for transition is included in the description of the proposed INEEL LTS site scope. The basis for transition should include an evaluation of regulatory drivers and specific project requirements.

- Identification of critical resources and personnel required to accomplish tasks for the project after transition takes place.

- A listing of baseline changes that have been approved or any new contracts or modifications necessary before transition takes place.

- Uncertainties and assumptions associated with cleanup and management of the proposed INEEL LTS site should be identified. Uncertainties and assumptions should be a significant part of any LTS management plans.

- Inherent in the LTS transition process is the expectation that a proposed INEEL LTS site will continue to perform as designed over the design-life period. Cost estimates should incorporate detail on the design life of all elements, such as structures, equipment, and fencing, that will require replacement, repair, and maintenance. The estimated cost and schedule should be integrated to give a long-term financial picture of these elements.

- $\quad$ The proposed INEEL LTS site scope is consistent with regulatory requirements (post-ROD monitoring plans, postclosure plans, etc.).

- Before the proposed INEEL LTS site is incorporated into the INEEL LTS, an evaluation of management plans is performed to ensure that the additional scope can be efficiently integrated.

- $\quad$ Future funding mechanisms or programs where outyear funds have been requested, e.g., National Nuclear Security Agency, are identified.

\subsubsection{Special Conditions}

Conditions such as the presence of historical, cultural, archeological, and ecological resources at the INEEL may require unique actions by the LTS program: 
- $\quad$ Primary and secondary site management contracts may need to consider unique programmatic or performance requirements for LTS programs.

- Any special historical or cultural/archeological resources are identified and documented and any reviews required of the condition of historical or cultural resources under stewardship.

- $\quad$ Those requiring special management activities are to be included in the scope and cost estimates.

- $\quad$ Any special ecological concerns such as management of threatened or endangered species are included in the scope and cost estimates.

- $\quad$ Special management conditions for sites within flood-prone areas are documented and incorporated into management plans. Storm water requirements are incorporated in LTS management plans.

- $\quad$ The basis for INEEL LTS site transition is clearly presented to stakeholders, who have the opportunity for review and comment before decisions are finalized. Issues raised by stakeholders are formally addressed and incorporated into LTS transition scope as practicable.

- $\quad$ The performance required, if applicable, which when satisfied may no longer require stewardship oversight and monitoring, and the site can exit the LTS program.

\subsubsection{Identification of Long-Term Stewardship National Program Transition Guidance}

Table 2, "Checklist for Transition to Long Term Stewardship" can be used to establish the criteria for transition of a site the INEEL LTS Program. In addition, Appendix F contains a table on data, information, and documents that may be required as sites, regulated units, equipment, and engineered structures complete cleanup and become candidates for transition to the INEEL LTS Program. The information in the table is designed for, and aids in, drafting local stewardship procedures and criteria.

Insert table 2 here 


\section{FUTURE DEVELOPMENT OF TRANSITION CRITERIA}

- Local procedures for transition of the proposed site to the LTS Program should be developed in conjunction with all EM applicable programs, e.g., Environmental Restoration, Waste Management, and High-Level Waste. The proposed criteria in Section 5 are based on the assumption that specific processes or procedures will be put in place that guide project managers in preparing for transition of a proposed site to the INEEL LTS Program. At a minimum, the following must be performed.

- A technical planning document must be developed establishing the current LTS operating baseline and describing the scope and operating costs for future LTS activities

- The budget authority and budget target have been transferred to the receiving PSO of the amount equivalent to the operating costs for LTS activities

- A formal transfer agreement for the LTS, that includes post transfer responsibilities, has been coordinated and signed for each site.

- The current processes for information storage and retrieval in all EM programs should be researched as a basis for procedure development of data and information repositories. As stated previously, one of the critical issues with the INEEL LTS Program is data and information management. This issue will be crucial to smooth transition and future management of a proposed LTS site.

- The Environmental Restoration Program must manage data and information associated with cleanup and post-ROD management. Procedures, guidance, and records generated and written at the project management level will allow for efficient retrieval of project documentation.

- The D\&D\&D Program should maintain records of all project plans and schedules. These plans should show the interaction of the project with Environmental Restoration, Waste Management and the Site Landlord Programs.

- Site Landlord/Infrastructure Programs should maintain records of all projected land-use planning and infrastructure requirements for all facilities. All land-use and facility plan schedules should be retrievable by future stewards.

- The Waste Management Programs (HLW and LLW) must have all RCRA closure documentation to include postclosure permits and clean closure documentation and all existing permits prior to RCRA closure or transition of operating equipment required for closure.

- $\quad$ Guidance will be developed for LTS cost estimates. It is generally recognized that cost estimates for projects with life cycles many years or decades into the future may require unique assumptions that are not normally used in shorter-term estimates. Estimates for proposed INEEL LTS sites should also be standardized and consistent so that opportunities for long-term cost savings and duplicate cost reductions can be identified.

- Guidance will be developed on assessing the condition of physical assets (i.e., monitoring wells, caps, fences) associated with proposed INEEL LTS sites. For example, there are a large number of monitoring wells at the INEEL. As units are proposed for transition to the INEEL LTS Program, 
an evaluation would likely be conducted to determine the useful life of the wells in addition to replacement costs, which could be incorporated into LTS cost estimates.

- As a first step in the development of transition processes, a pilot test on a site that is expected to be part of the INEEL LTS Program will be conducted and the results evaluated. The above-proposed criteria would be used to evaluate the site and to determine whether procedures currently in place are adequate to provide a smooth transition of project data and information.

These guidance steps will assist the U.S. Department of Idaho Operations Office in: (a) ensuring that the long-term stewardship program leads transition planning with respect to facility and site area end-states, and (b) describing the classes and types of criteria and data required to initiate transition for areas and sites where the facility mission has ended and cleanup is complete. 


\section{REFERENCES}

DOD, 1998, Environmental Cleanup, Base Realignment and Closure (BRAC), A Guide to Establishing Institutional Controls at Closing Military Installations, http://www.dtic.mil/envirodod/brac/icguide.html, Web page researched February 27, 2001.

DOE, 2001a, A Report to Congress on Long-Term Stewardship, Volume I-Summary Report and Volume II - Site Summaries, DOE/EM-0563, U.S. Department of Energy, Office of Environmental Management, Office of Long-Term Stewardship, January.

DOE, 2000, HWMA/RCRA Part A Permit Application for the Idaho National Engineering and Environmental Laboratory, DOE/ID-10213, Rev. 22, Department of Energy Idaho Operations Office, Idaho Falls, Idaho, January.

DOE, 1999a, From Cleanup to Stewardship, A Companion Report to Accelerating Cleanup: Paths to Closure and Background Information to Support the Scoping Process Required for the 1998 PEIS Settlement Study, DOE/EM-0466, Department of Energy Office of Environmental Management, October.

DOE, 1999b, Idaho High-Level Waste \& Facilities Disposition Draft Environmental Impact Statement, DOE/EIS-0287D, U.S. Department of Energy Idaho Operations Office, Idaho Falls, Idaho, December.

DOE, 1998a, Environmental Management End-State Planning Document (Idaho National Environmental and Engineering Laboratory), INEEL/EXT-98-00862, Lockheed Martin Idaho Technologies Company, Idaho Falls, Idaho, September.

DOE, 1998b, Annual Update, Idaho National Engineering and Environmental Laboratory Site Treatment Plan, Rev, 8., U.S. Department of Energy Idaho Operations Office, Idaho Falls, Idaho, October 31.

DOE, 1986, Formerly Utilized Sites Remedial Action Program-Summary Protocol IdentificationCharacterization-Designation-Remedial Action-Certification, U.S. Department of Energy, Office of Nuclear Energy division of Facility and Site Decommissioning Projects, January.

DOE, 1994, Record of Decision: Declaration for PAD-A at the Radioactive Waste Management Complex Subsurface Disposal Area, U.S. Department of Energy Idaho Operations Office, Idaho Falls, Idaho, February.

DOE, Department of the Navy, State of Idaho, 1995, Settlement Agreement to Public Service Co. of Colorado v. Batt, No. CV 91-0035-S-EJL (D. Id.) and United States v. Batt, No. CV-91-0065-S-EJL (D. Id.), October 16.

DOE-ID, 2001, HWMA Closure Plan for the Calciner System in the New Waste Calcining Facility at the Idaho National Engineering and Environmental Laboratory, DOE/ID-10801, U.S. Department of Energy Idaho Operations Office, Idaho Falls, Idaho, August

DOE-ID, 2000a, Institutional Control Plan for the Idaho Nuclear Technology and Engineering Center, Waste Area Group 3, Operable Unit 3-13, DOE/ID-10729, Revision 0, U.S. Department of Energy Idaho Operations Office, Idaho Falls, Idaho, May. 
DOE-ID, 2000b, Record of Decision, Power Burst Facility and Auxiliary Reactor Area, DOE/ID-10700, U.S. Department of Energy Idaho Operations Office, Idaho Falls, Idaho, January.

DOE-ID, 1999a, Final Record of Decision for Test Area North, Operable Unit 1-10, Rev. 0, DOE/ID-10682, U.S. Department of Energy Idaho Operations Office, Idaho Falls, Idaho, October.

DOE-ID, 1999b, Final Record of Decision Idaho Nuclear Technology and Engineering Center Operable Unit 3-13, DOE/ID-10660, U.S. Department of Energy Idaho Operations Office, Idaho Falls, Idaho, October.

DOE-ID, 1999c, Waste Area Group 5 Operable Unit 5-12 Comprehensive Remedial Investigation/Feasibility Study, DOE/ID-10607, U.S. Department of Energy Idaho Operations Office, Idaho Falls, Idaho, January.

DOE-ID, 1998d, Final Record of Decision: Naval Reactors Facility, Operable Unit 8-08, Idaho National Engineering and Environmental Laboratory, DOE/ID-10544, U.S. Department of Energy, Idaho Operations Office; U.S. Environmental Protection Agency, Region 10; Idaho Department of Health and Welfare, September 30.

DOE-ID, 1997a, Idaho National Engineering and Environmental Laboratory Comprehensive Facility and Land-Use Plan, DOE-ID-10514, U.S. Department of Energy Idaho Operations Office, Idaho Falls, Idaho, December.

DOE-ID, 1997b, Final Record of Decision for Test Reactor Area for Operable Unit 2-13 at the Idaho National Engineering Laboratory, DOE/ID-10586, U.S. Department of Energy Idaho Operations Office, Idaho Falls, Idaho, December.

DOE-ID, 1996, author M. R. Arenaz, to the Advisory Council on Historic Preservation, "Signature sheet for the foregoing Memorandum of Agreement Among the United States Department of Energy and the Idaho State Historic Preservation Office covering deactivation work and RCRA closure at the INEL CPP-633 building," U.S. Department of Energy Idaho Operations Office, Idaho Falls, Idaho, September 12.

DOE-ID, 1995a, Idaho National Engineering Laboratory Management Plan for Cultural Resources (Final Draft), DOE/ID-10361, Revision 1, Idaho National Engineering Laboratory, Lockheed Idaho Technologies Company, July.

DOE-ID, 1995b, Record of Decision, Declaration for the Technical Support Facility Injection Well (TSF-05) and Surrounding Groundwater Contamination (TSF-23) and Miscellaneous No Action Sites Final Remedial Action, Operable Unit OU 1-07B, Waste Area Group 1, U.S. Department of Energy Idaho Operations Office; EPA, Region 10; Idaho Department of Health and Welfare, August 1.

DOE-ID, 1995, Record of Decision for Central Facilities Area Landfills I, II, and III, Operable Unit 4-12 and No Action Sites (OU 4-13), DOE/ID-10146, U.S. Department of Energy Idaho Operations Office, Idaho Falls, Idaho, October.

DOE-OR, 2001, Weldon Spring Site Stewardship Document for Operations and Maintenance, DOE-OR-21548-771, Revision 1, U.S. Department of Energy Oak Ridge Operations Office, Oak Ridge, Tenn., July. 
EPA, DOE, State of Idaho, 1991, Federal Facility Agreement and Consent Order and Action Plan, U.S. Department of Energy Idaho Operations Office; Idaho Department of Health and Welfare, Division of Environmental Quality; EPA, Region 10, August 18.

Glauthier, T. J., 2000, DOE, to All Departmental Elements, Department of Energy, "Long-Term Stewardship Transition to Site Landlord,” ES2000-026689, December 15.

House of Representatives, 1999, National Defense Authorization Act for Fiscal Year 2000 Conference Report--to Accompany S. 1059, Report 106-301, August 6.

Huntoon, Carolyn L., 2001, Department of Energy Environmental Management, to Distribution, "Long-Term Stewardship Responsibility," January 19.

IDEQ, 2000, B. R. Monson, IDEQ, to D. N. Rasch, DOE-ID, Enclosure: “Consent Order,” Idaho Code 39-4413, June 14.

IDHW, 1992, Consent Order to the Notice of Noncompliance, U.S. Department of Energy Idaho Operations Office; Idaho Department of Health and Welfare, Division of Environmental Quality; EPA, Region 10, April 18.

INEEL, 2001a, Long-Term Stewardship Draft Technical Baseline, INEEL/EXT-2001-01133, Idaho National Engineering and Environmental Laboratory, Bechtel BWXT Idaho, LLC, Idaho Falls, Idaho, September 28.

INEEL, 2001b, Idaho National Engineering and Environmental Laboratory Infrastructure Long-Range Plan (draft), INEEL/EXT-2000-01052, Idaho National Engineering and Environmental Laboratory, Bechtel BWXT Idaho, LLC, Idaho Falls, Idaho, February.

INEEL, 2001d, DRAFT Environmental Restoration Long-Term Stewardship Program Plan, INEEL/EXT2000-01108, Rev. B, Idaho National Engineering and Environmental Laboratory, Bechtel BWXT Idaho, LLC, Idaho Falls, Idaho, February.

INEEL, 2001e, Environmental Restoration Master Schedule, Rev. B, Idaho National Engineering and Environmental Laboratory, Bechtel BWXT Idaho, LLC, Idaho Falls, Idaho, January 31.

INEEL, 2001f, Hazardous Waste Management Act/Resource Conservation and Recovery Act (HWMA/RCRA) Work Plan for the Idaho National Engineering and Environmental Laboratory (INEEL), EPA No. ID4890008952, Environmental Affairs, Idaho National Engineering and Environmental Laboratory, Bechtel BWXT Idaho, LLC, Idaho Falls, Idaho, April.

INEEL, 2001g, Deactivation, Decontamination, and Decommissioning Project Manager's Handbook, INEL-94/0229, Revision 4, Idaho National Engineering and Environmental Laboratory, Bechtel BWXT Idaho, LLC, Idaho Falls, Idaho, June.

INEEL, 2000a, FY 2001-2005 INEEL Institutional Plan, INEEL/EXT-2000-00462, Idaho National Engineering and Environmental Laboratory, Bechtel BWXT Idaho, LLC, Idaho Falls, Idaho, August.

INEEL, 2000b, “Administrative Record/Information Repository Procedure,” MCP-204, Rev. 5, Manual 18, Idaho National Engineering and Environmental Laboratory, Bechtel BWXT Idaho, LLC, Idaho Falls, Idaho, August 1. 
INEEL, 2000c, Environmental Monitoring Program Report, INEEL/EXT-12000-00318, Idaho National Engineering and Environmental Laboratory, Bechtel BWXT Idaho, LLC, Idaho Falls, Idaho, September.

INEEL, 2000c, INEEL Decontamination and Demolition 10-Year Plan, EXT-2000-01521, Revision 1, Idaho National Engineering and Environmental Laboratory, Bechtel BWXT Idaho, LLC, Idaho Falls, Idaho.

INEEL, 1999, INEEL D\&D Long-Range Plan, INEEL/95-0453, Revision 11, Idaho National Engineering and Environmental Laboratory, Bechtel BWXT Idaho, LLC, Idaho Falls, Idaho, October.

INEEL, 1998, Accelerating Cleanup: Paths to Closure, PLN-177, Idaho National Engineering and Environmental Laboratory, Lockheed Martin Idaho Technologies Company, Idaho Falls, Idaho, February.

INEL, 1994, Record of Decision for Organic Contamination in the Vadose Zone, (OCVZ) RWMC, INEL, Idaho National Engineering Laboratory, Idaho Falls, Idaho, December.

National Research Council, 2000, Long-Term Institutional Management of U.S. Department of Energy Legacy Waste Sites, National Academy Press.

USACE, 2001a, Formerly Utilized Sites Remedial Action Program (FUSRAP) USACE/DOE Transmittal Procedures Draft, U.S. Army Corps of Engineers, Washington, D.C., April 26.

USACE, 2001b, Land-Use Control Guidance for Formerly Utilized Sites Remedial Action Program (FUSRAP) Revised Draft, U.S. Army Corps of Engineers, Washington, D.C., April 26.

USACE, 1999, Memorandum of Understanding, Regarding Program Administration and Execution of the Formerly Utilized Sites Remedial Action Program (FUSRAP), U.S. Department of Energy and U.S. Army Corps of Engineers, March. 
Appendix A

LTS Bibliography 
A-2 


\section{Appendix A}

\section{LTS Bibliography}

The following references were used in determining transition criteria for long-term stewardship

(LTS) at the Idaho National Engineering and Environmental Laboratory (INEEL).

ASTSWMO, 2001, Federal Facility Managers Symposium, Meeting Agenda and Notes: Environmental Challenges at Federal Facilities: Past, Present, and Future, June 18.

DOE, 2001, EM HQ Programs, Planning and Execution, and Laws and Regulations, http://www.em.doe.gov/index4.html, U.S Department of Energy Office of Environmental Management, Home page updated July 24, Web page visited August 14, 2001.

DOE, 2001, Environmental Quality, and Stewardship, http://www.inel.gov/xweb/other/framed.shtml?http://www.energy.gov, U.S Department of Energy Office of Environmental Management, Web page researched August 16.

DOE, 2001, Long-Term Stewardship, Issue 1, Volume 1, Long-Term Stewardship Program INEEL, U.S. Department of Energy, July.

DOE, 2001, Long-Term Stewardship Case Study Report, Office of Long-Term Stewardship Office of Environmental Management U.S. Department of Energy, Washington, D.C., Final Draft, June.

DOE, 2001, Interim Policy for the Department of Energy's Use of Institutional Controls Draft, U.S. Department of Energy, January.

DOD, 2001, Using Environmental Insurance in DoD Property Transfers: A New Tool for Managing Cleanup Risk, BRAC Environmental Program Fact Sheet, Office of the Deputy under Secretary of Defense (Environmental Security), April.

DOE, 1999, Long-Term Surveillance and Maintenance Program Plan, GJO-99-93-TAR, U.S. Department of Energy Grand Junction Office, Grand Junction, Colorado, June.

DOE, 1999, Office of EPA (EH-41), to Distribution, DOE, EPA Guidance on Transfer of Federal Property Undergoing CERCLA Remedial Action, DOE F 1325.8(8-89), October 18.

DOE-EA, 2000, Final, Environmental Assessment for the Transfer of the Department of Energy Grand Junction Office to Non-DOE Ownership, DOE/EA-1338, U.S. Department of Energy Grand Junction Office, Grand Junction, Colorado, April.

DOE-EM, 2000, "Status Report on Paths to Closure," Accelerating Cleanup: Paths to Closure, DOE/EM-0362, February 1998, U.S. Department of Energy Office of Environmental Management, March.

DOE-NV, 2000, Environmental Restoration-Offsites: Salmon Site, Mississippi, U.S. Department of Energy Nevada Operations Office, Office of Public Affairs and Information, DOE-NV-589, January. 
Edge, Russel Pavelka-Zarkesh, Document Systems for Site Stewardship at the U.S. Department of Energy Grand Junction Office, MACTEC Environmental Restoration Services, U.S. Department of Energy Grand Junction Office, Grand Junction, Colorado.

English, C. Joseph, and Jeffery Short, Presentation: Estimating the Cost of Long-Term Stewardship of Environmental Restoration Sites, Project Performance Corporation.

Environmental Law Institute, 2001, The Role of Local Government in Long-Term Stewardship at DOE Facilities, Washington, D.C., Environmental Law Institute, 166 pages.

INEEL, 2001, Environmental Management and Environmental Stewardship, http://www.inel.gov/, Idaho National Engineering and Environmental Laboratory, Home page updated July 27, Web page visited August 13, 2001.

Office of the Under Secretary of Defense, DOD, to Assistant Secretaries of the Army, Navy, Air Force, and Deputy Under Secretaries of Defense-Environmental Security, Industrial Affairs and Installations, and Director, Defense Logistics Agency, July 25, 1997, "Responsibility for Additional Environmental Cleanup after Transfer of Real Property."

Phillippe, CA, Stan, ASTSWMO Federal Facilities Subcommittee, letter to Pat Rivers, ACOE HQ, Environmental Division CEMP-R, and David Geiser, Office of Long-Term Stewardship, Department of Energy, April 13, 2001.

Quale, Ted, 2001, Presentation: Mound Long-Term Stewardship Initiative, BWXT of Miamisburg, Ohio, August 1.

Smith, P. J., 2001, Idaho National Engineering and Environmental Laboratory Long-Term Stewardship Program Strategic Overview, Revision 0, July 11.

Starck, Robert A., DOE Idaho, to Ms. J. M. Crisler, Advisory Council on Historic Preservation, July 26, 2001, "Memorandum of Agreement for the Proposed Dismantlement of Historic Idaho National Engineering and Environmental Laboratory Properties (TS-ETSD-01-146)." 
Appendix B

INEEL Facilities End-State Plan Maps 
B-2 


\section{Appendix B \\ INEEL Facilities End-State Plan Maps}
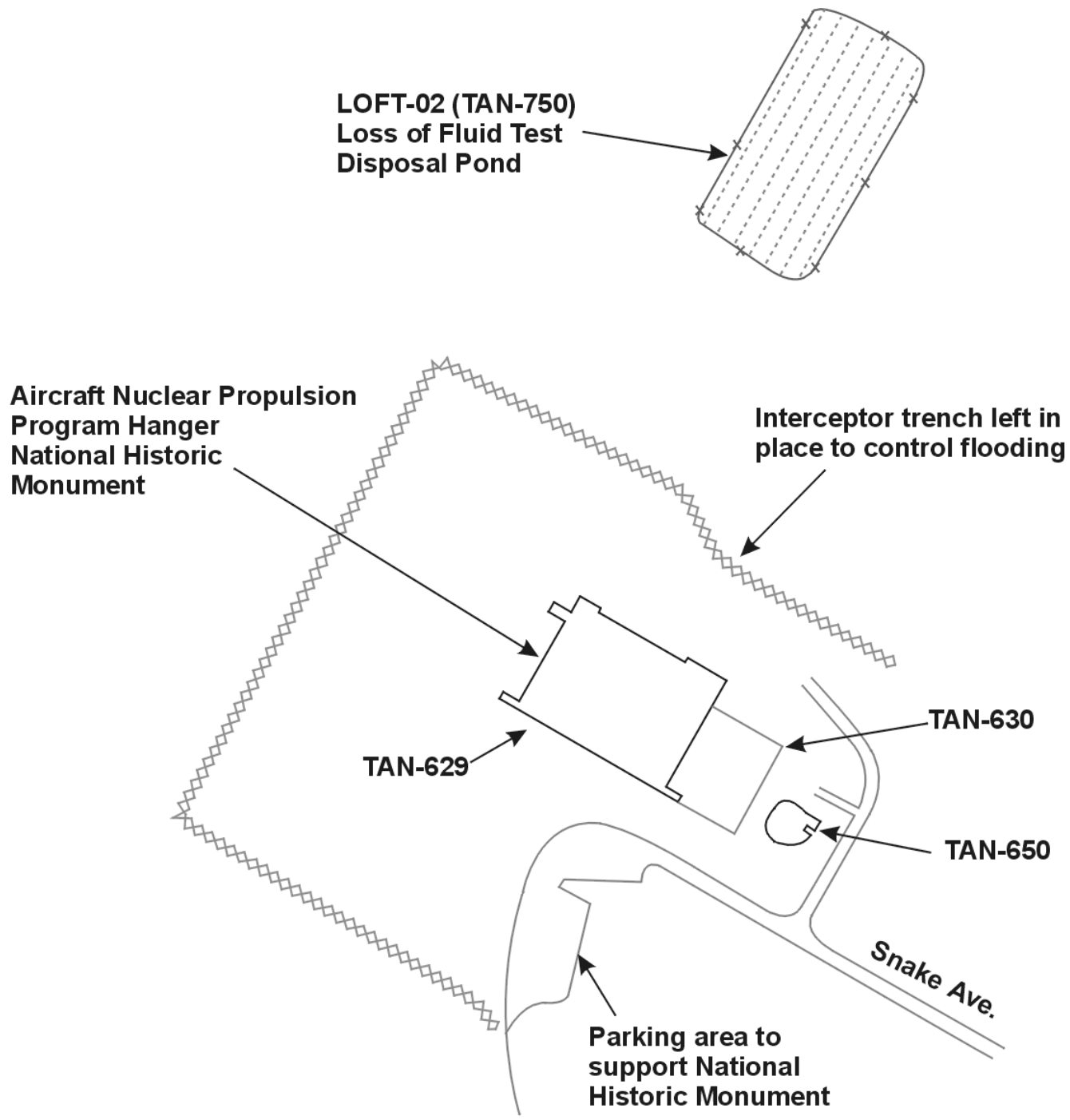

Legend

Fence

Engineered

Soil Cap

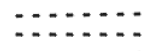

Public Warning

Monument

Figure B-1. INEEL Contained Test Facility end-state plan map. 


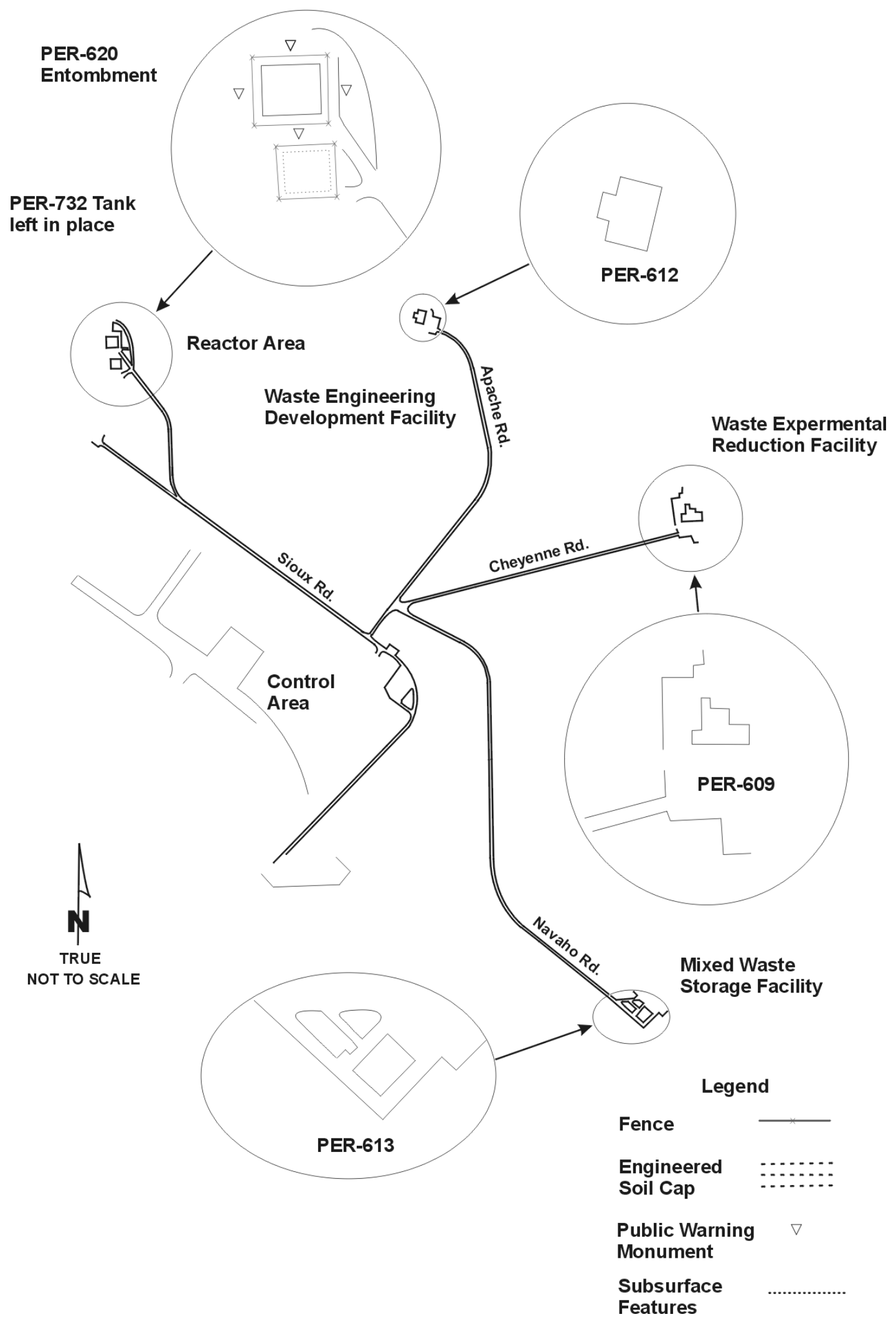

Figure B-2. INEEL Waste Reduction Operations Complex end-state plan map. 


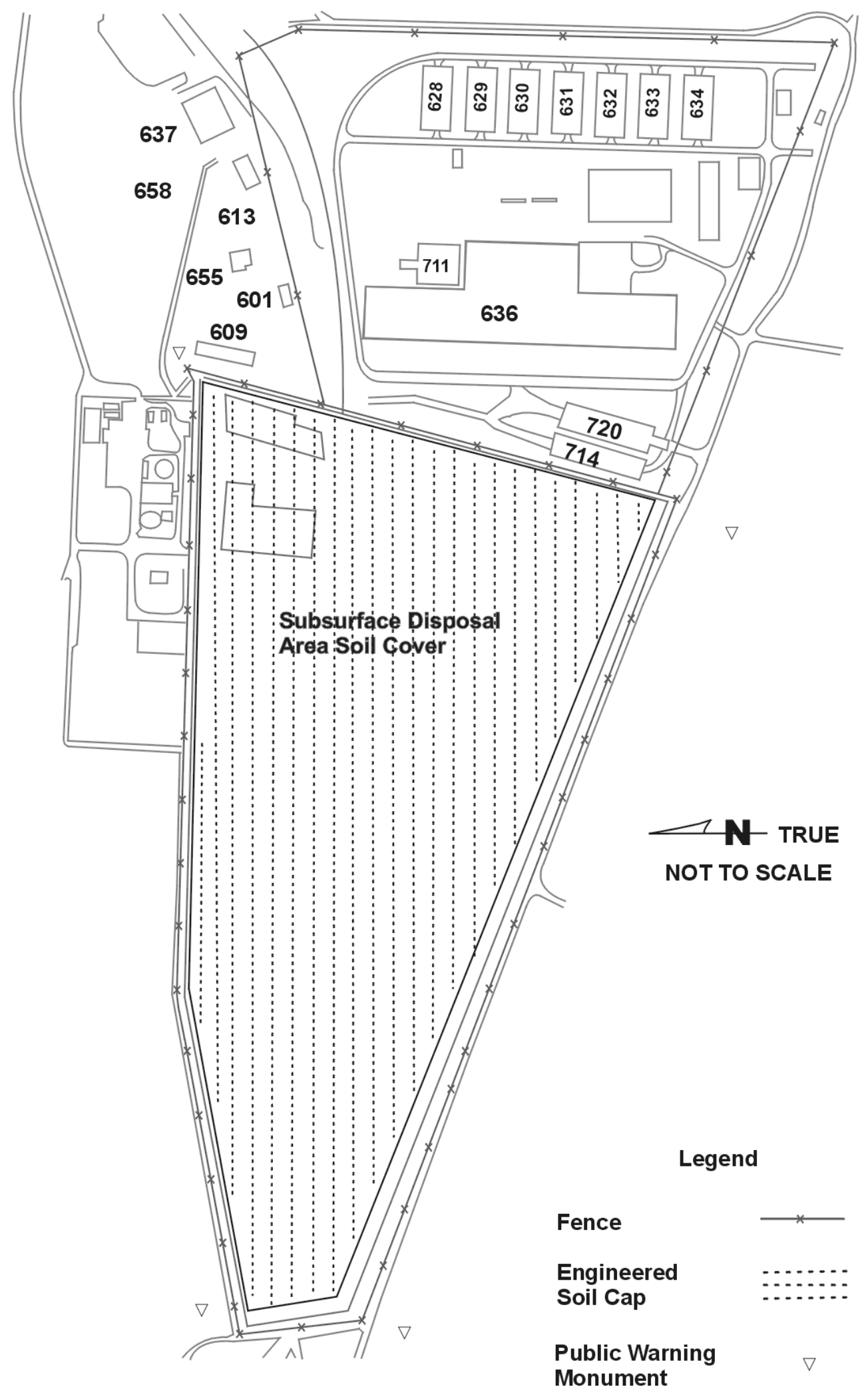

Figure B-3. INEEL Radioactive Waste Management Complex end-state plan map. 


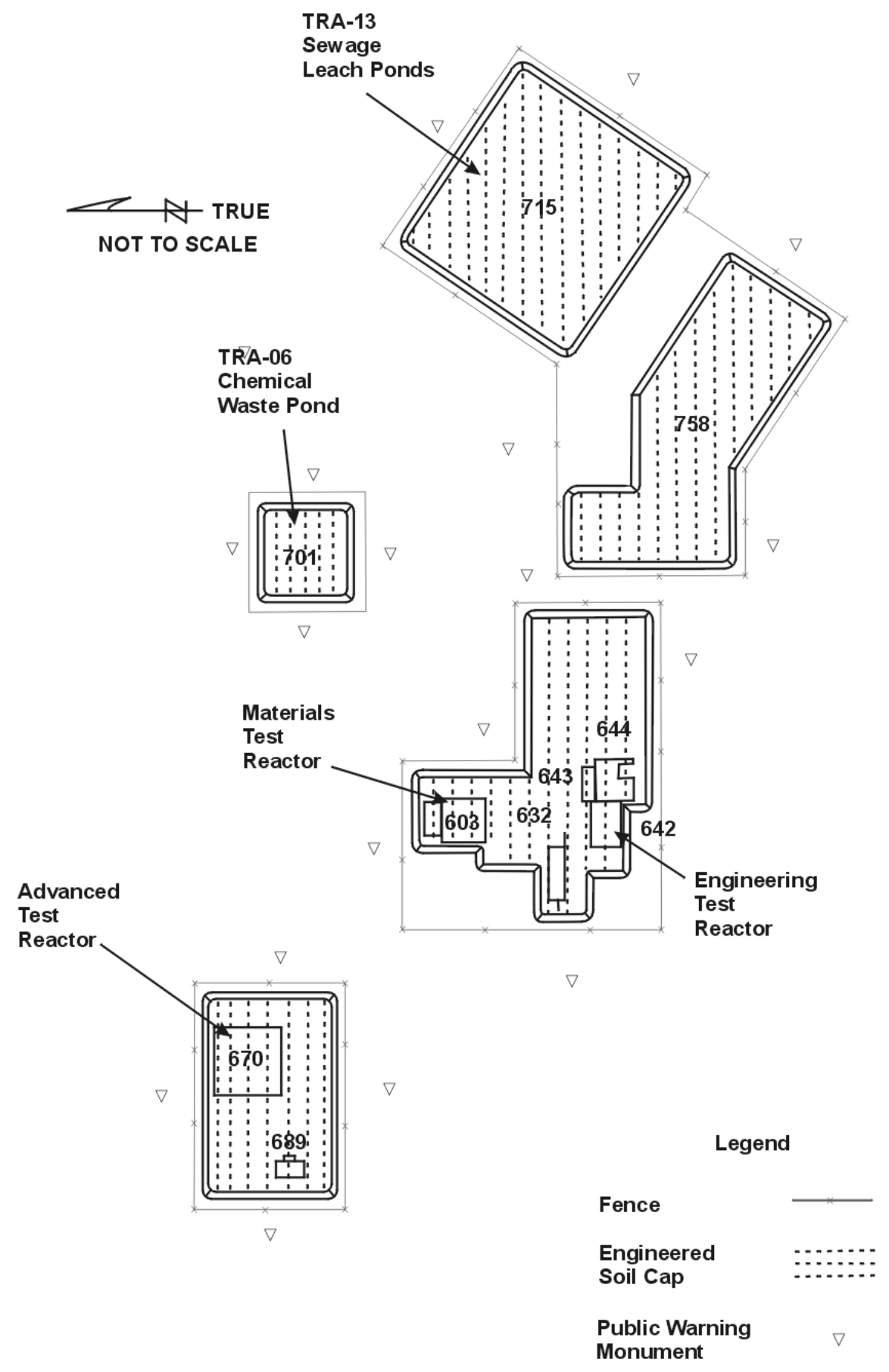

Figure B-4. INEEL Test Reactor Area end-state plan map. 


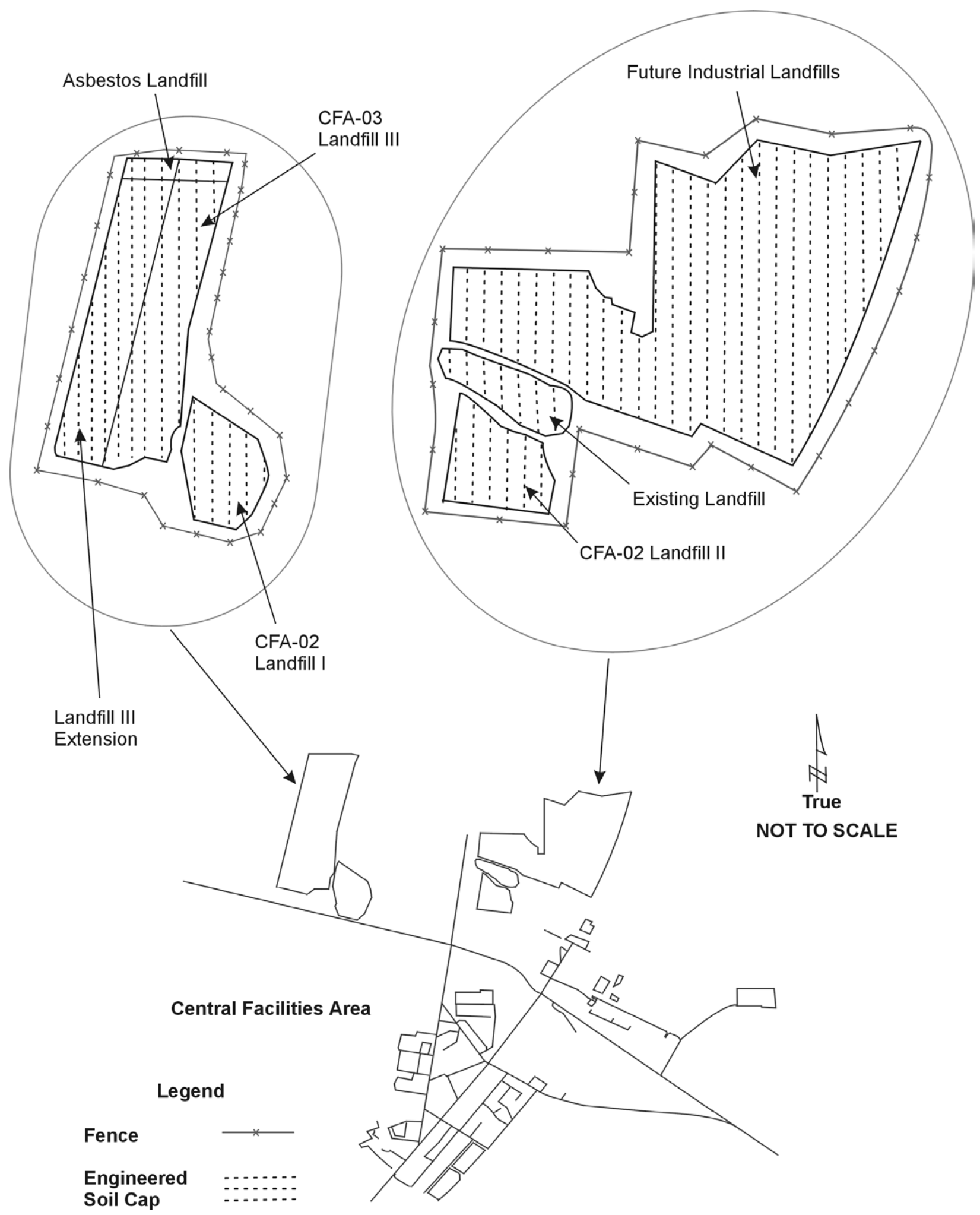

Figure B-5. INEEL Central Facilities Area end-state plan map. 
Legend

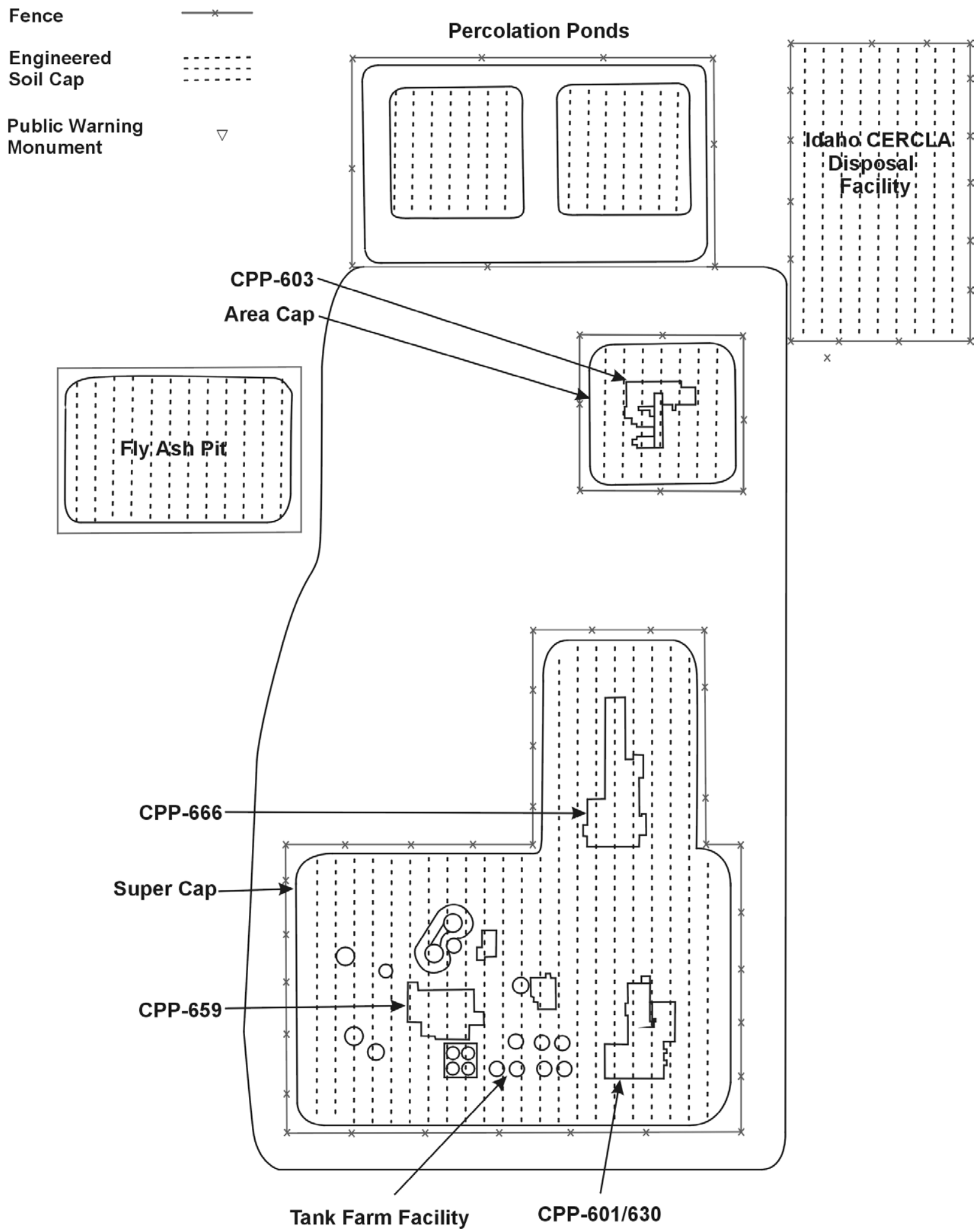

Figure B-6. INEEL Idaho Nuclear Technology and Engineering Center end-state plan map. 


\section{Appendix C}

Idaho National Engineering and Environmental Laboratory Schedule for Sites to enter Long-Term Stewardship 
C-2 


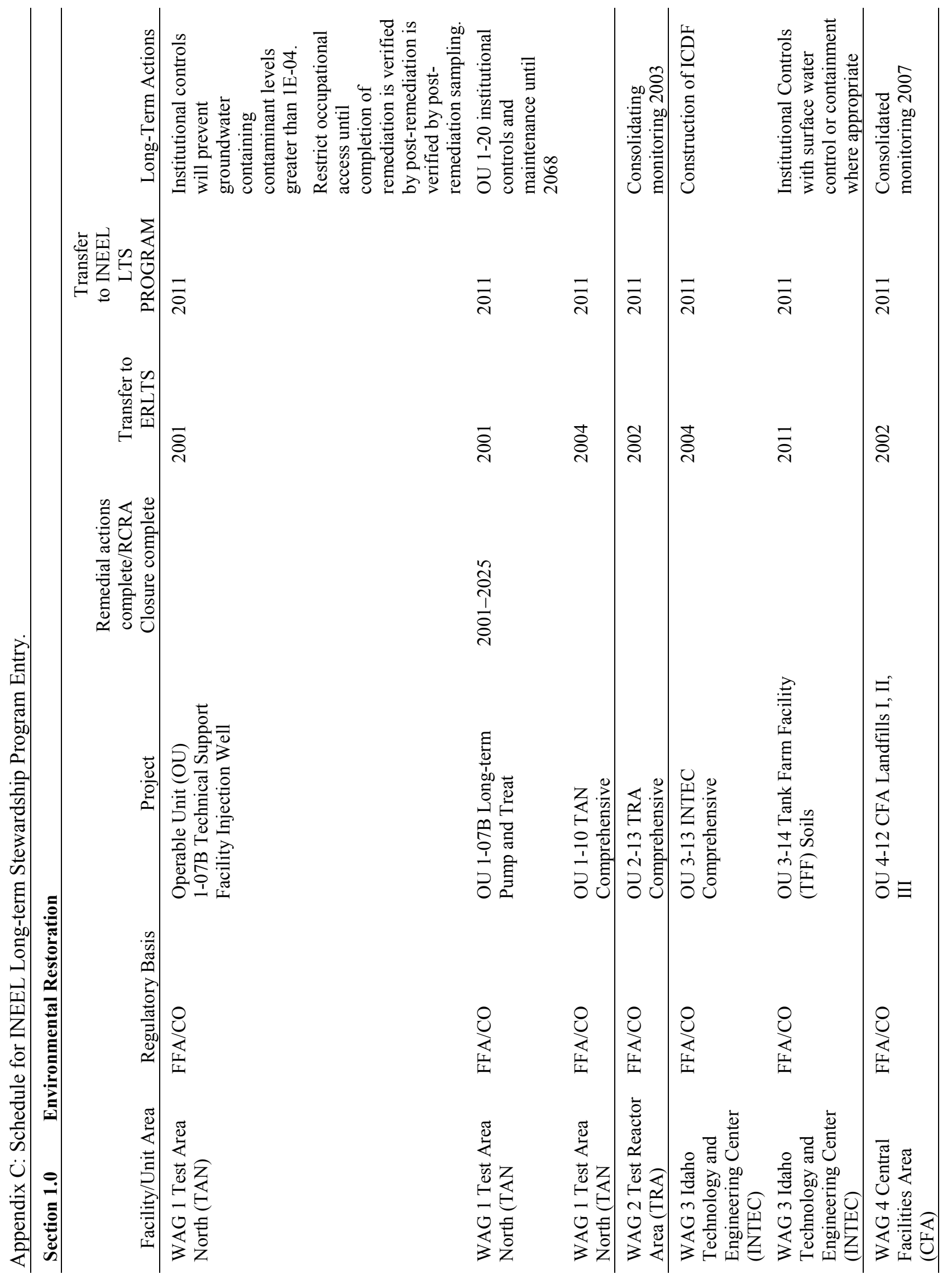

C-3 


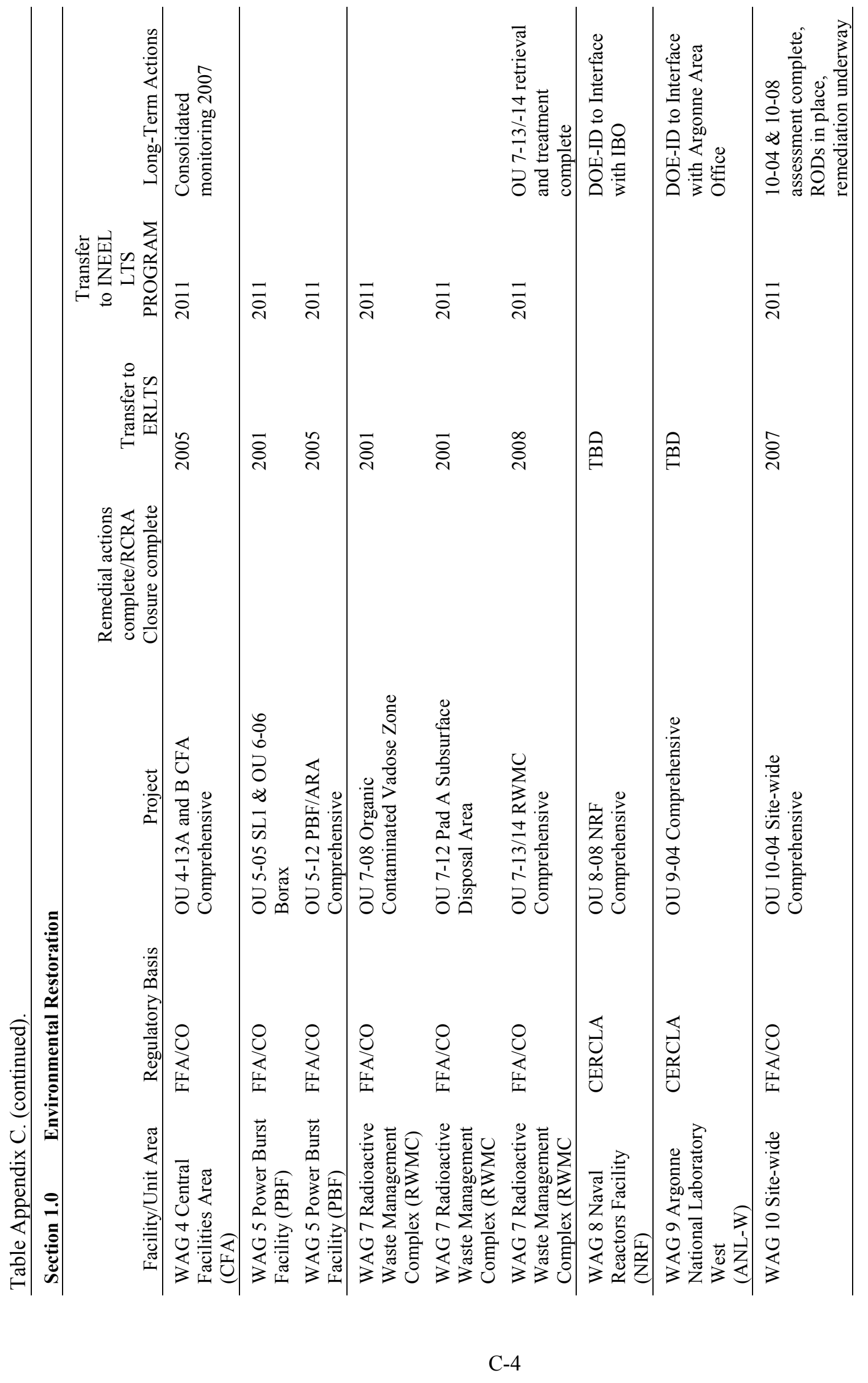




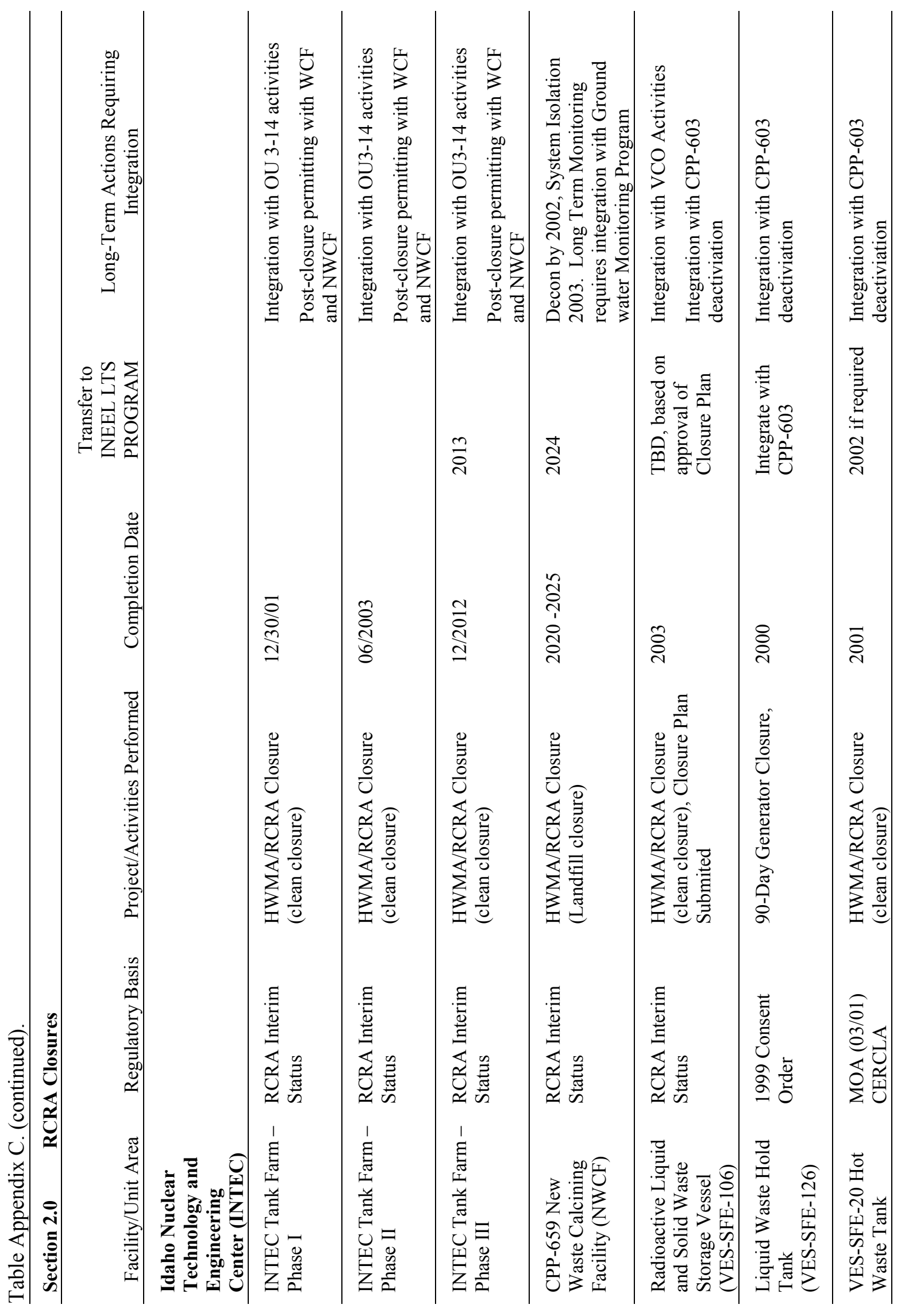




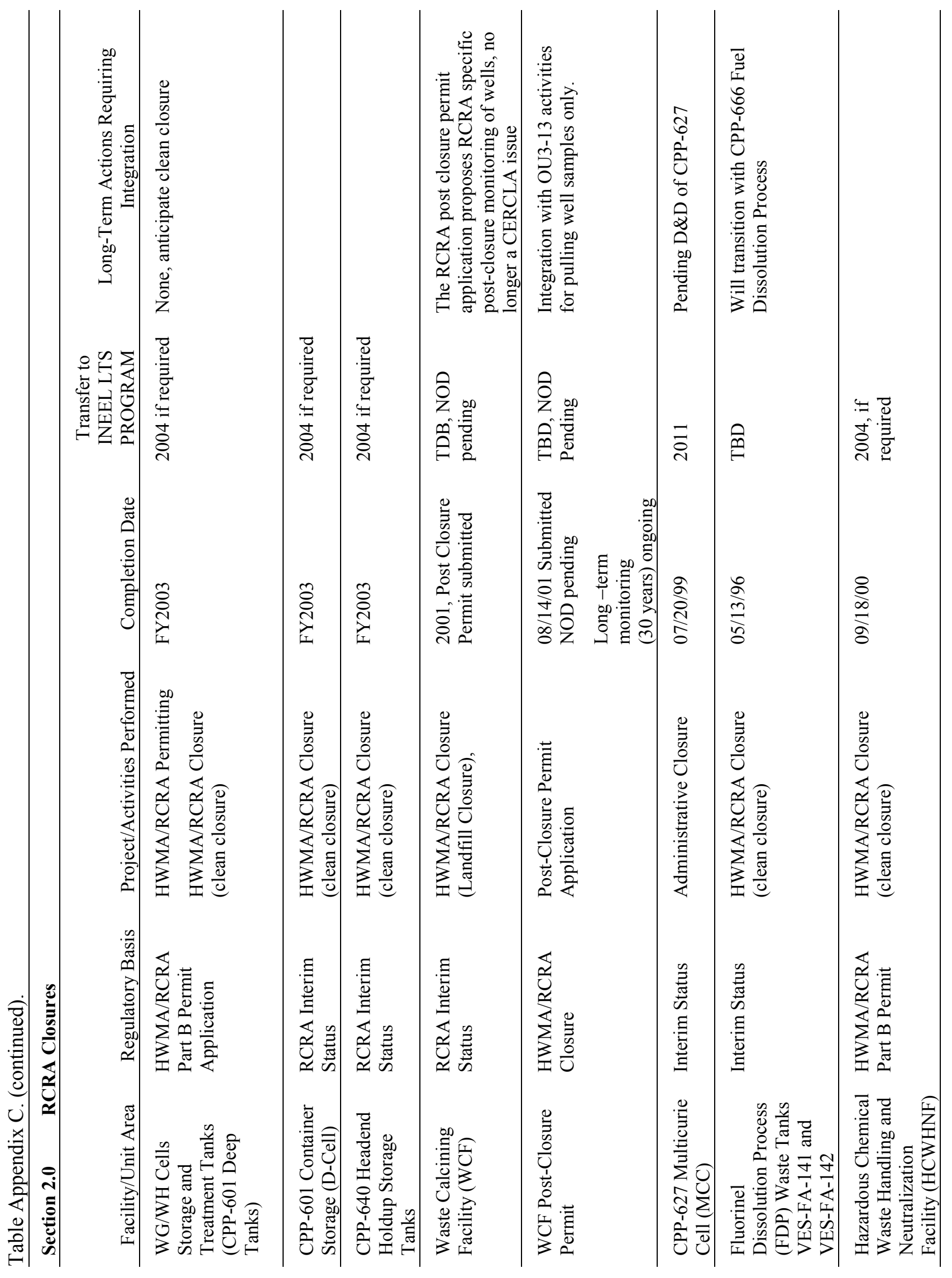




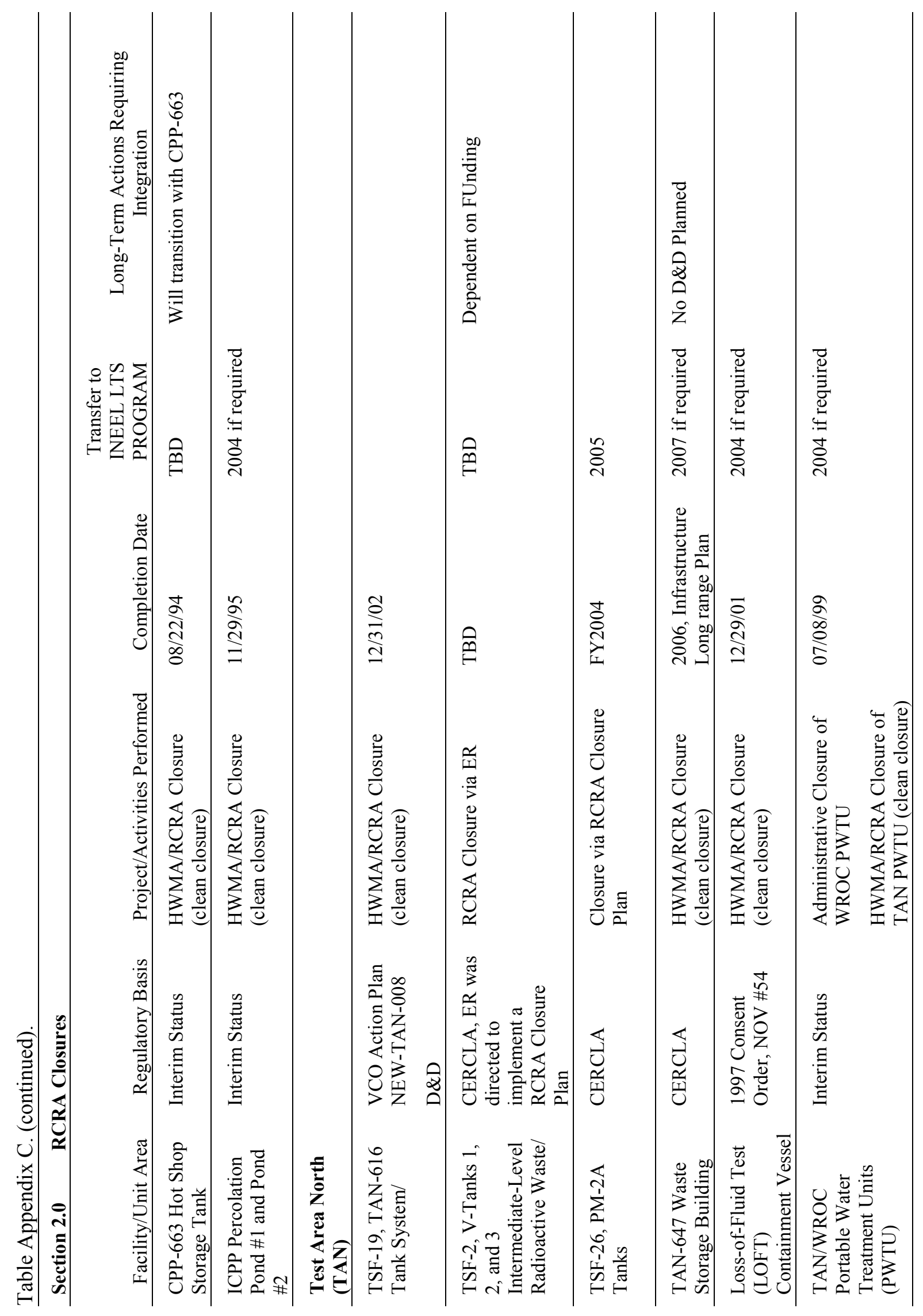




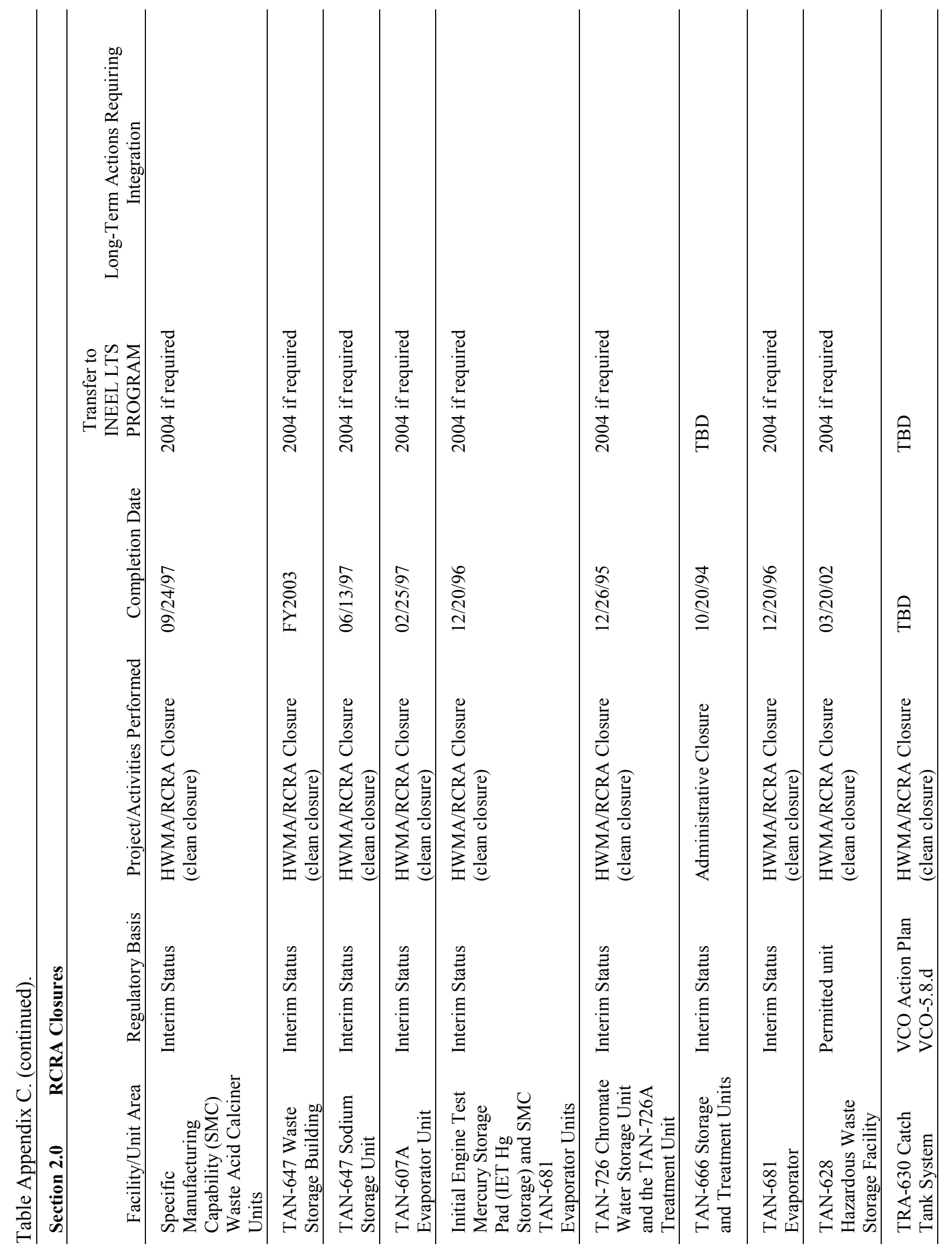




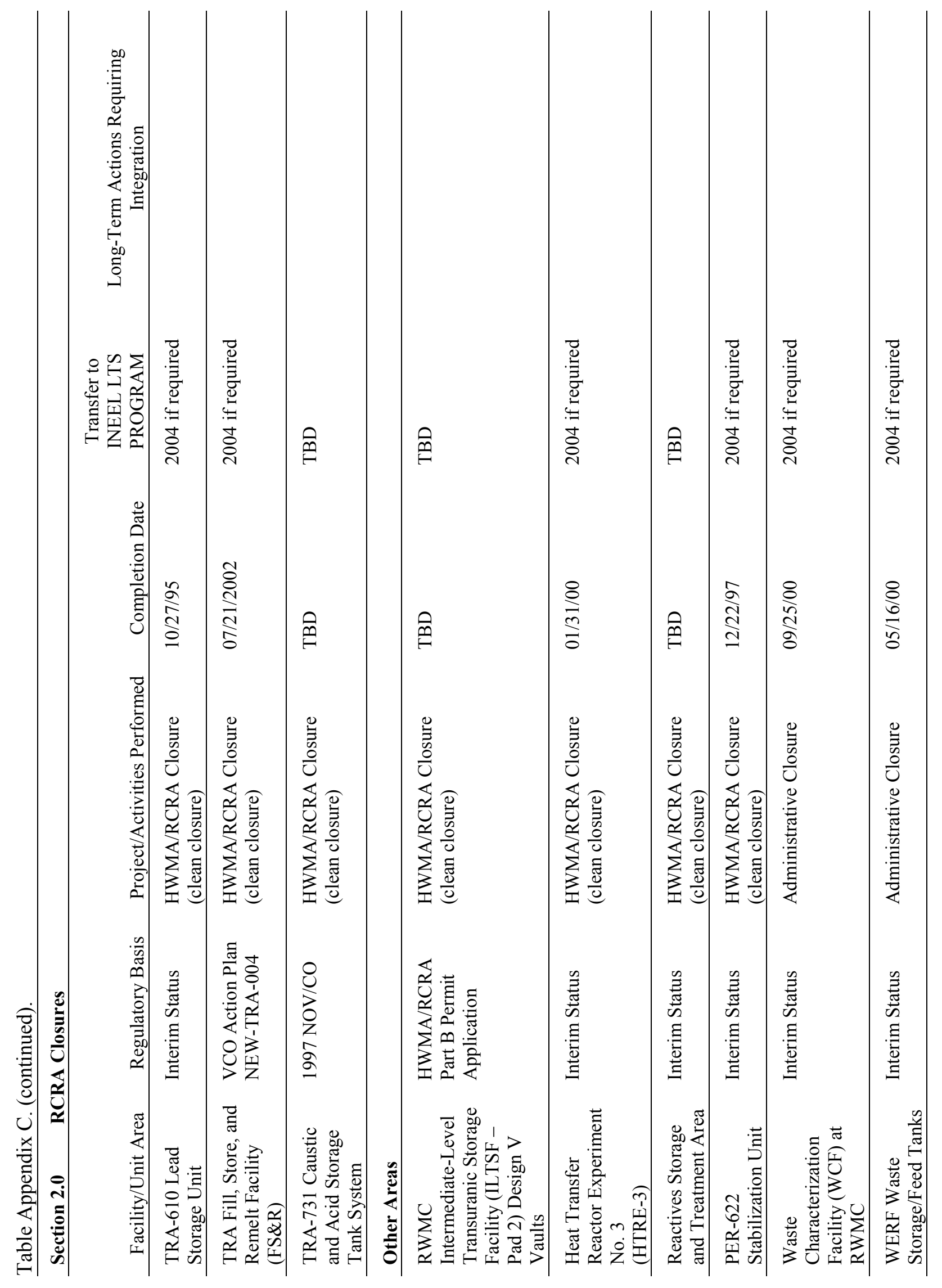




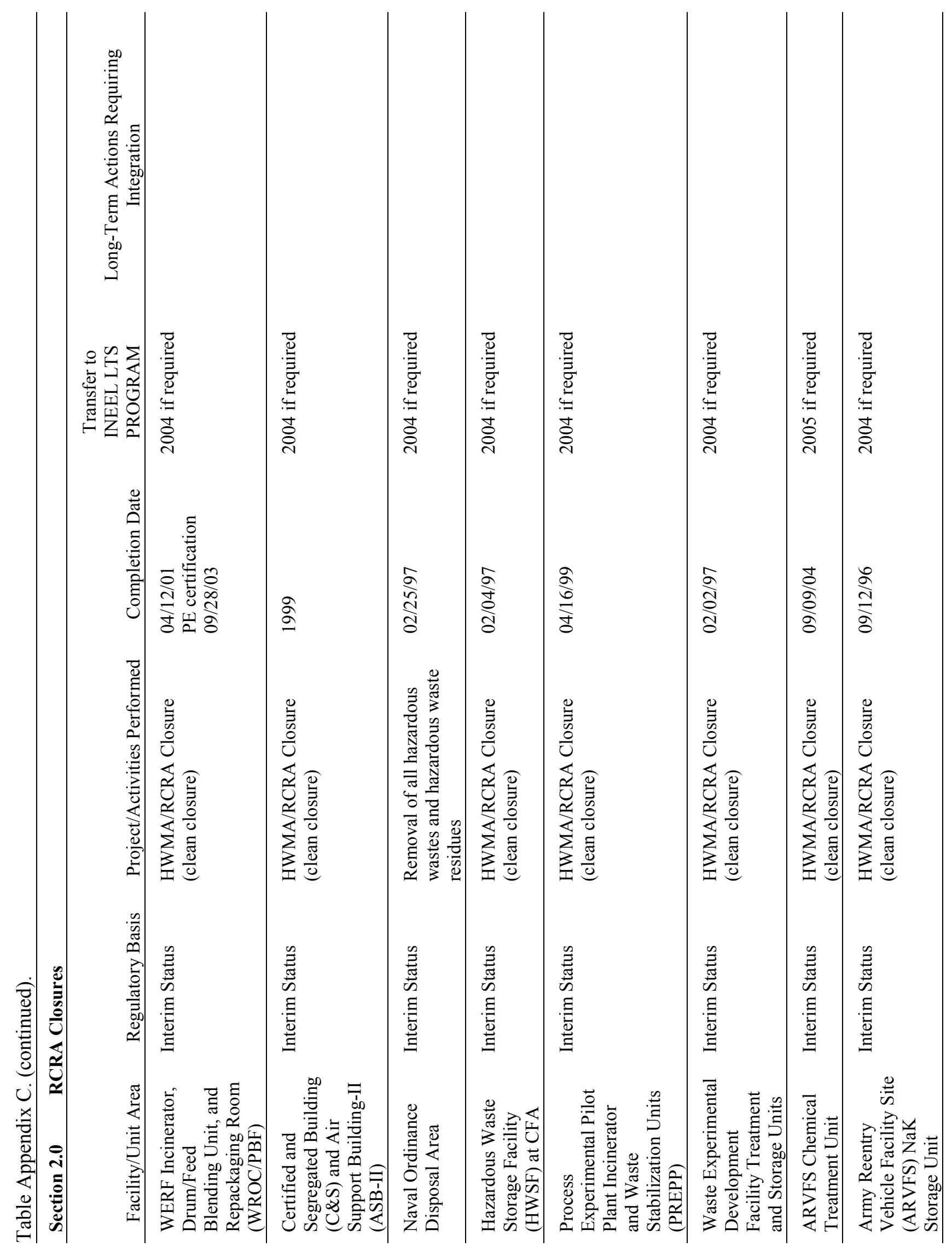




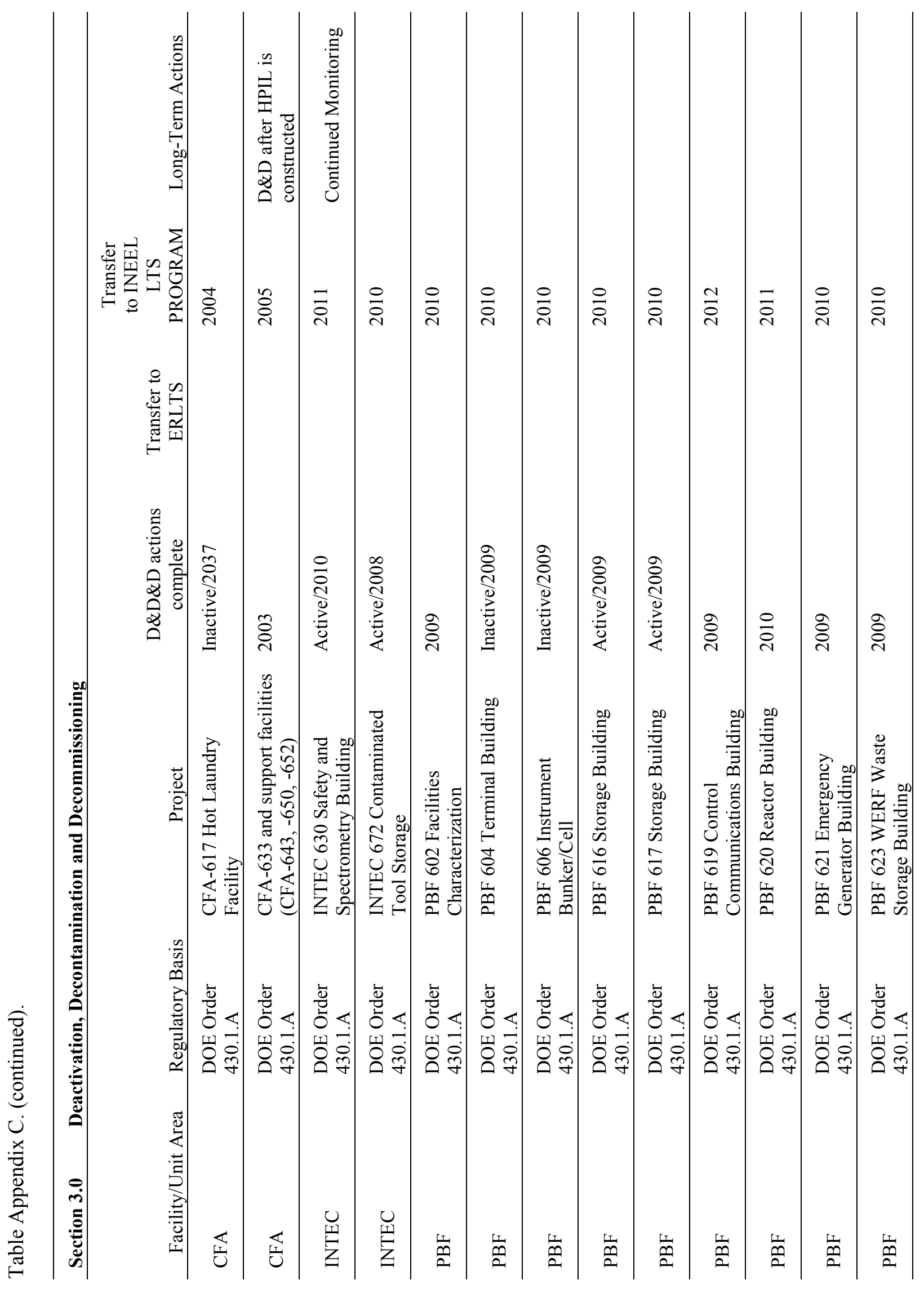




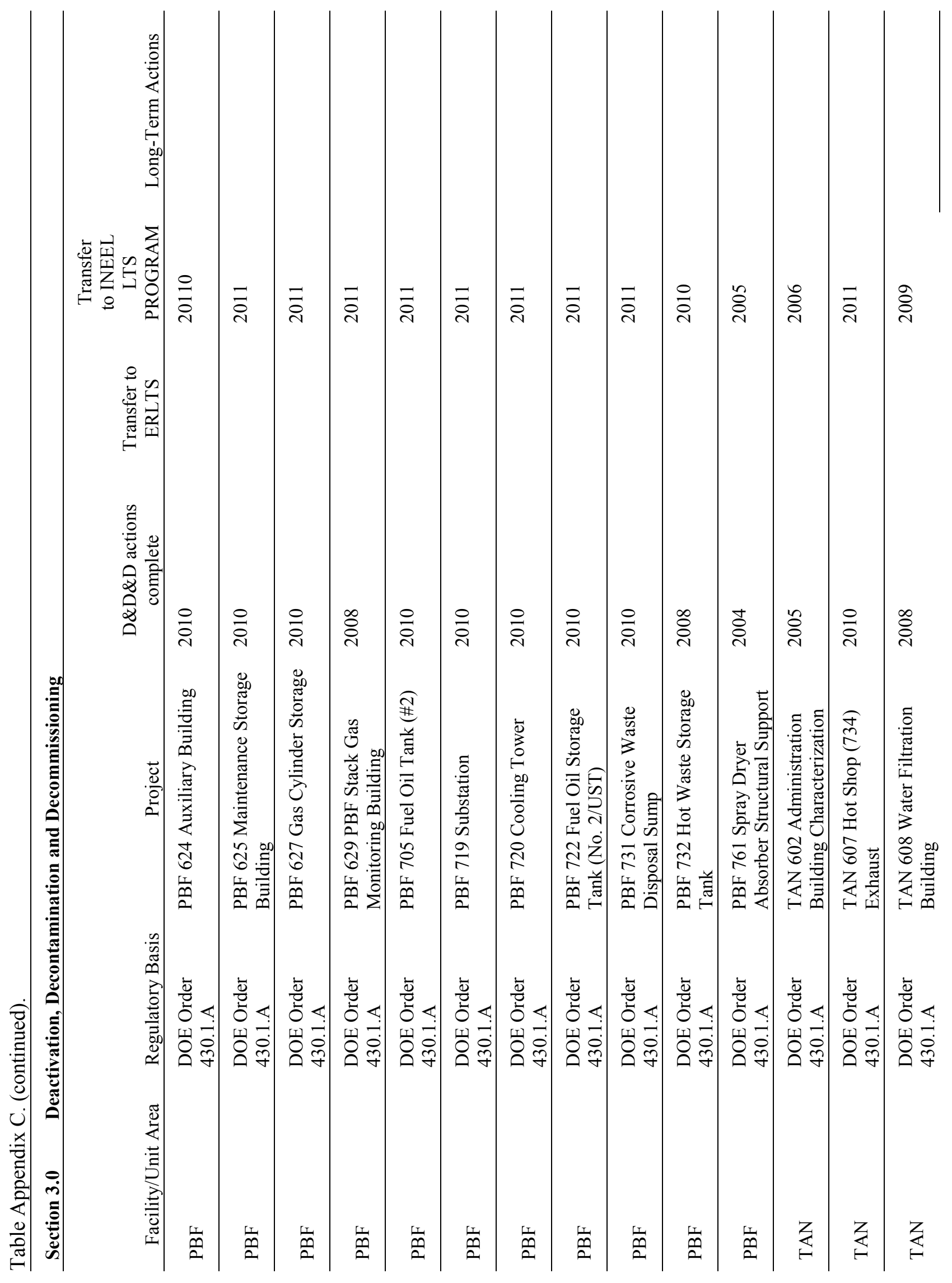




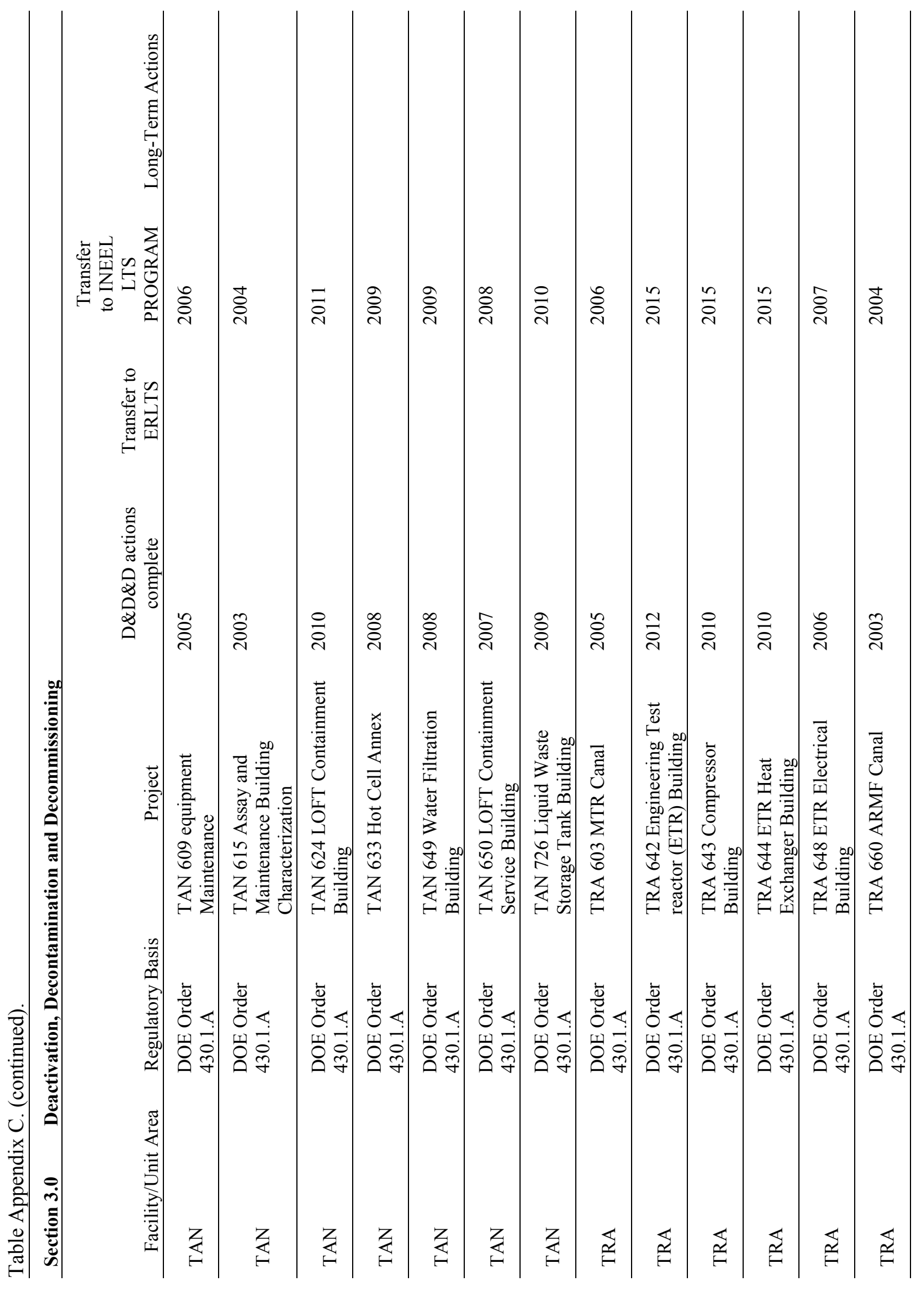




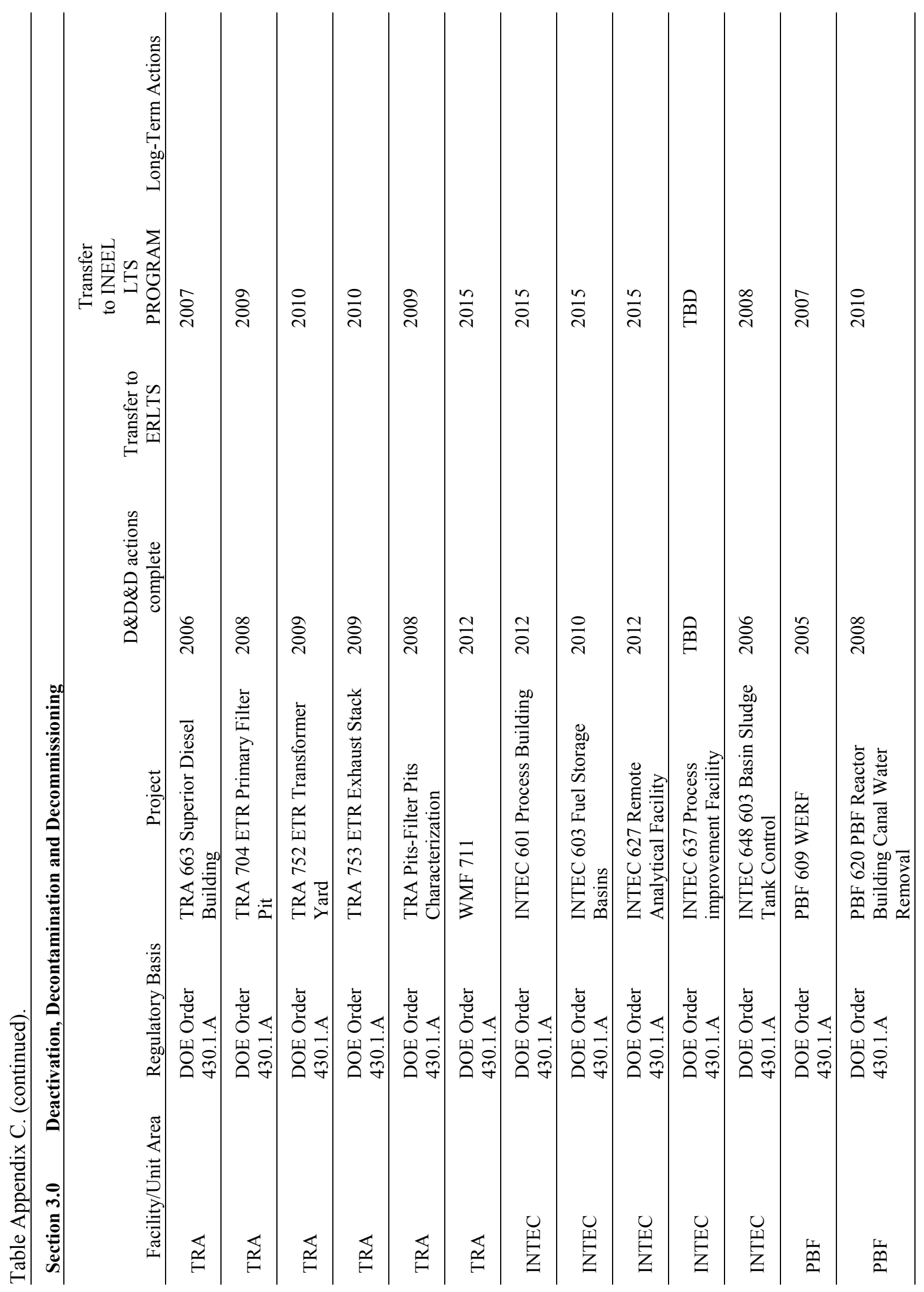




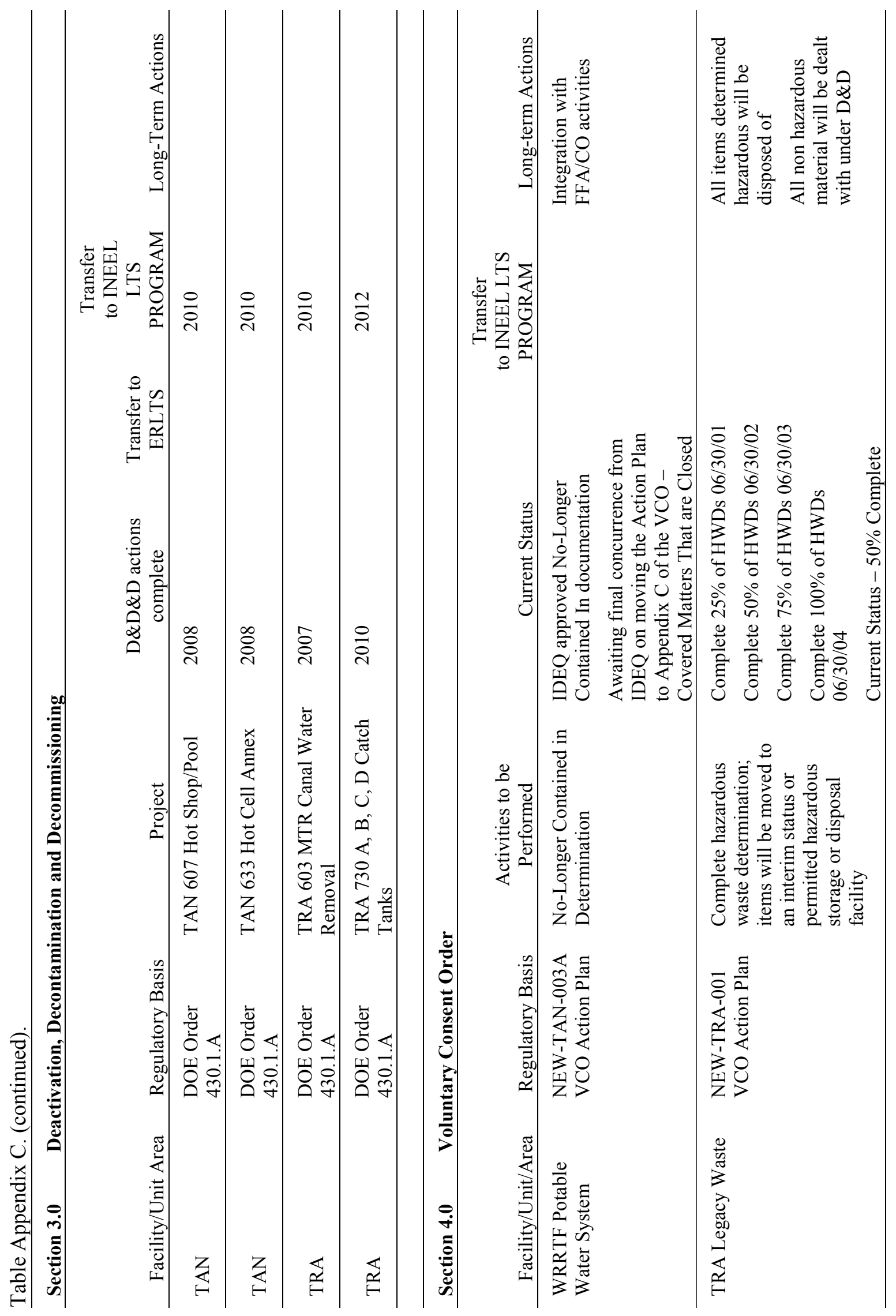




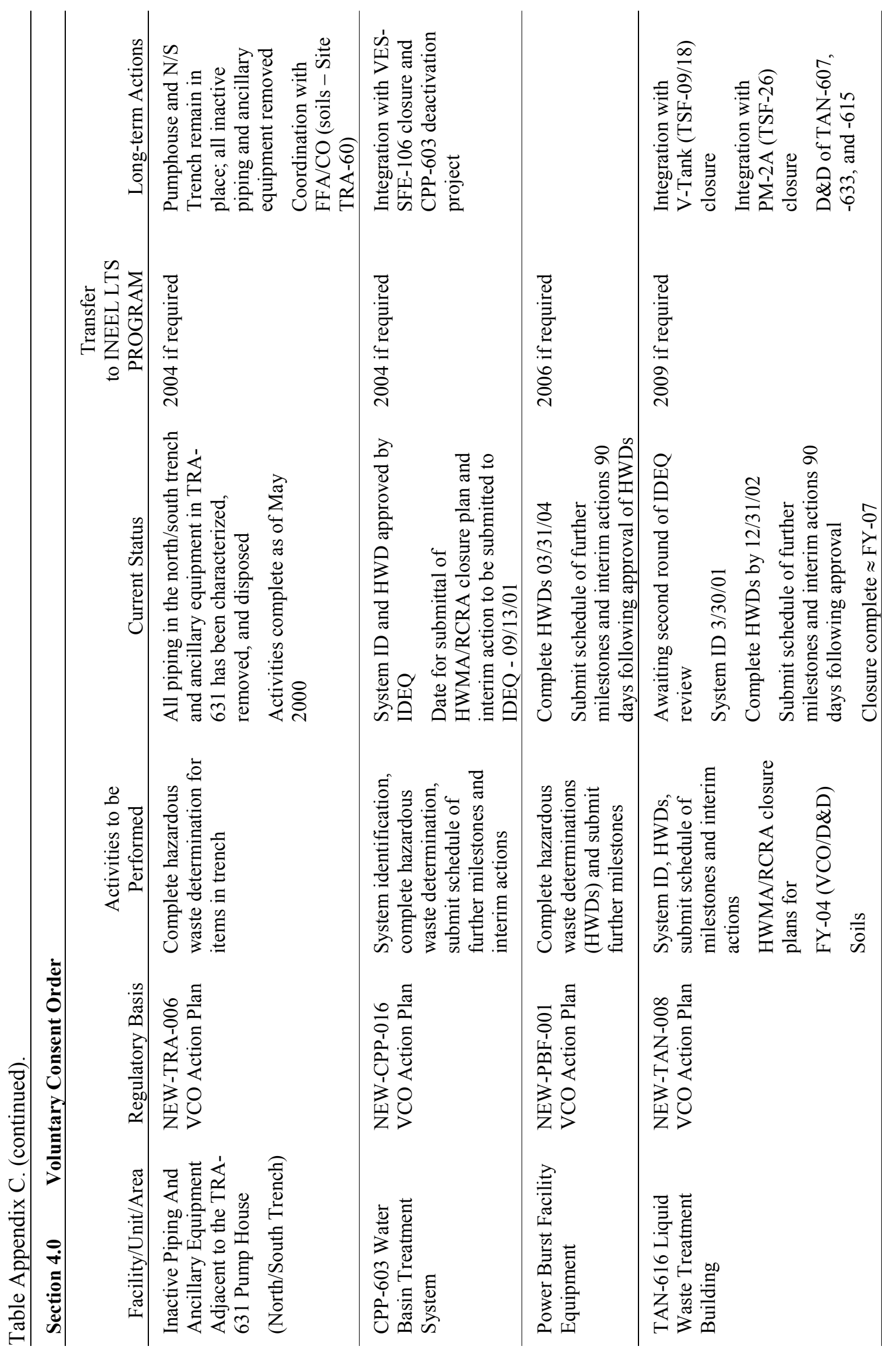




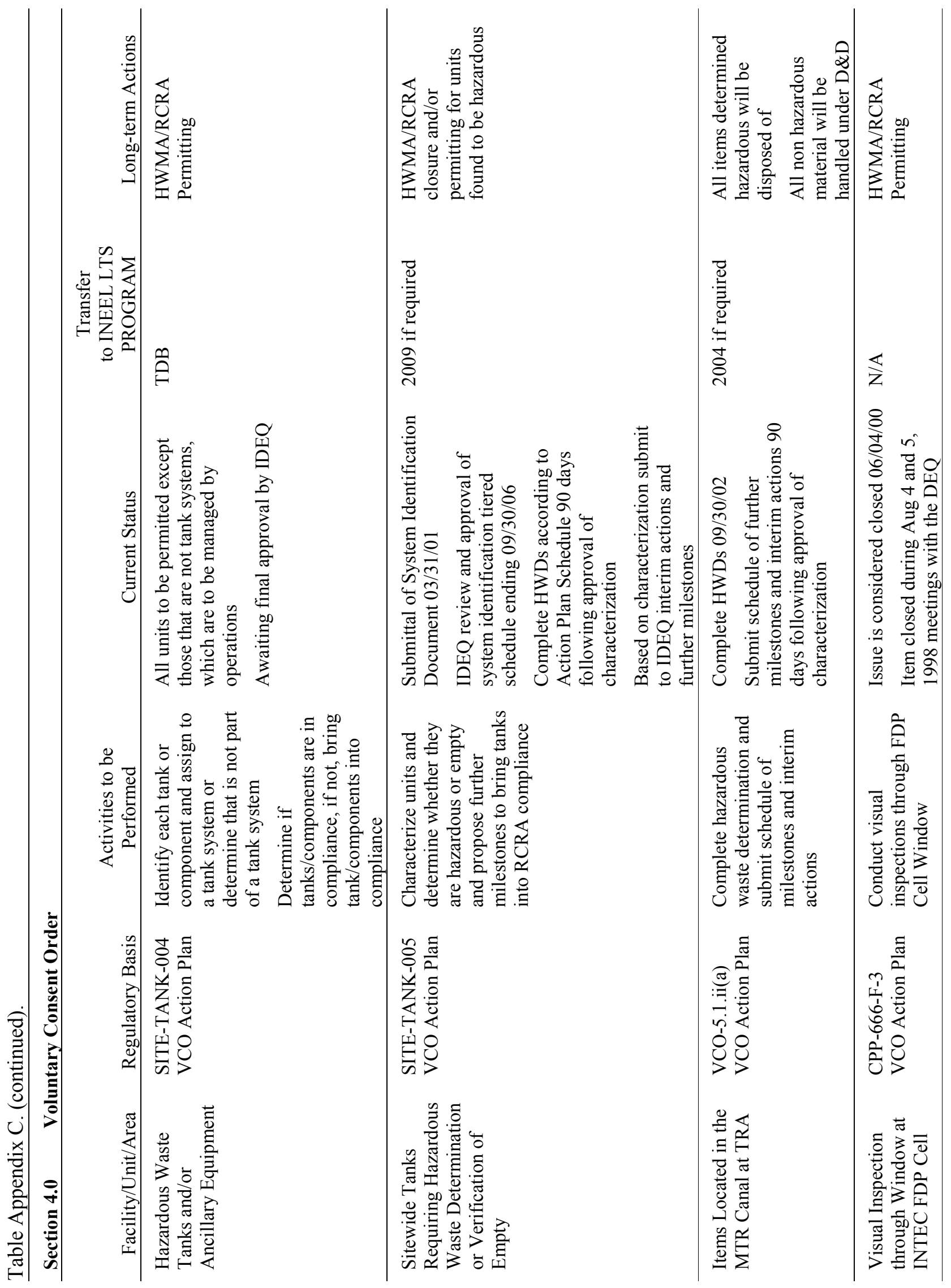




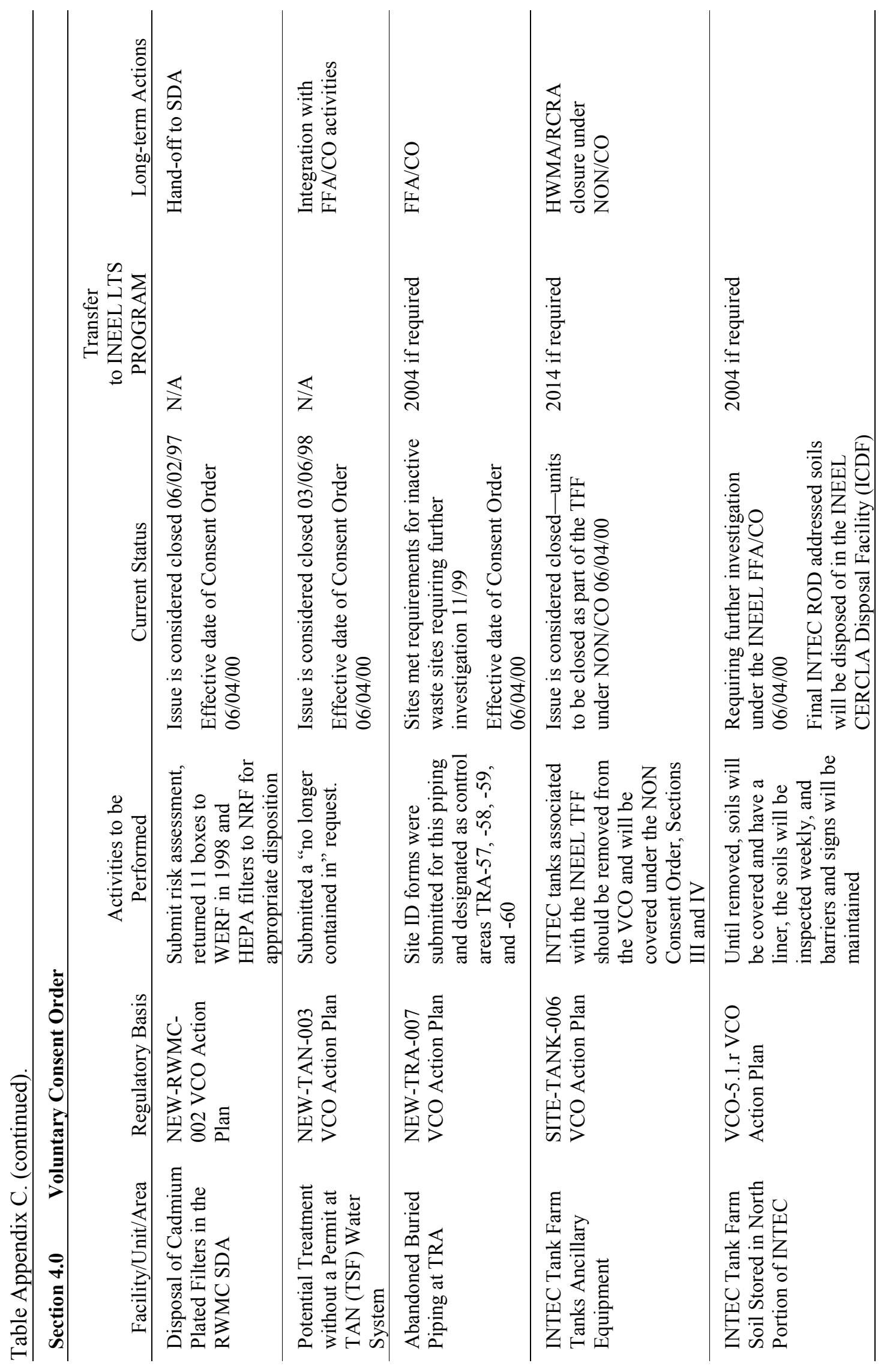




\section{Appendix D}

Historic INEEL Architectural Properties List, Assessment of Eligibility and Mitigation 
D-2 

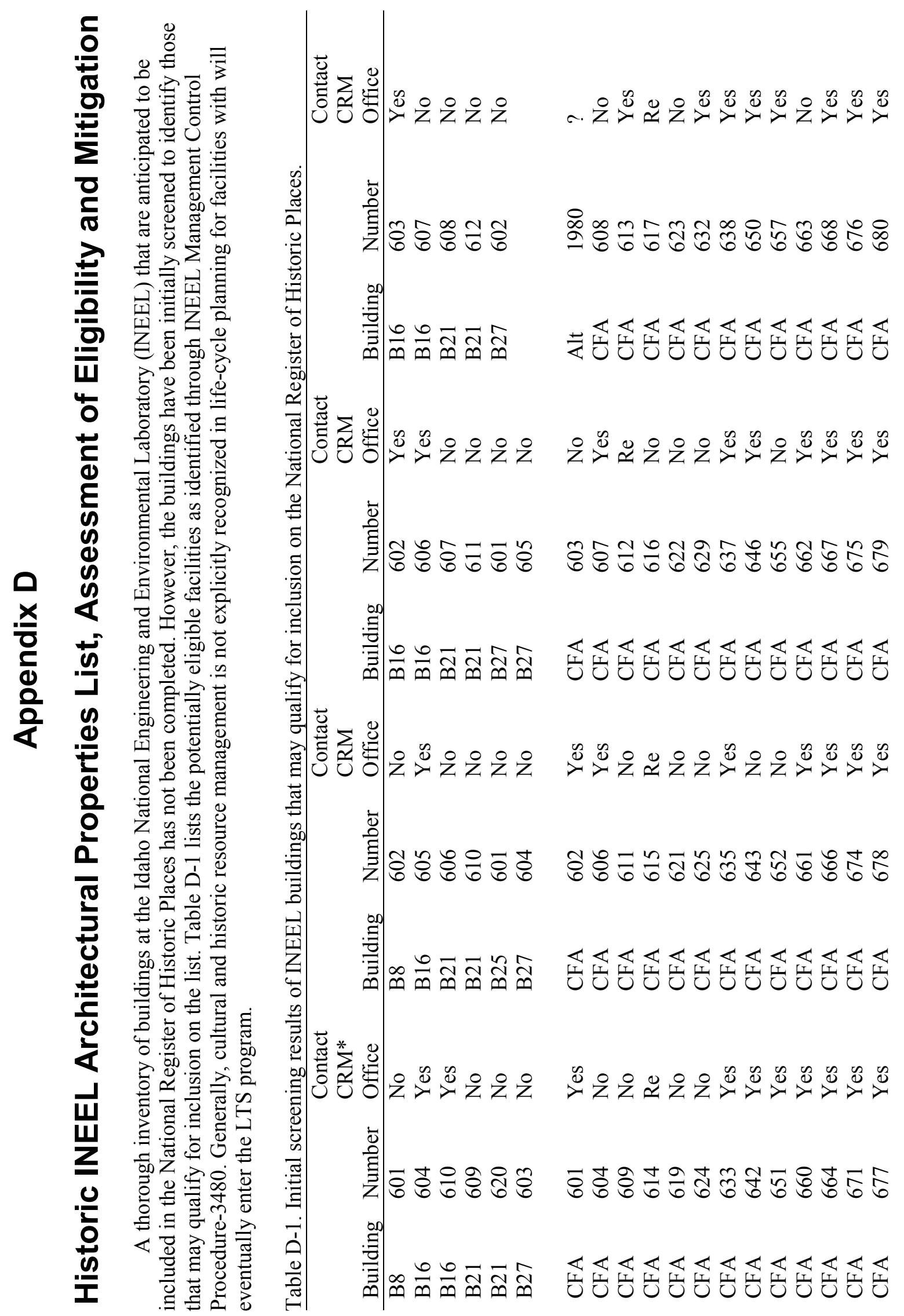

D-3 


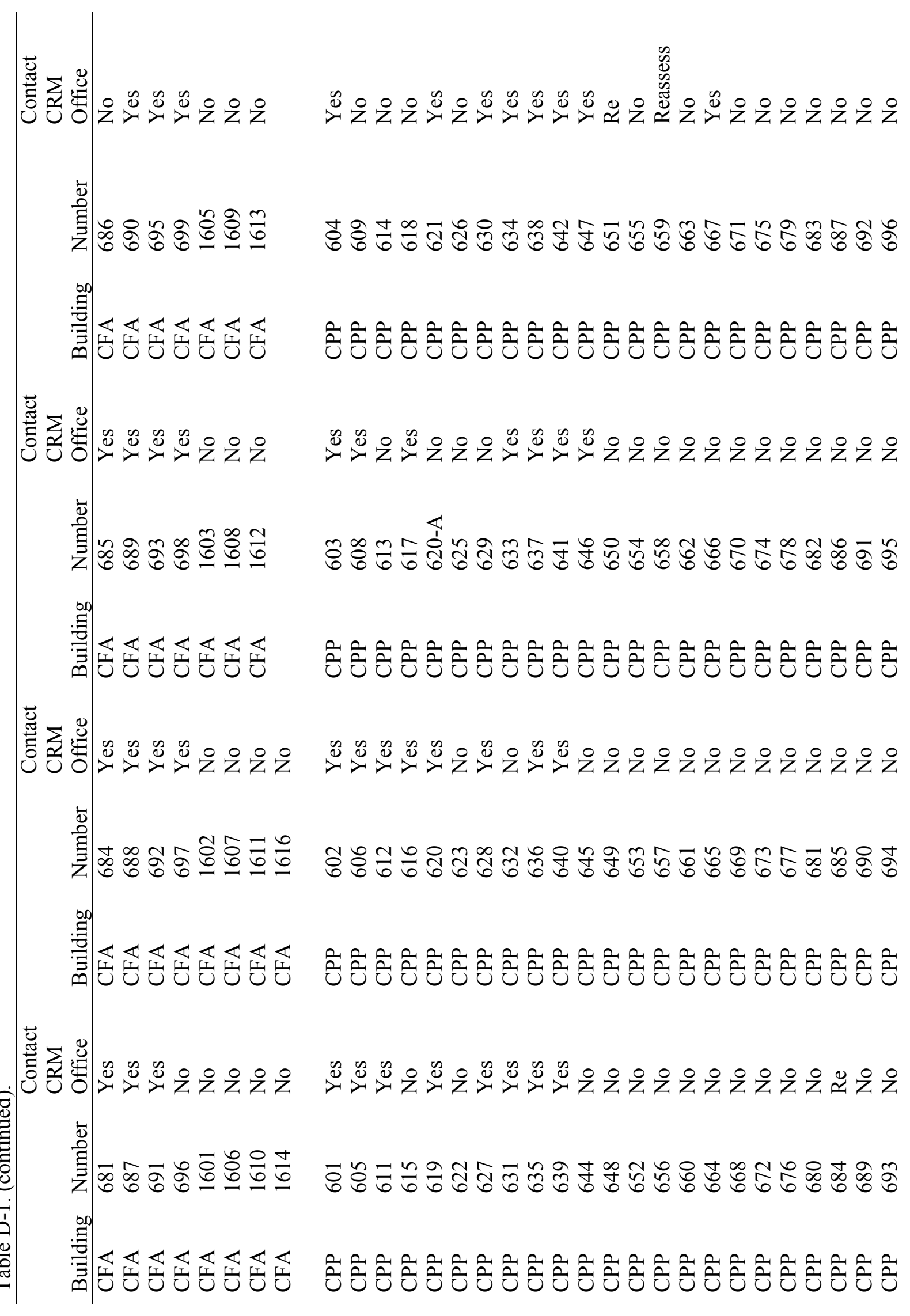

D-4 


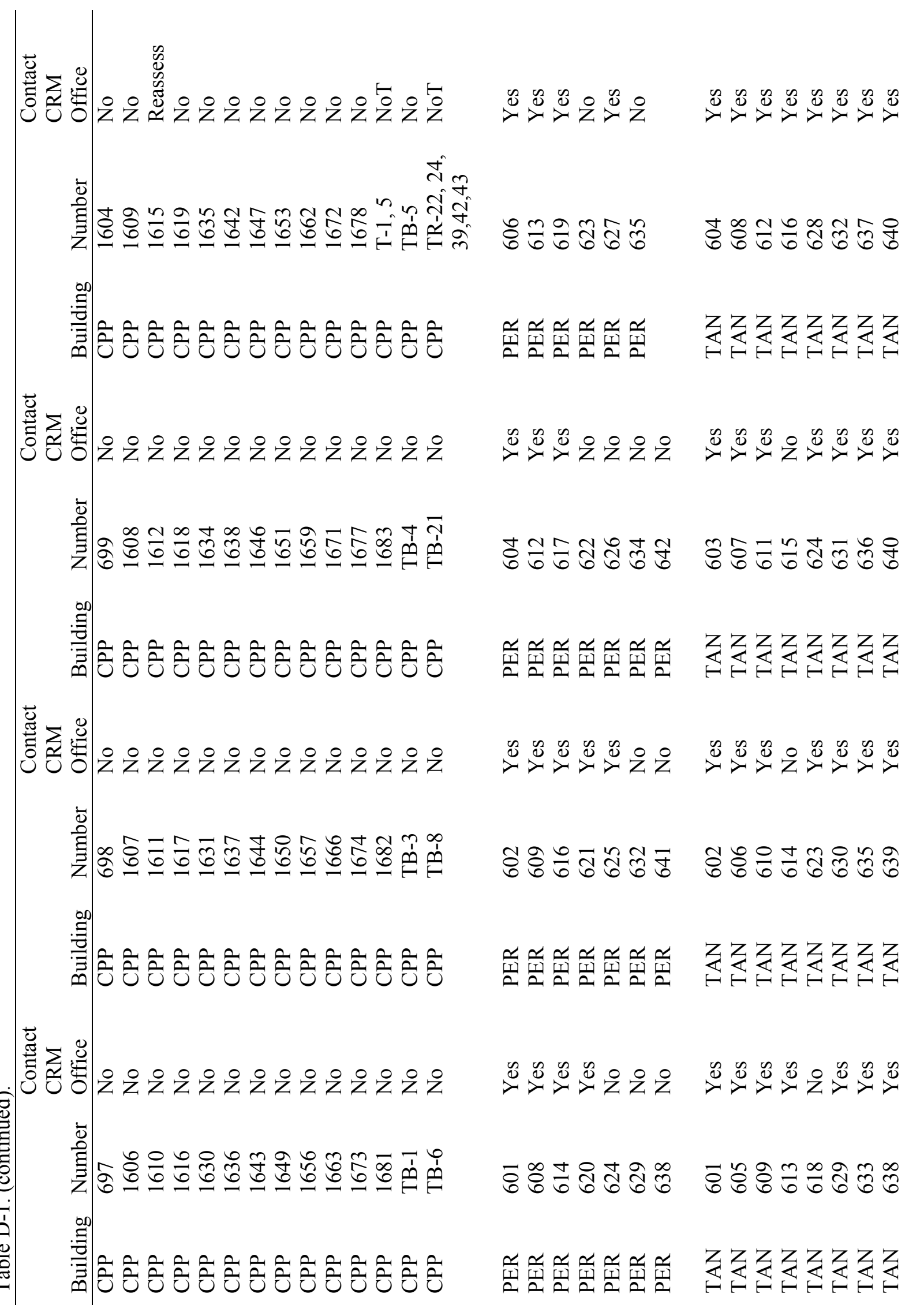




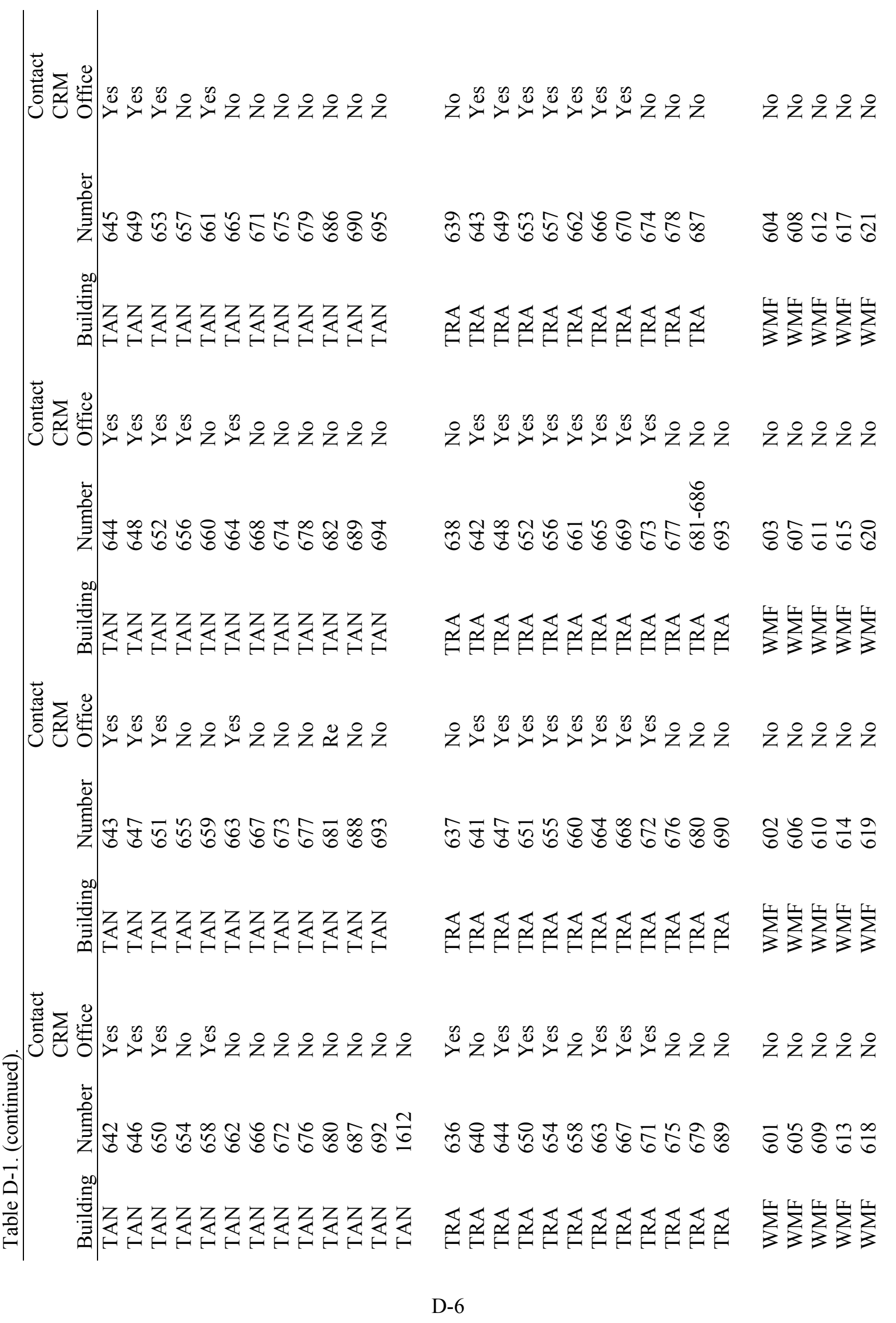




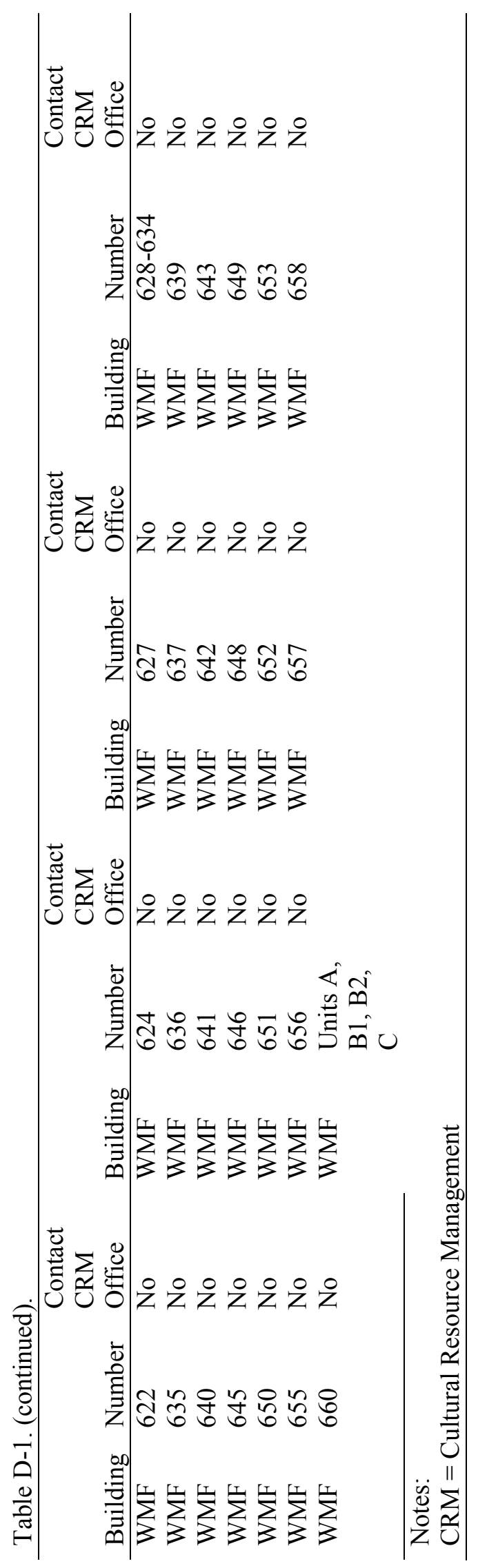

D-7 
D-8 


\section{Appendix E \\ End-State Plan Critical Path Events, Assumptions, and Issues}


E-2 


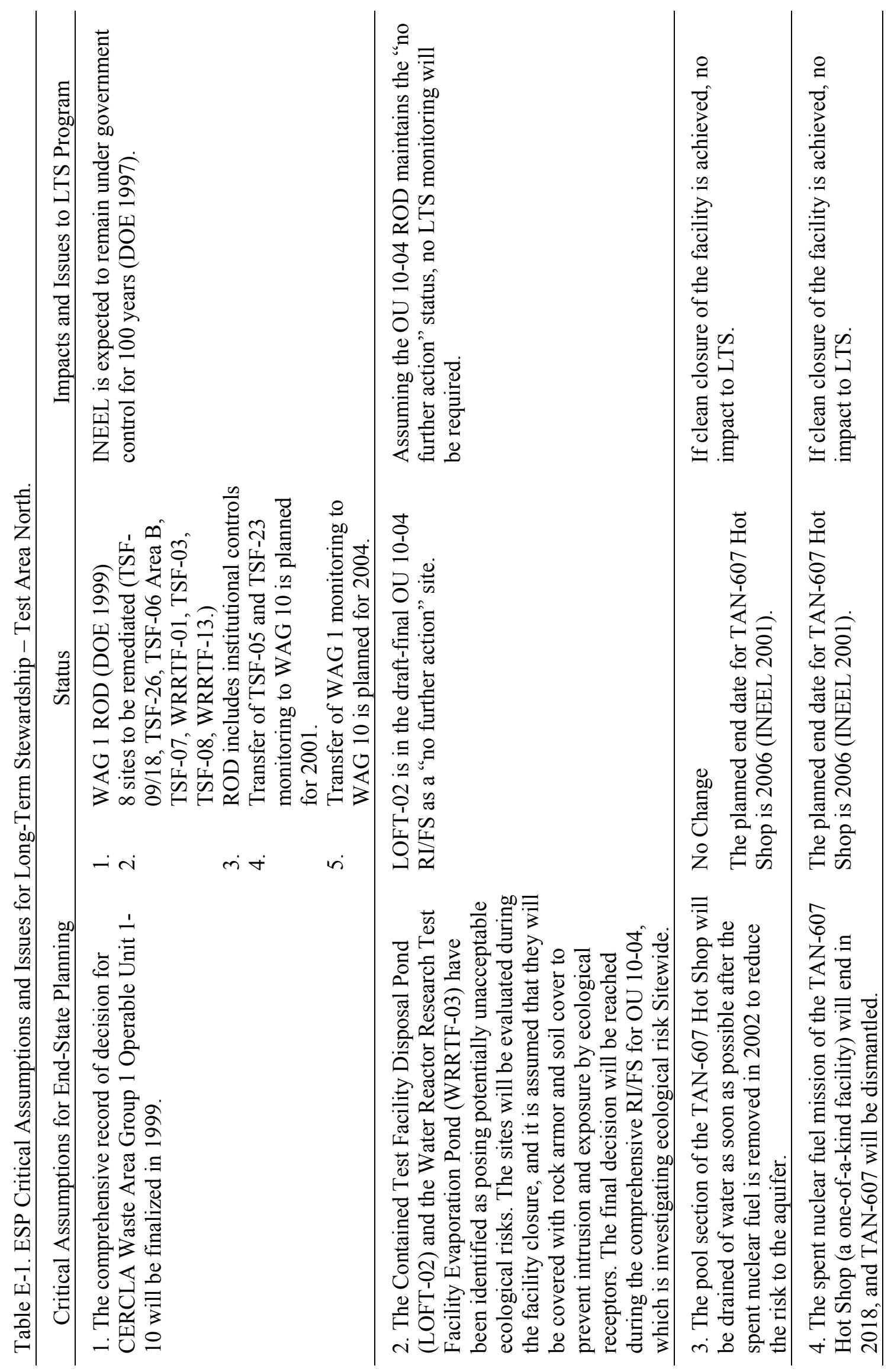




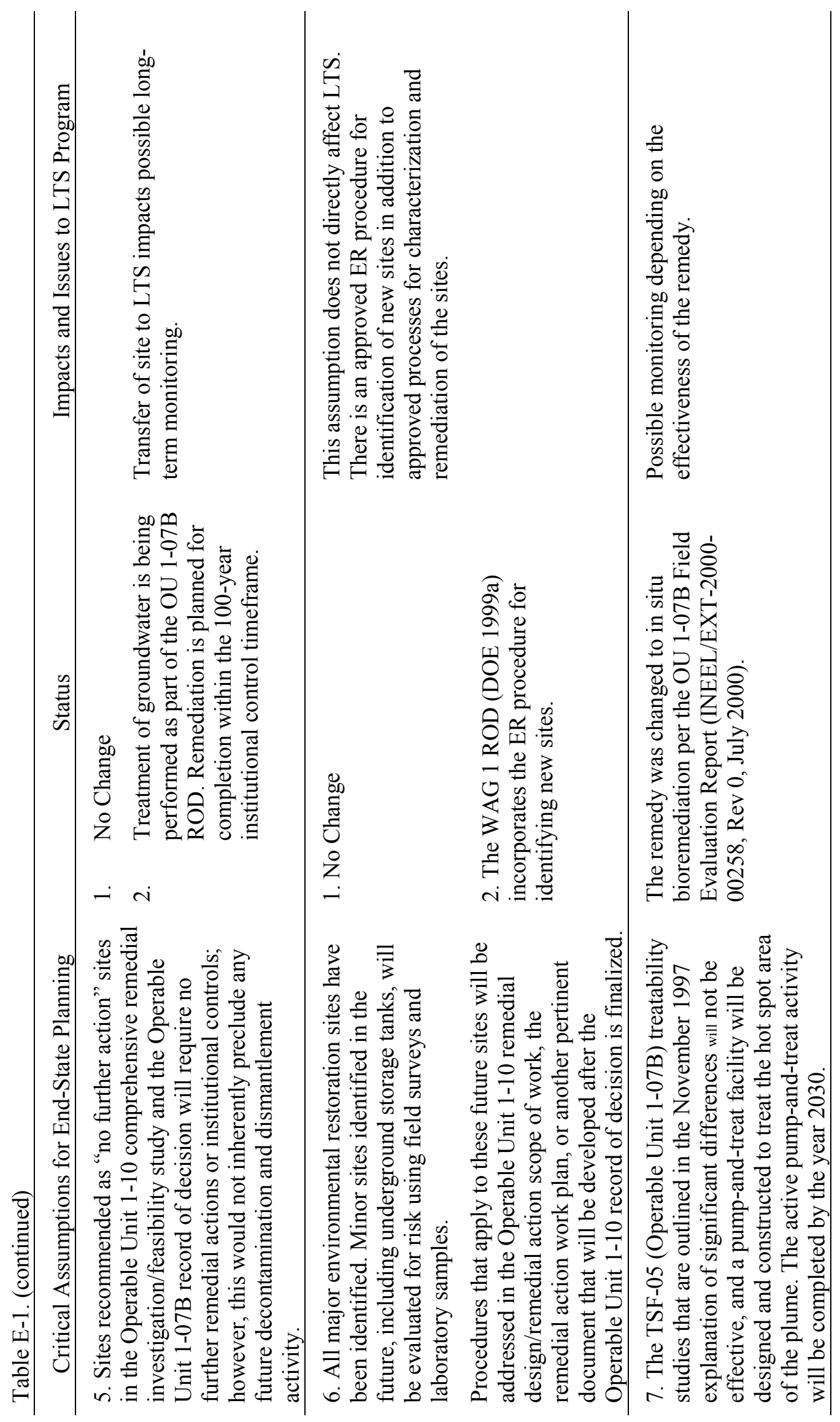




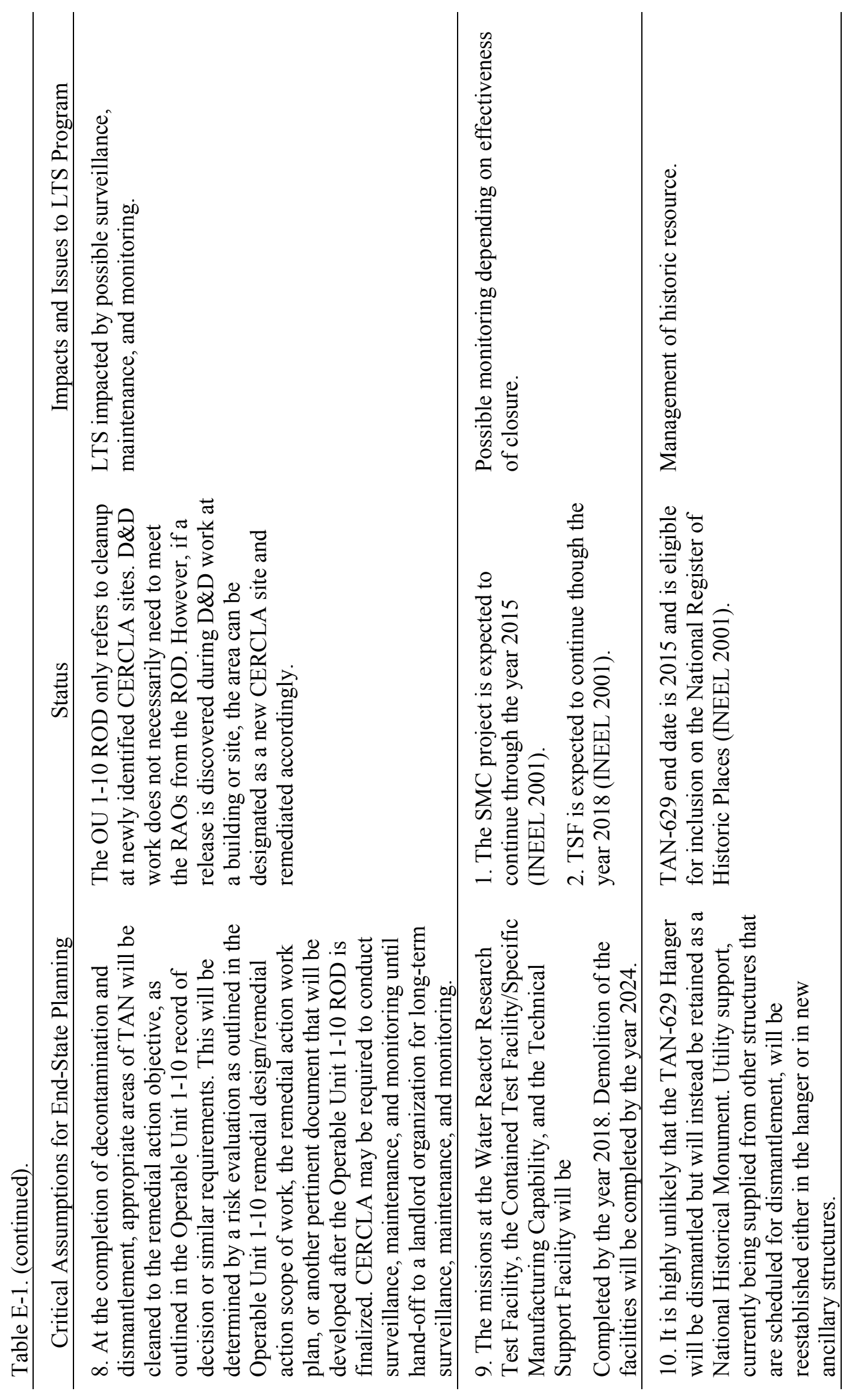




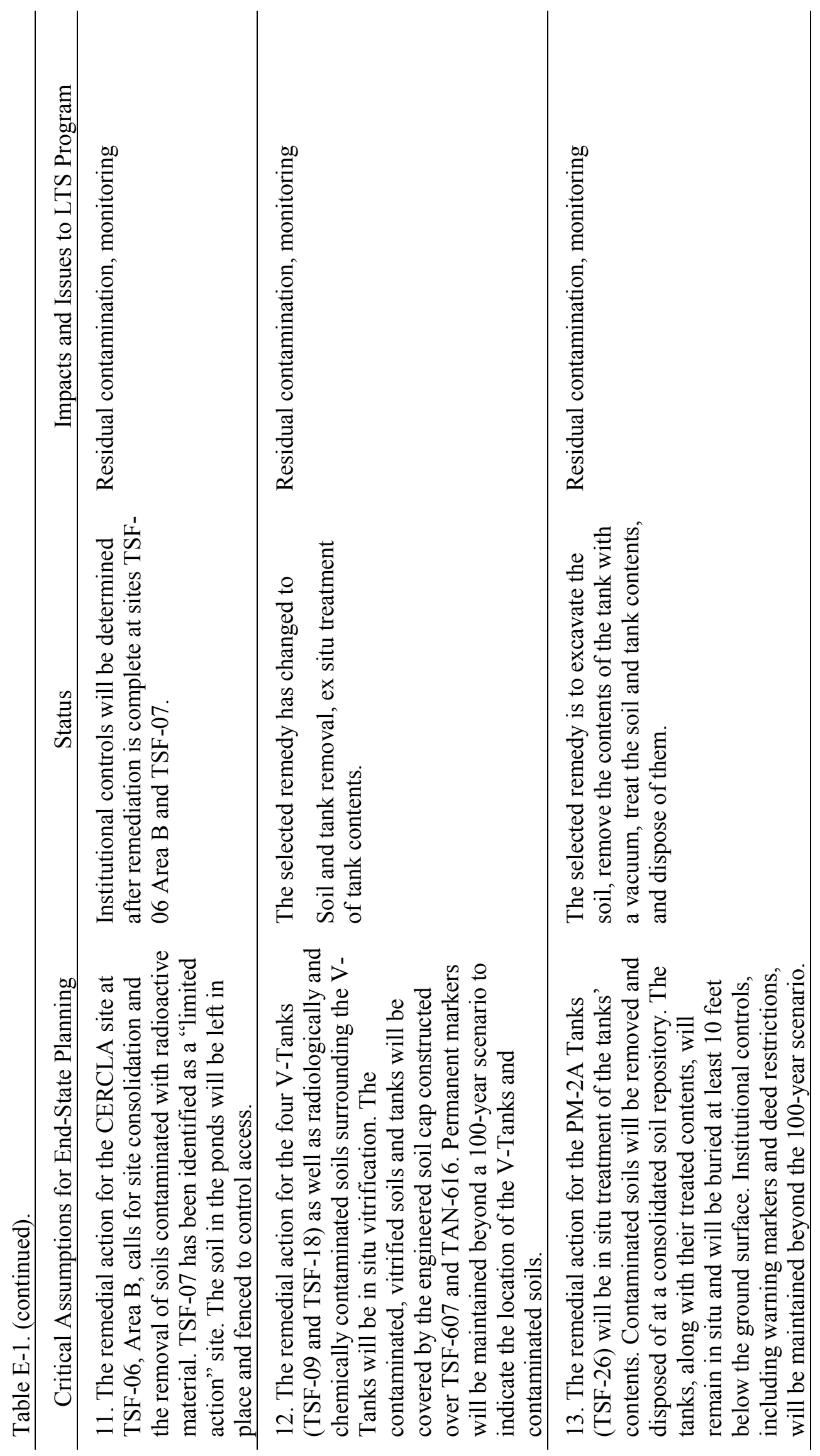




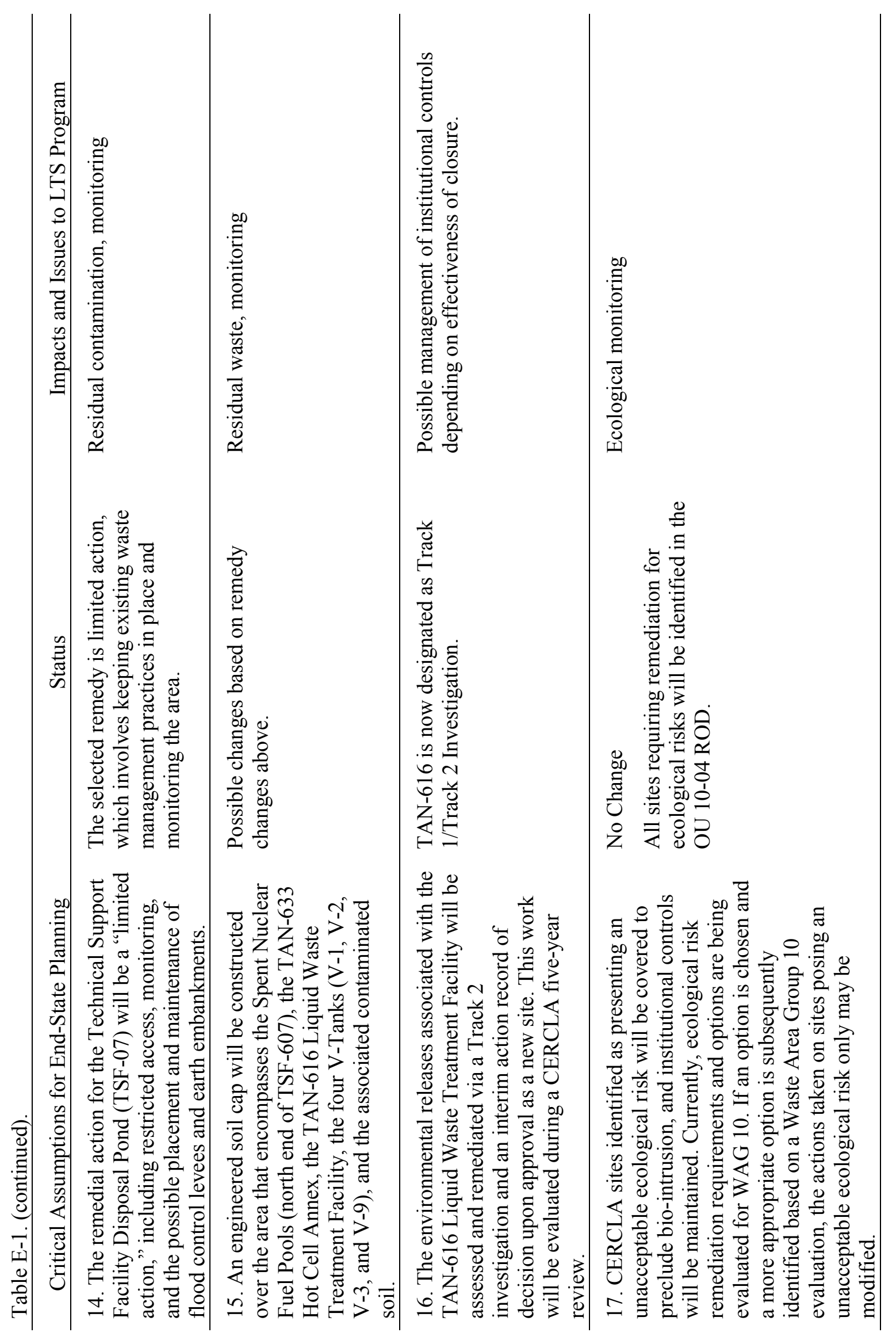




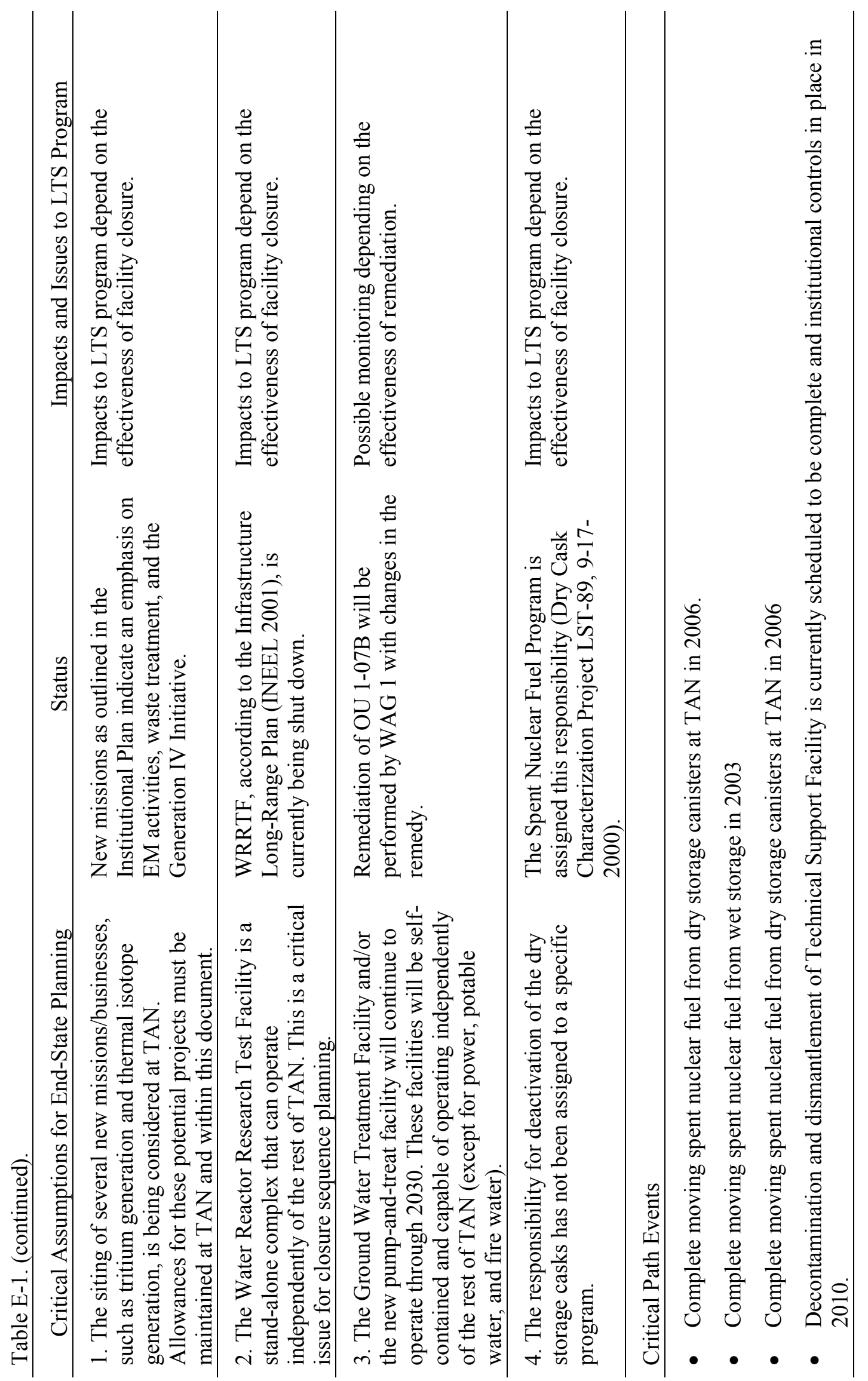




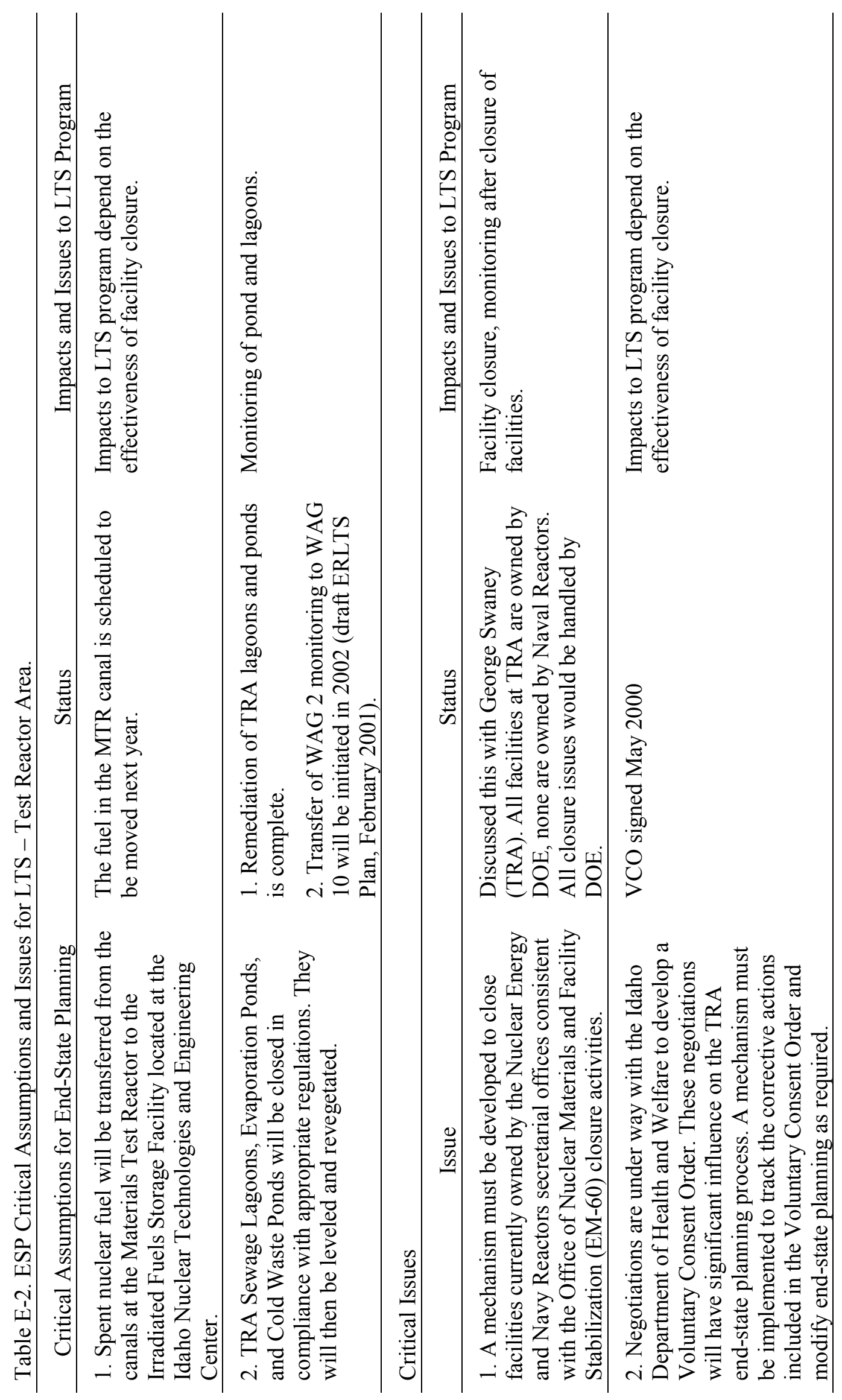




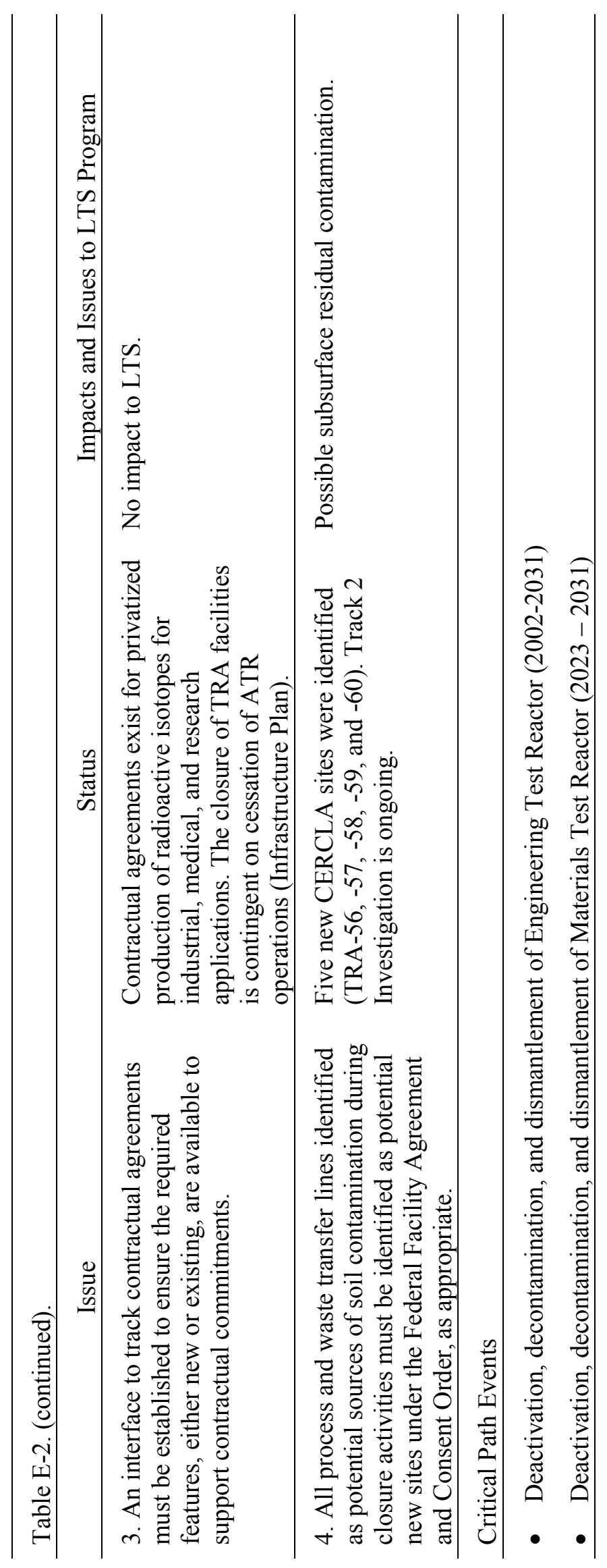

E-10 


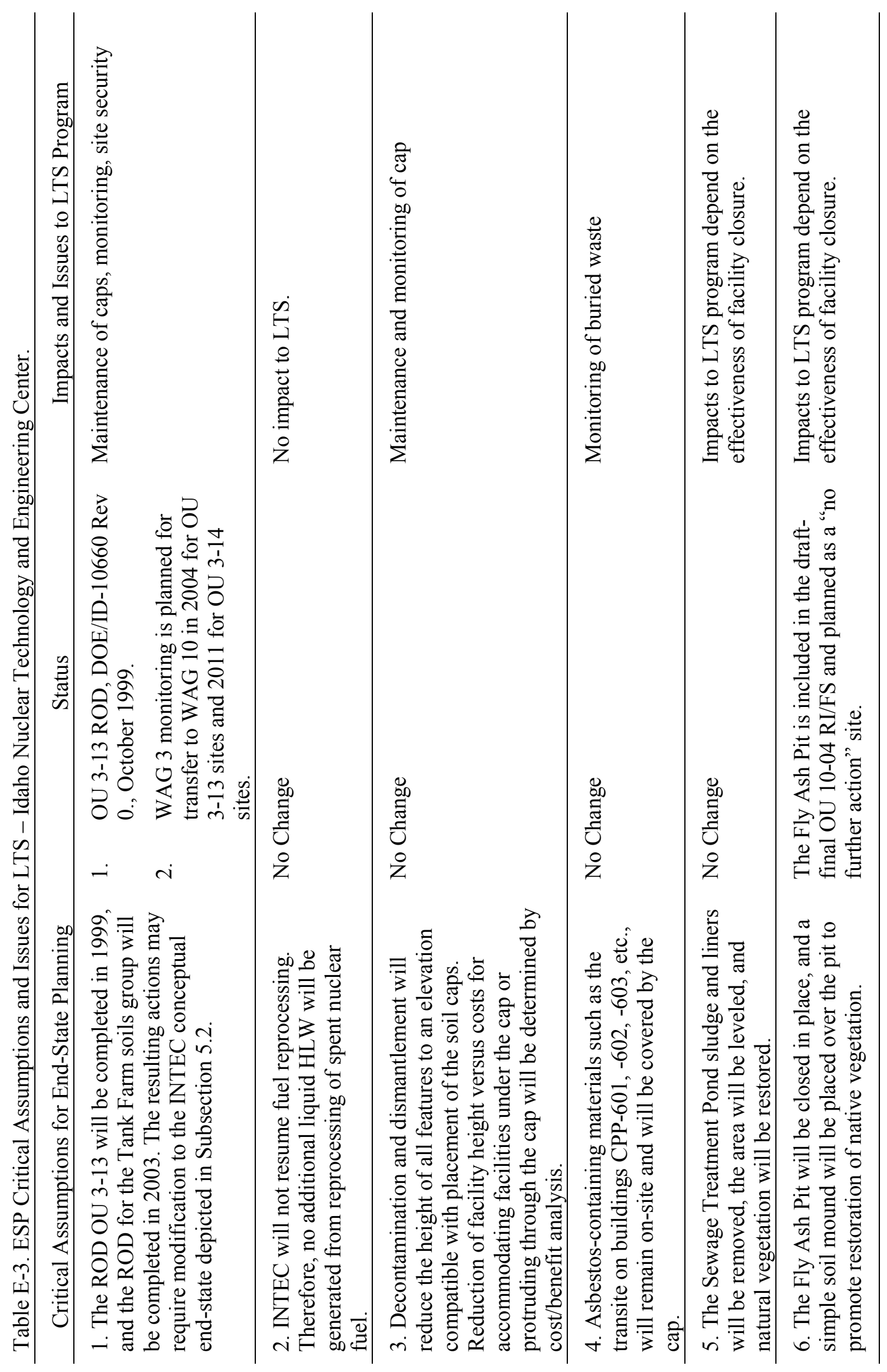




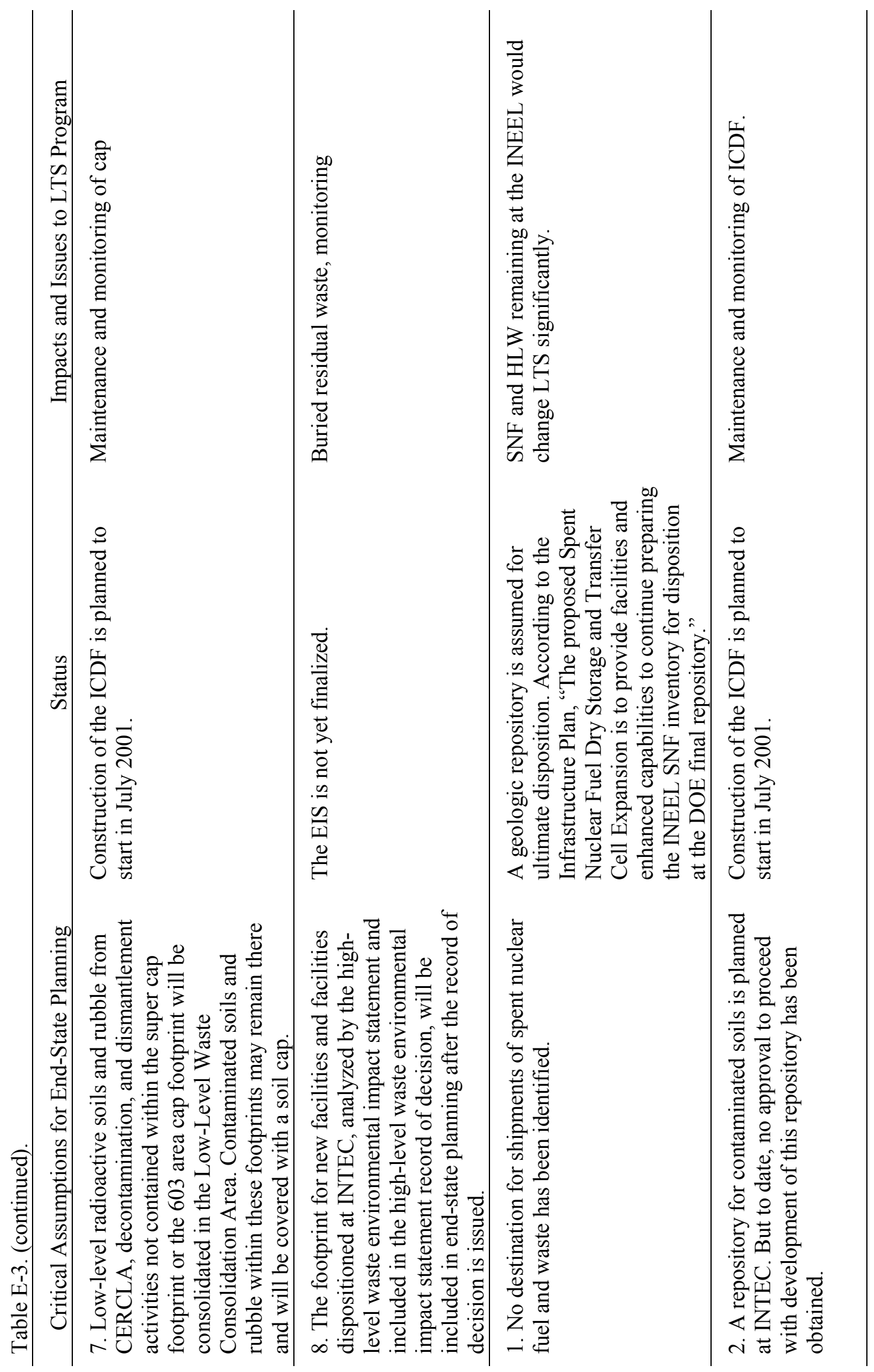




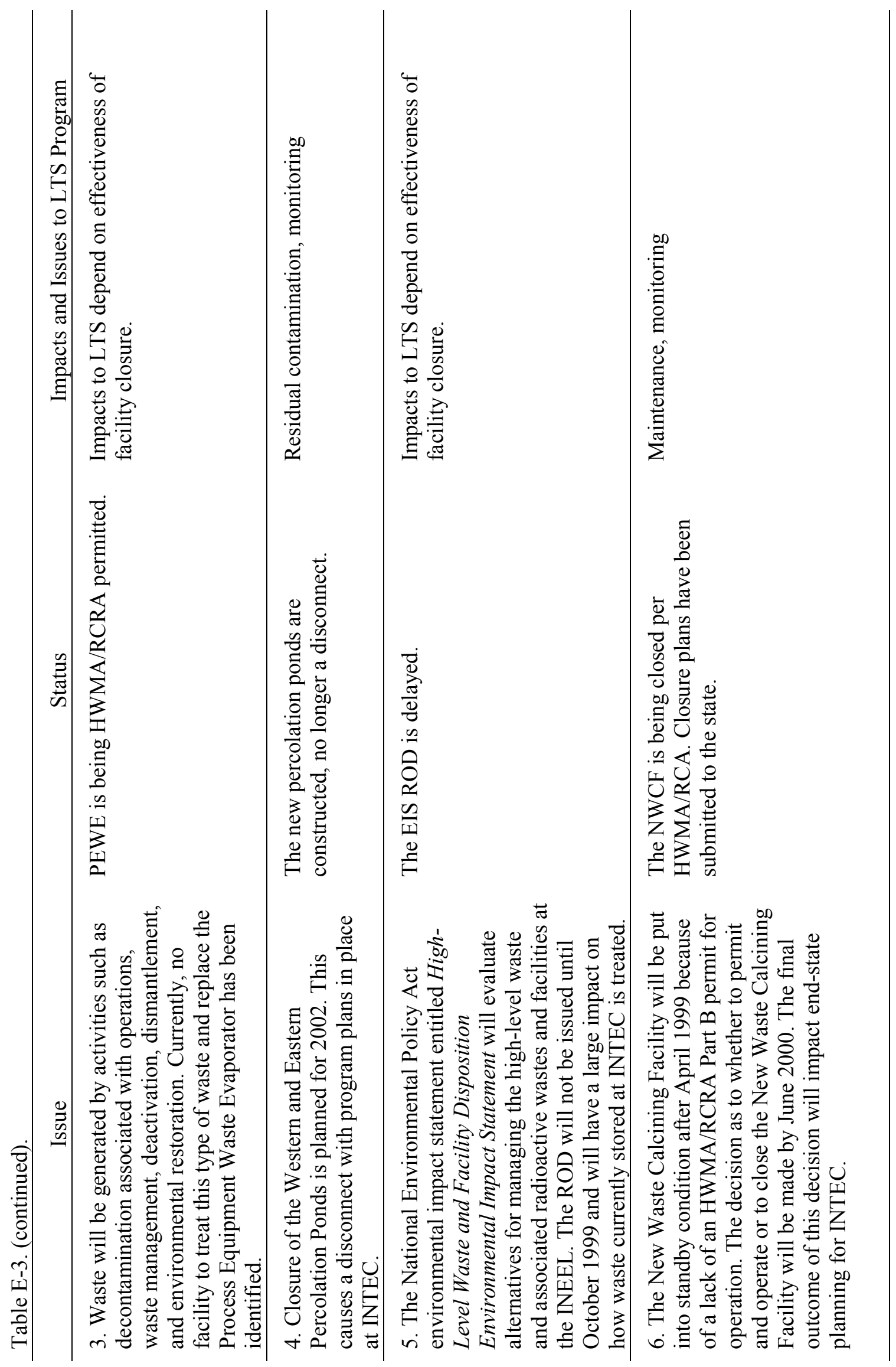




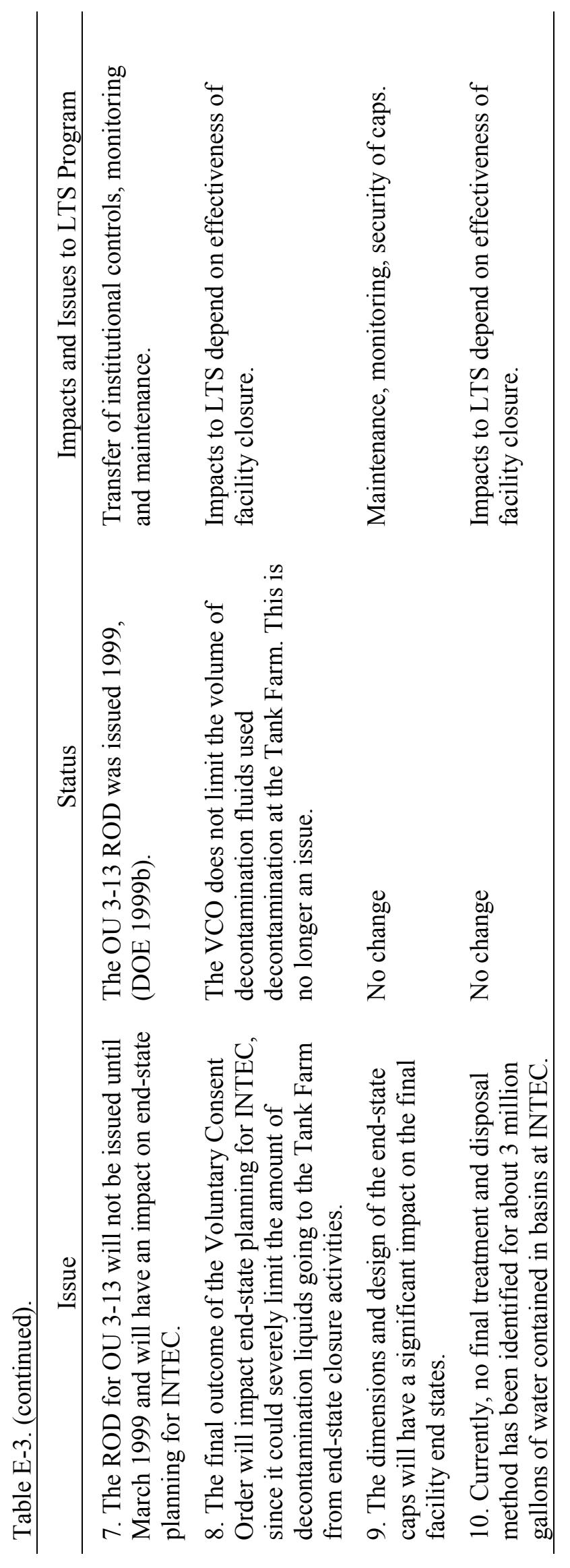

E-14 


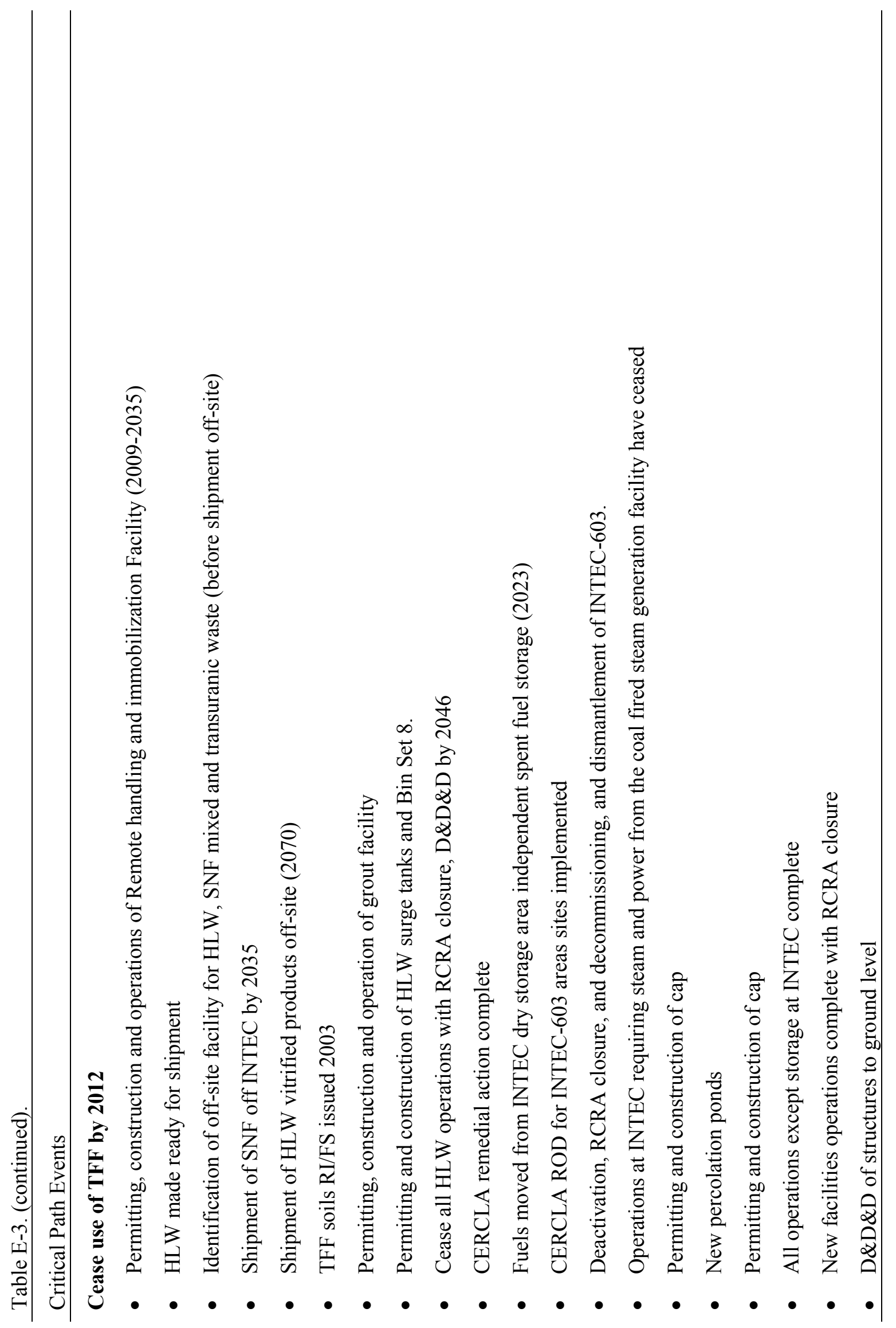




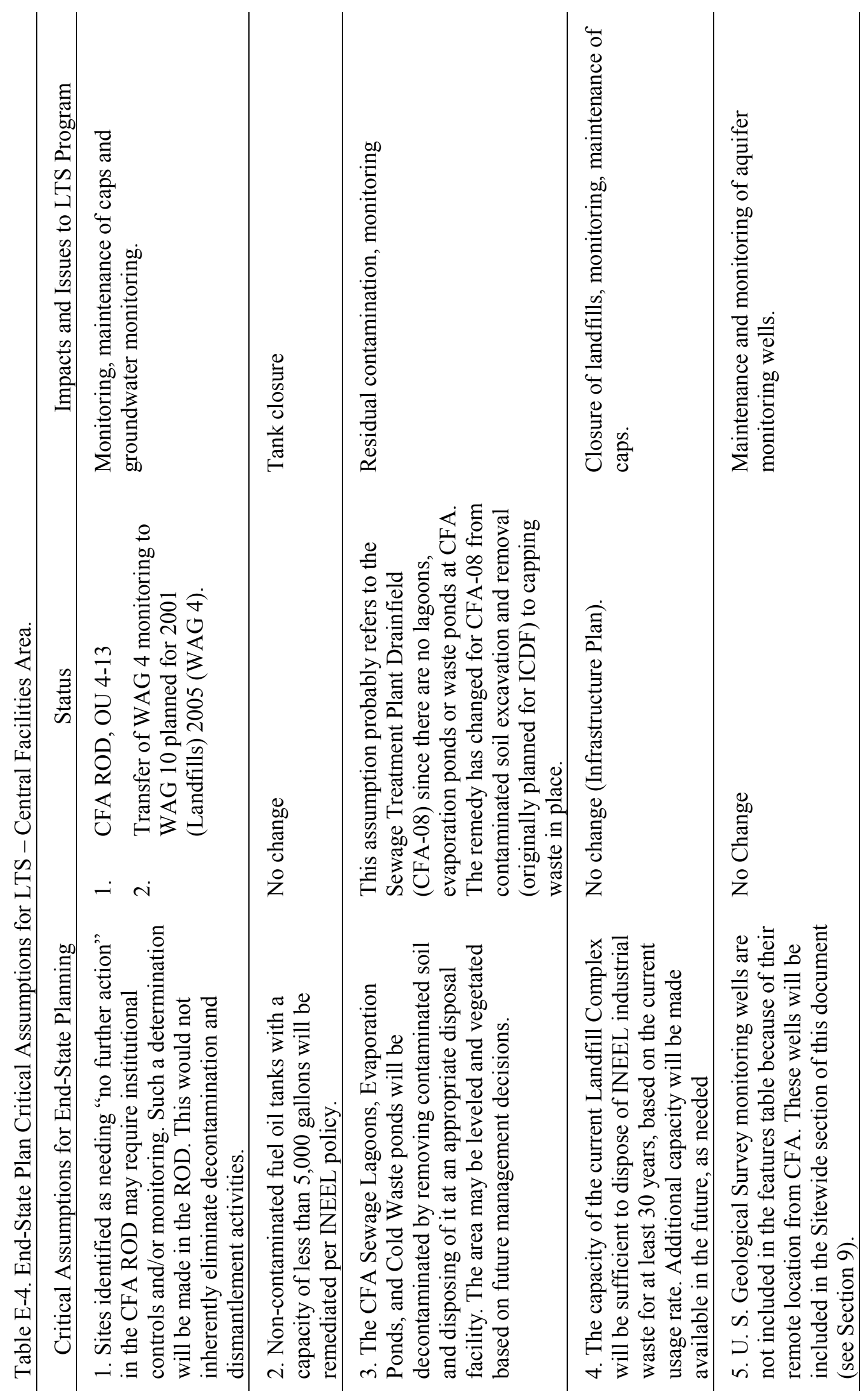




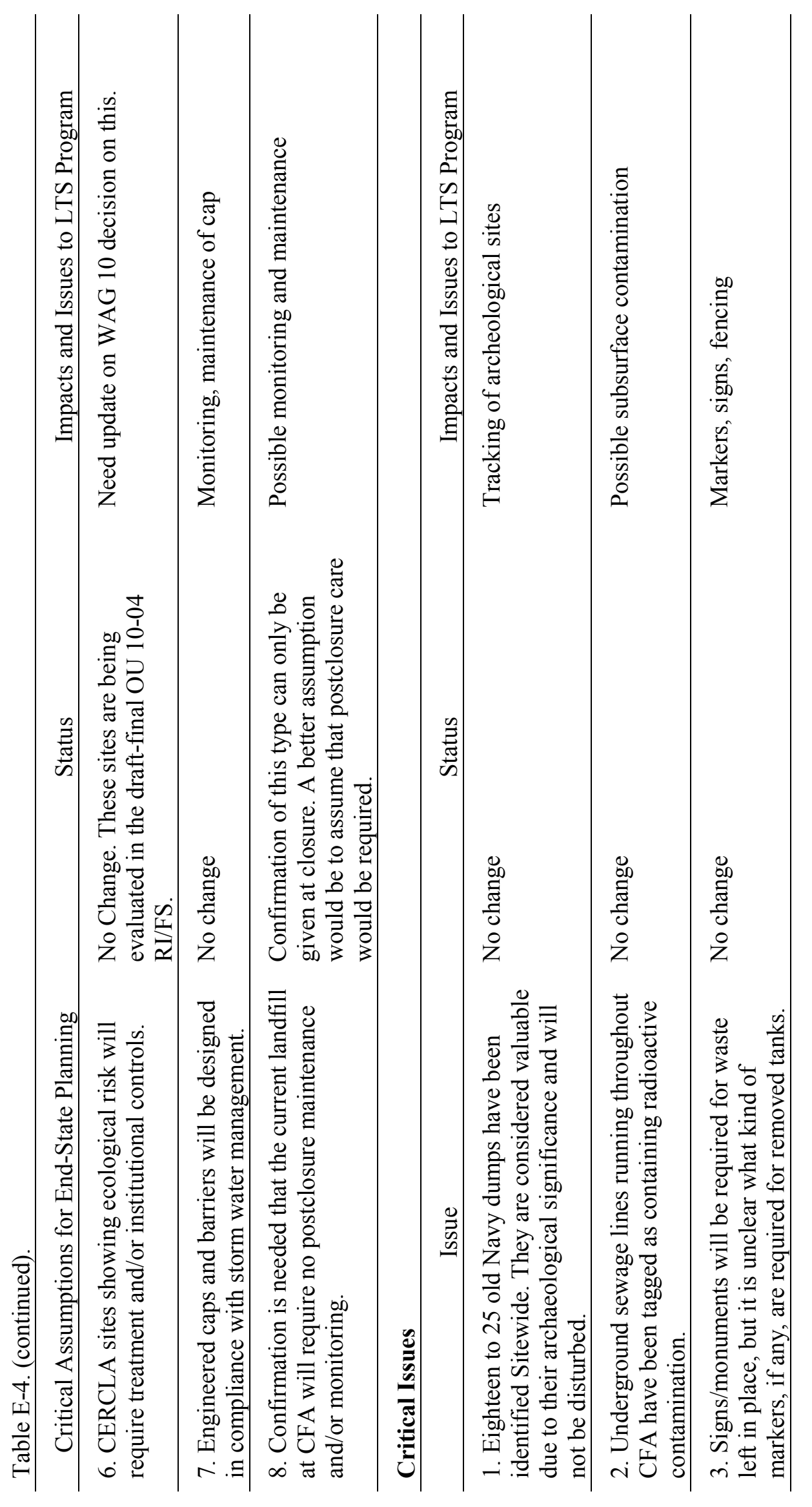




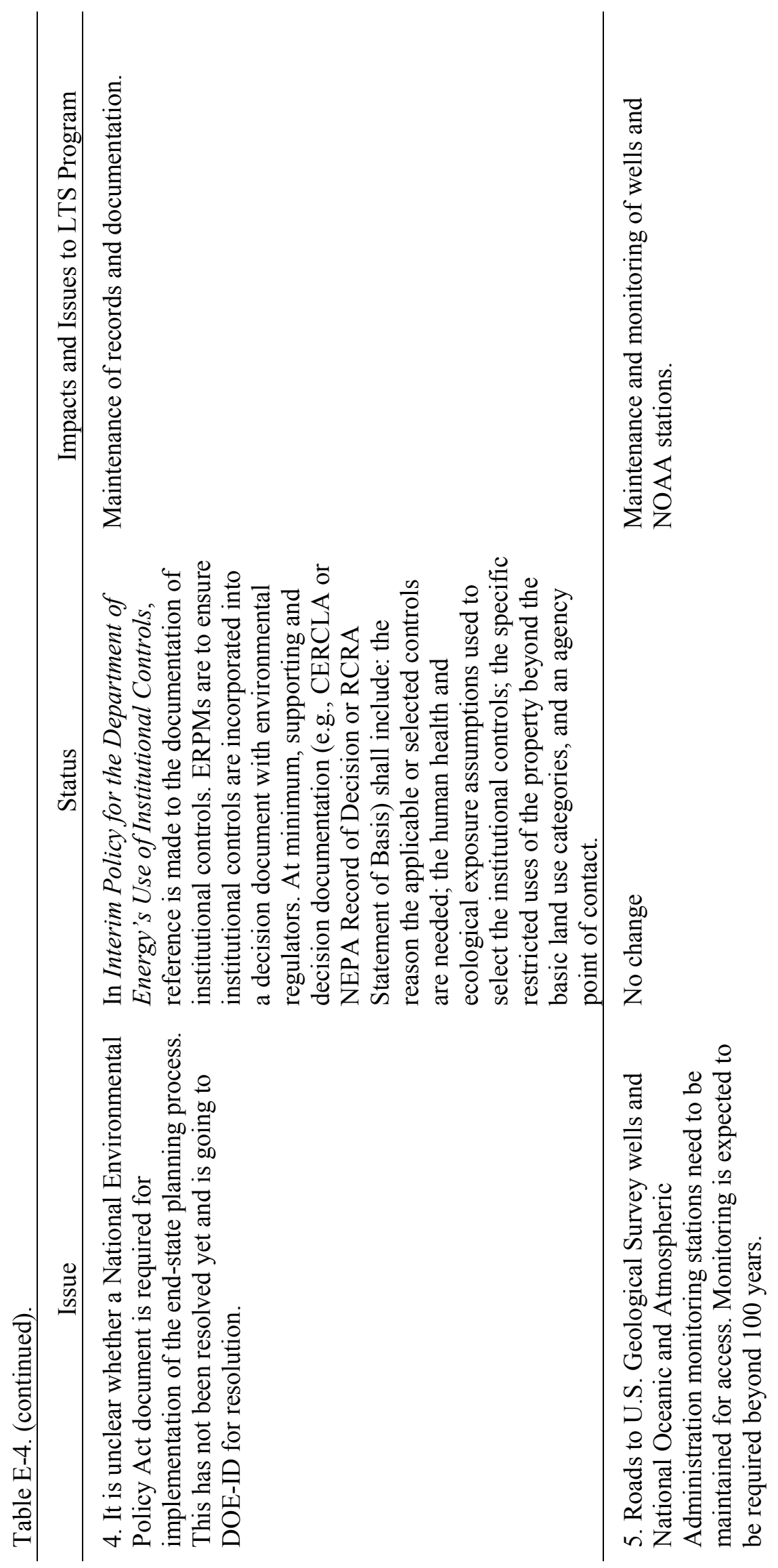




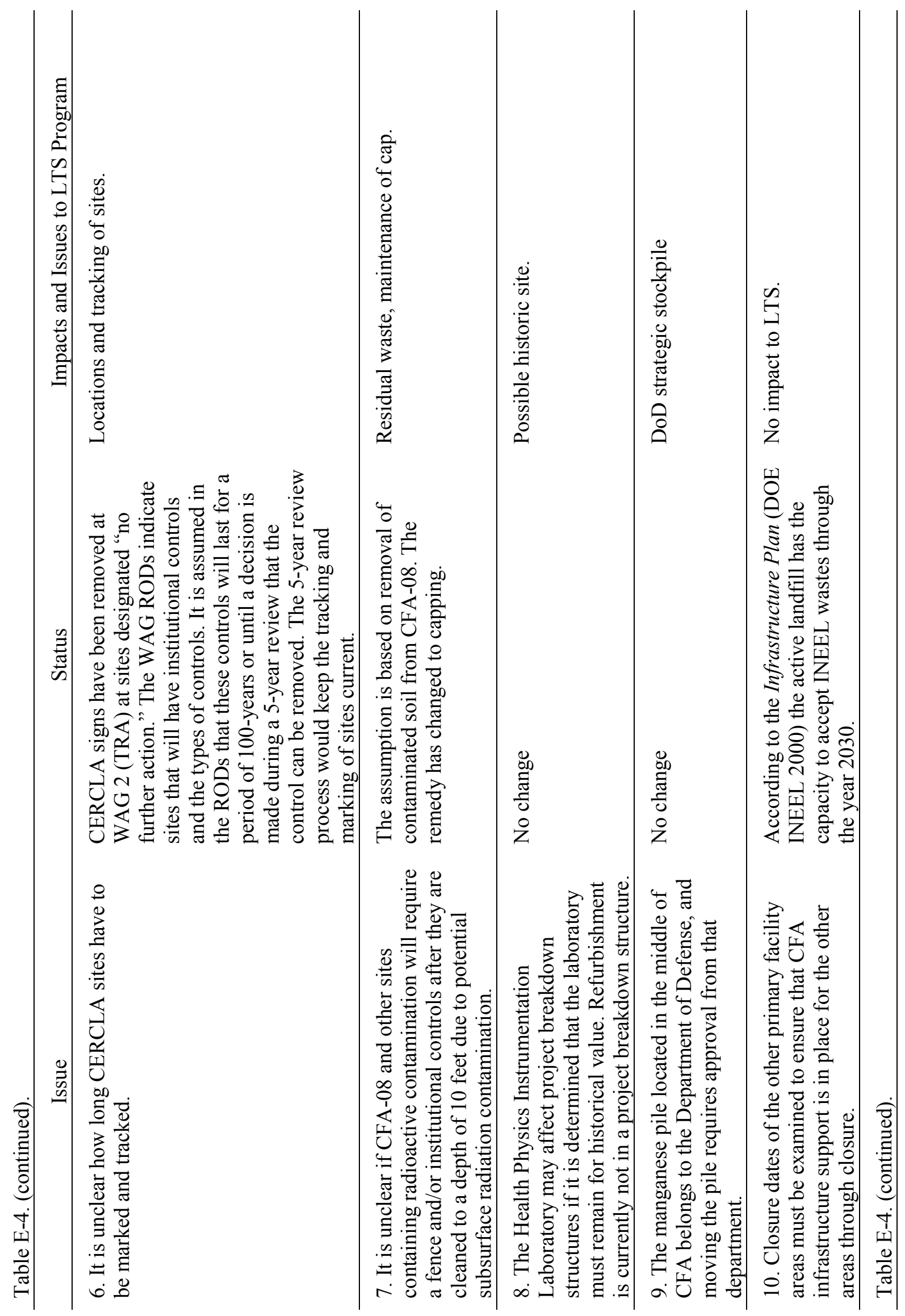




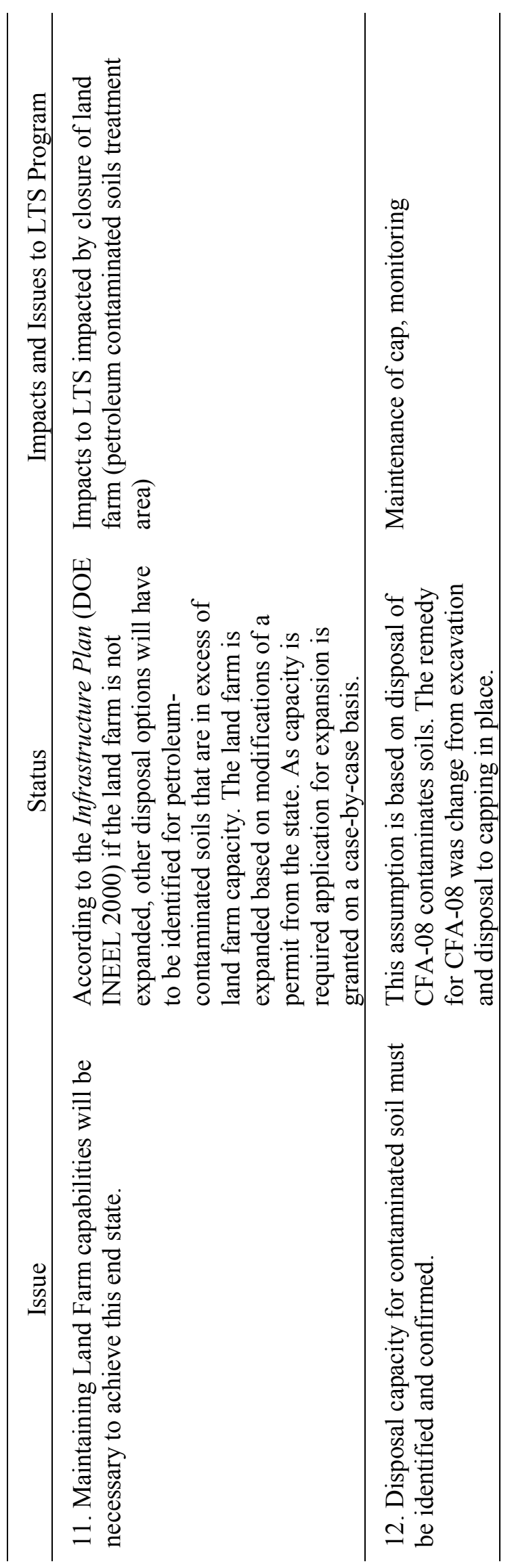




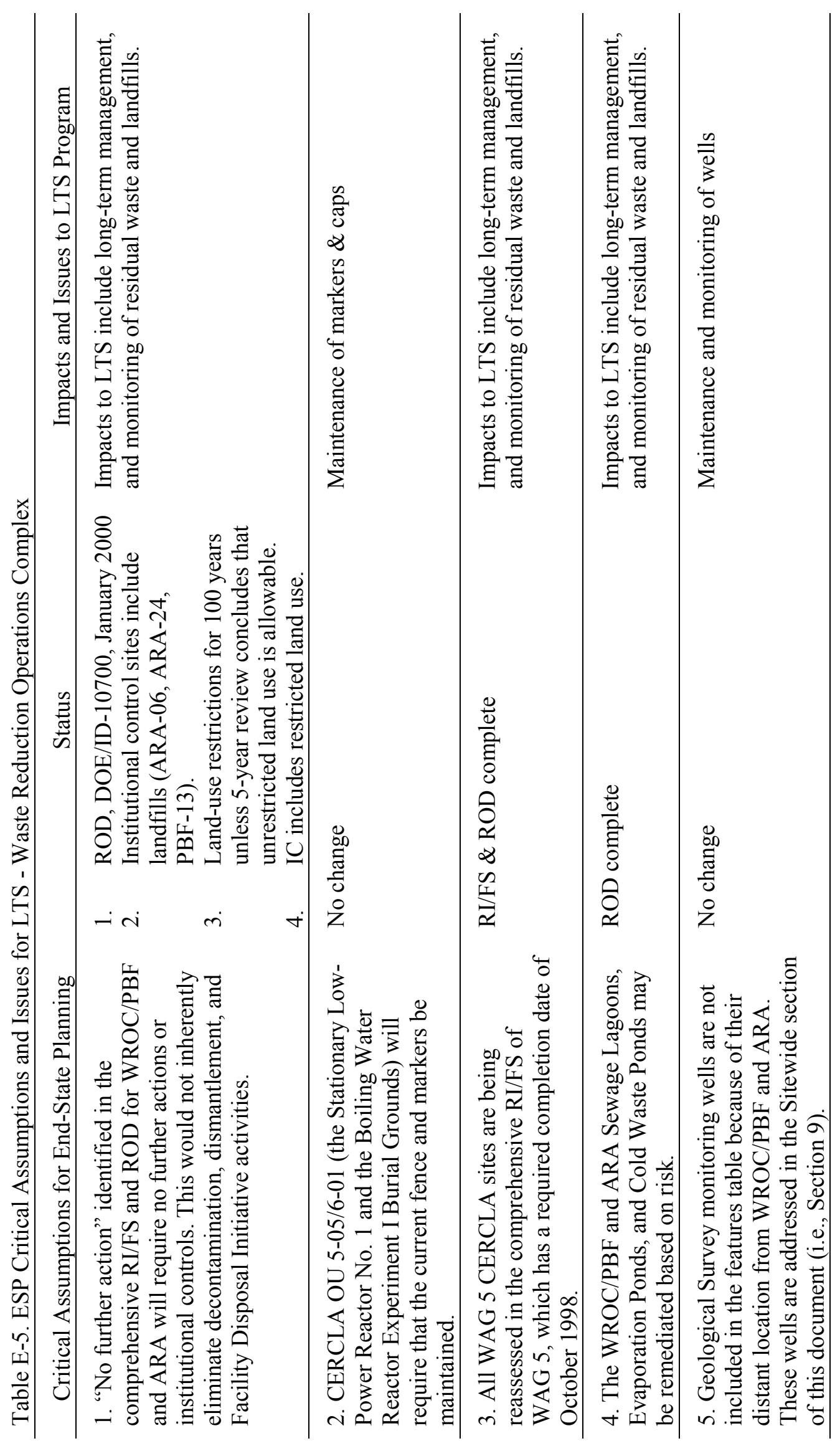




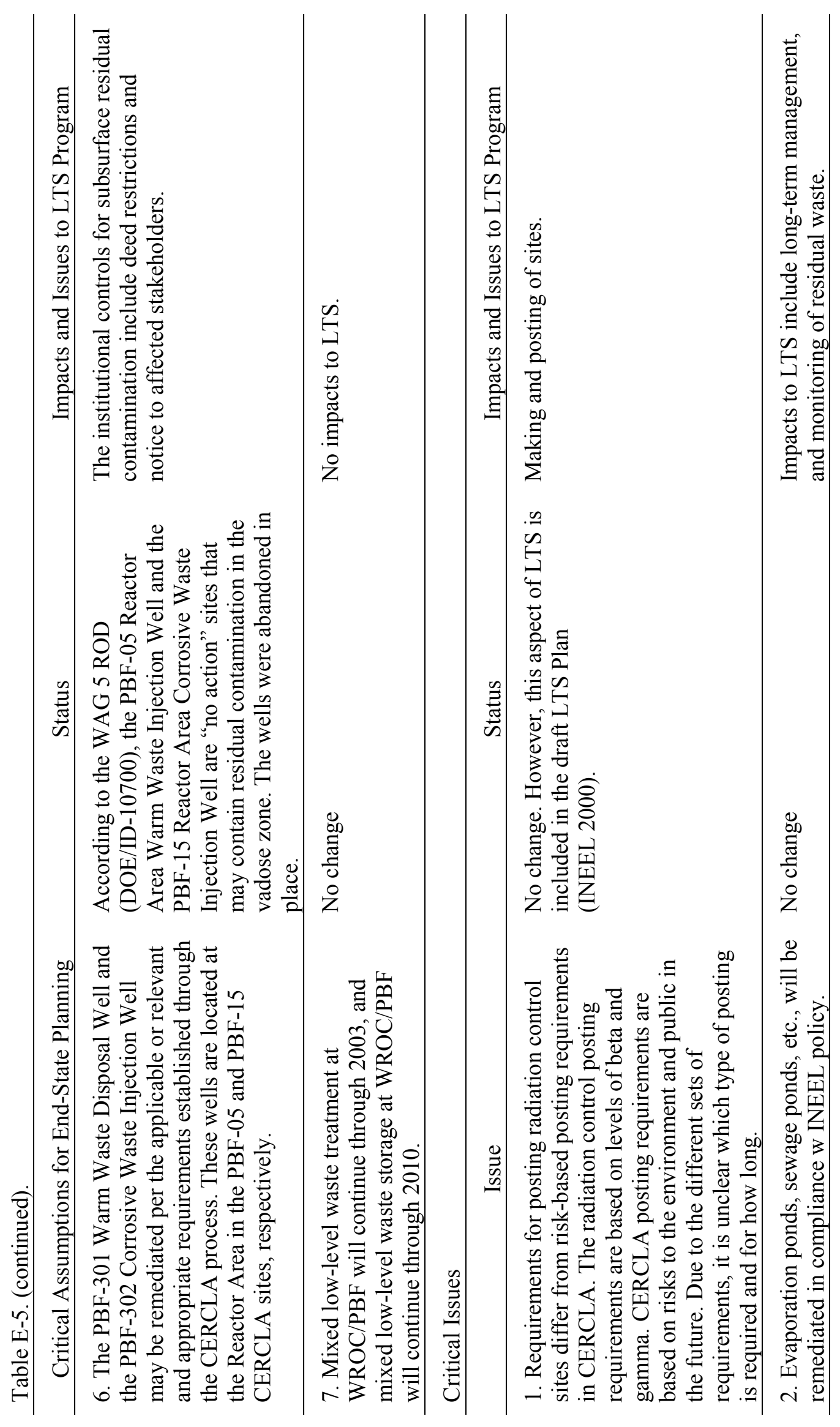




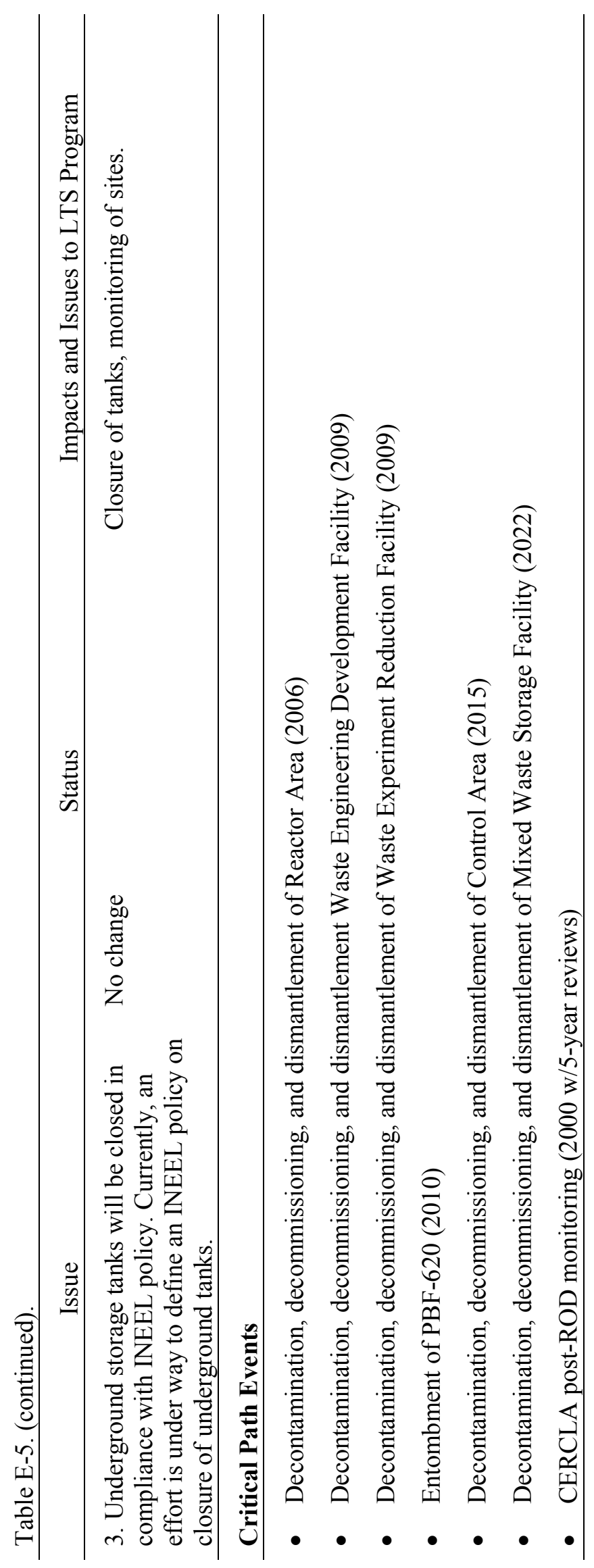

E-23 


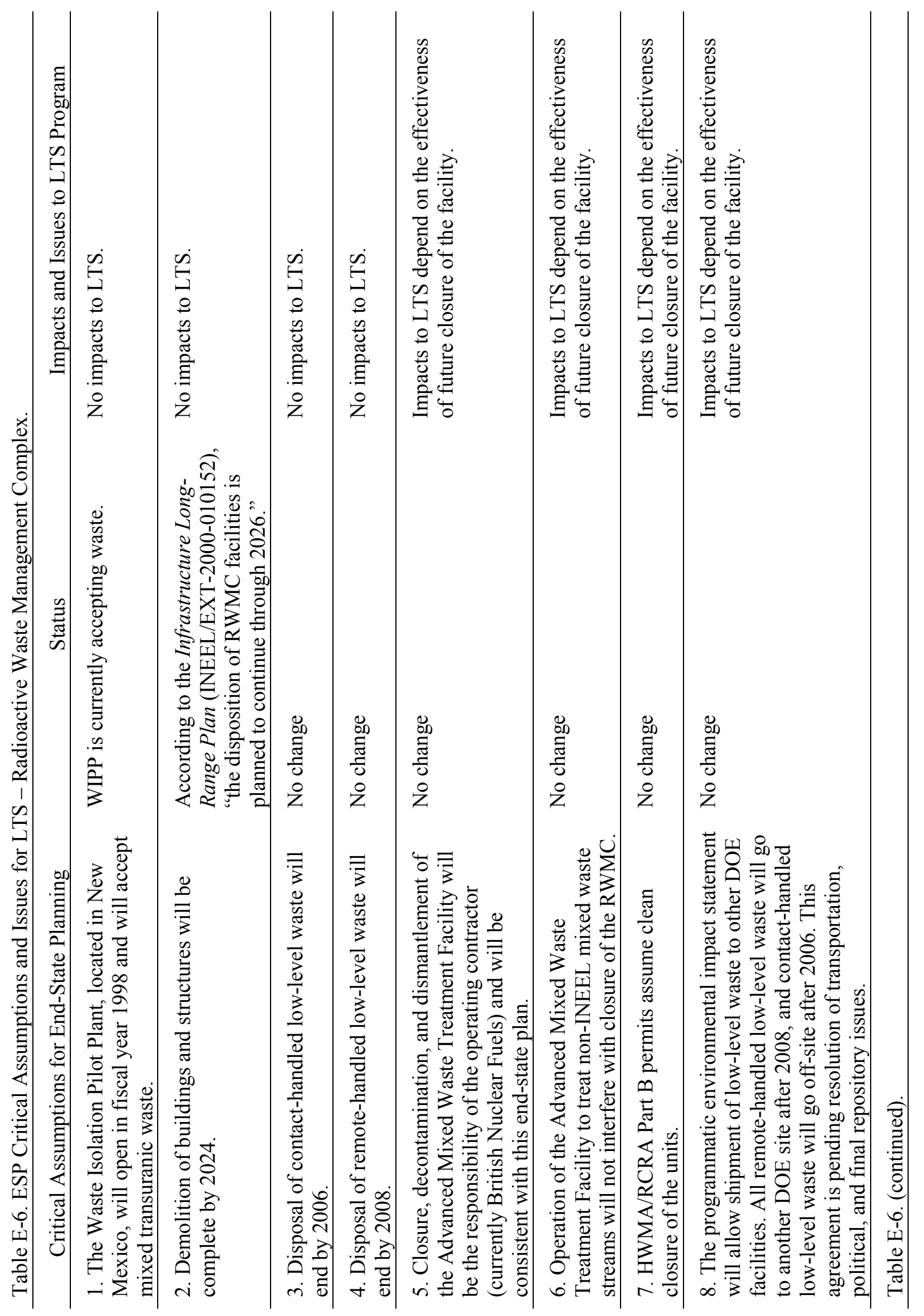




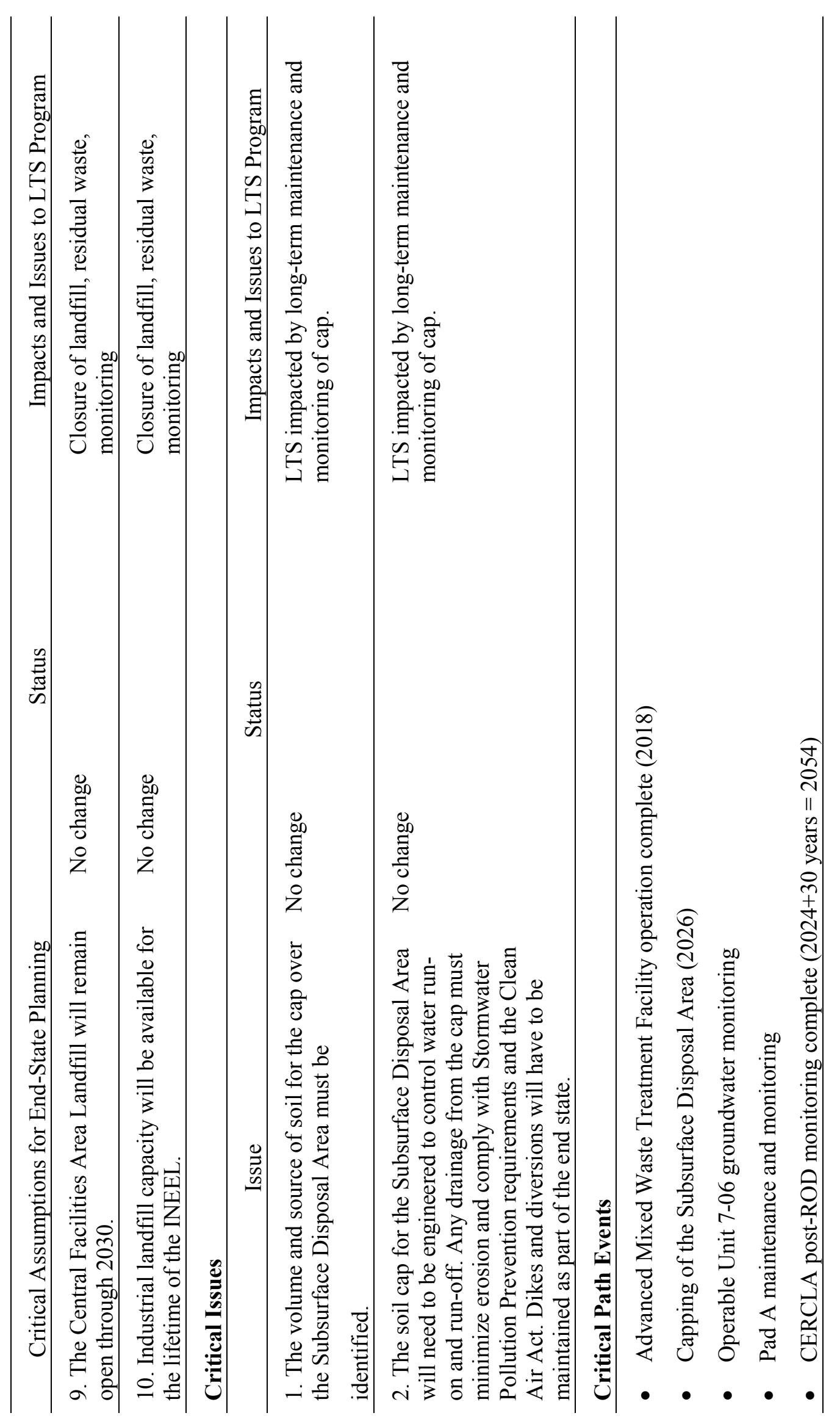




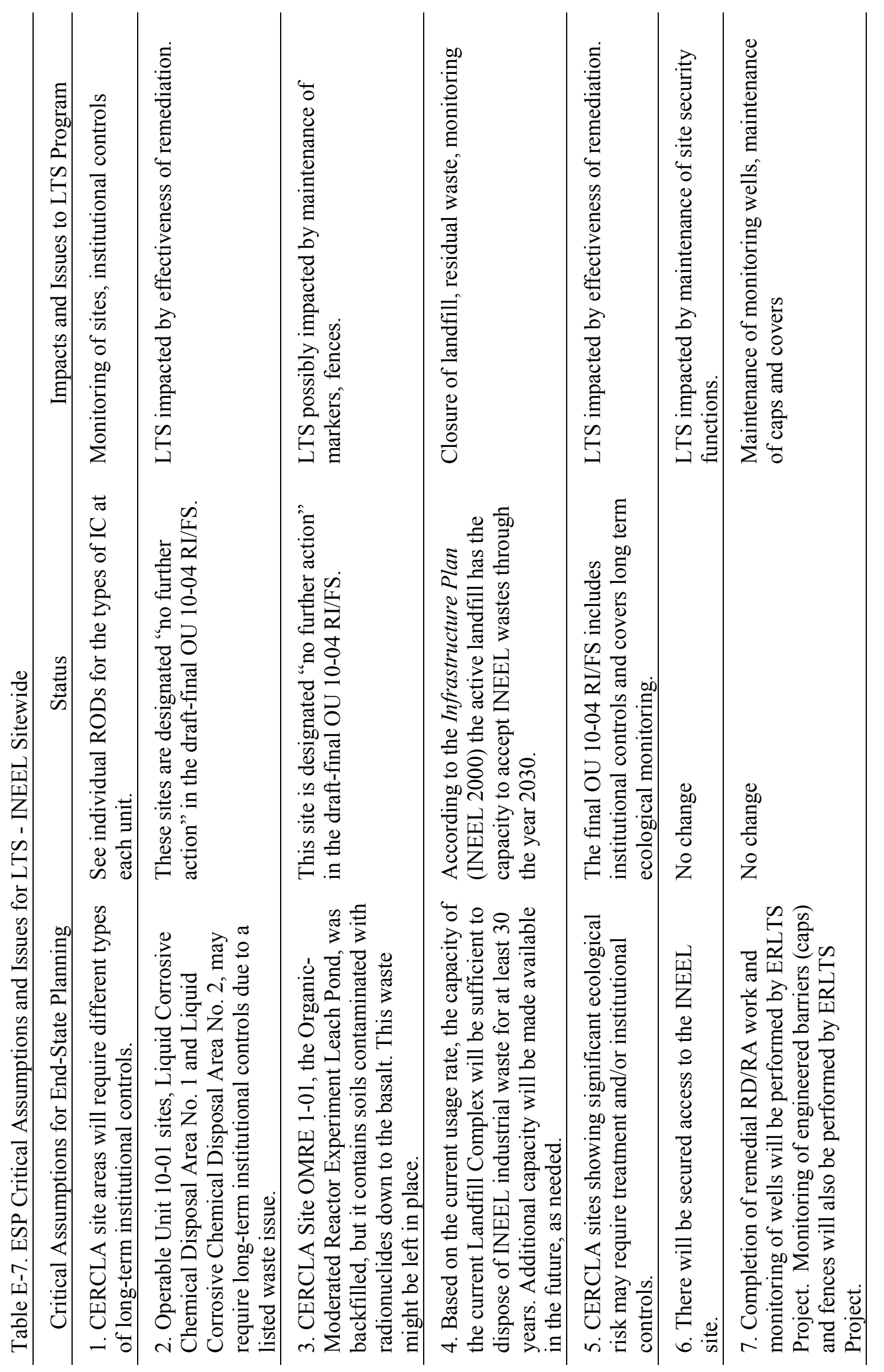




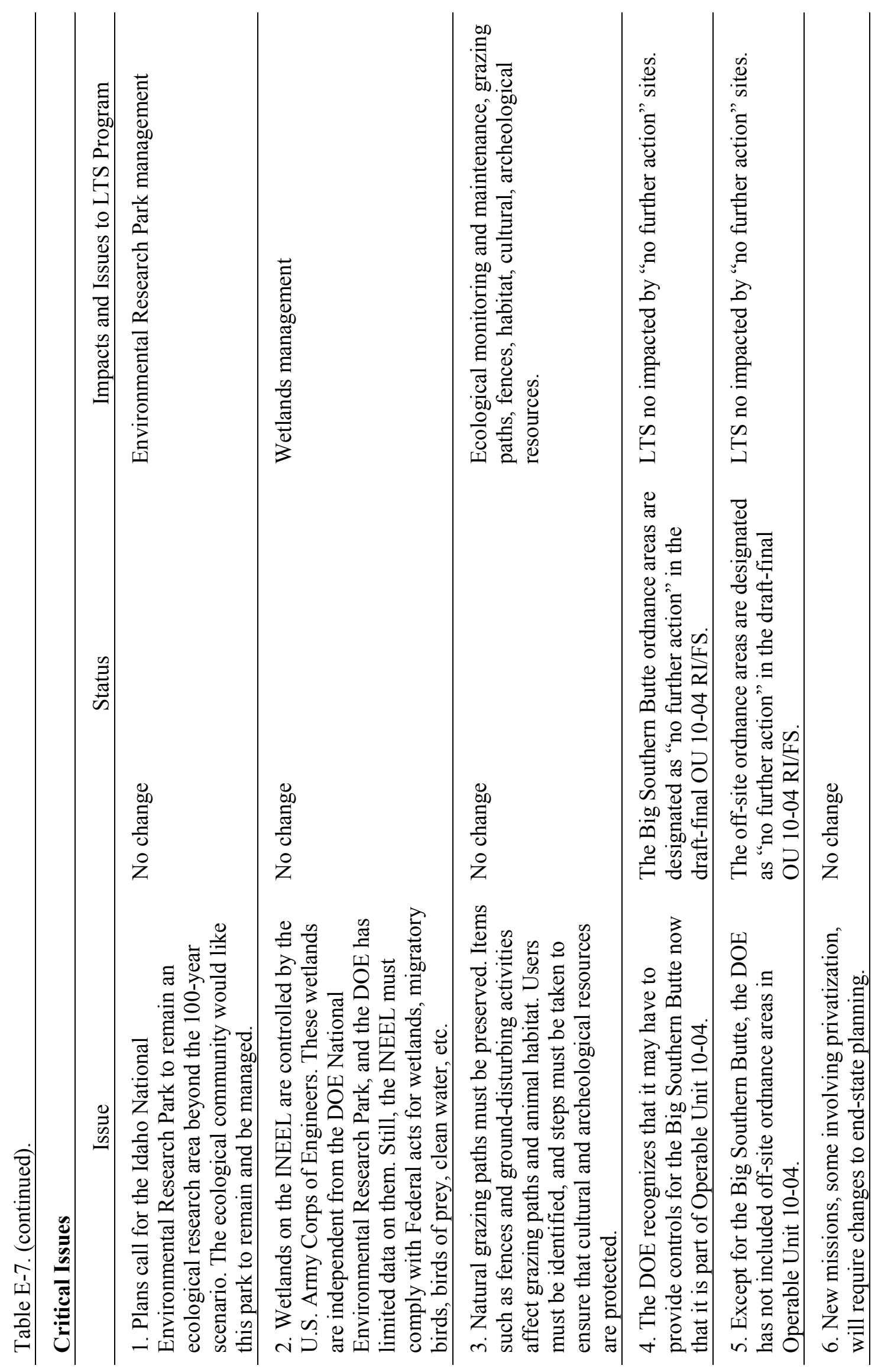




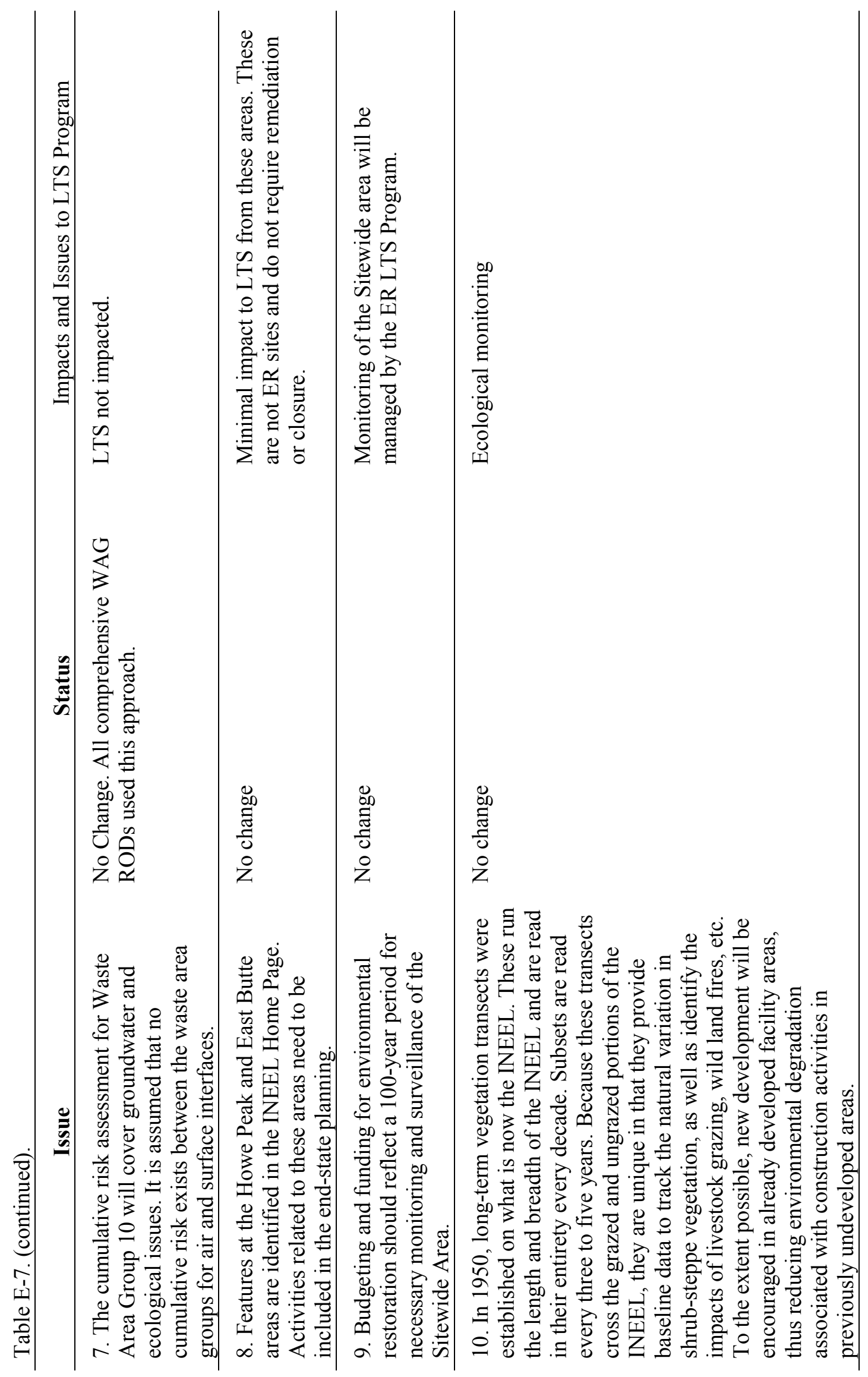




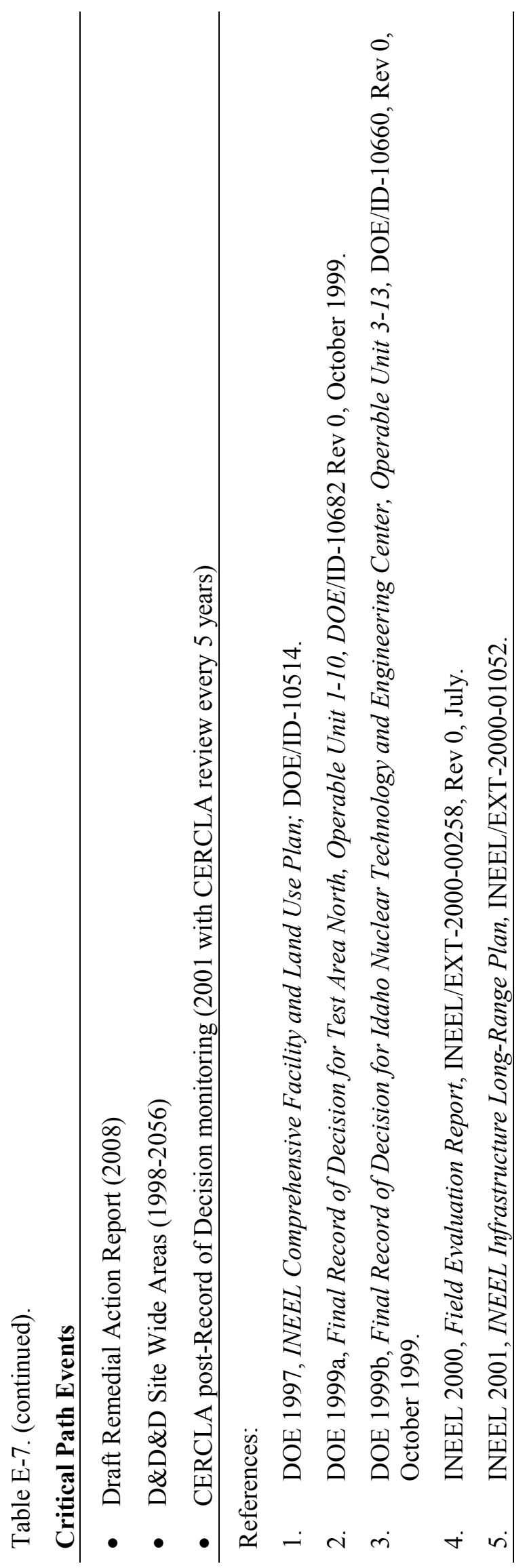




\section{Appendix F}

\section{Example Documentation to Identify LTS Transition Criteria}


F-2 


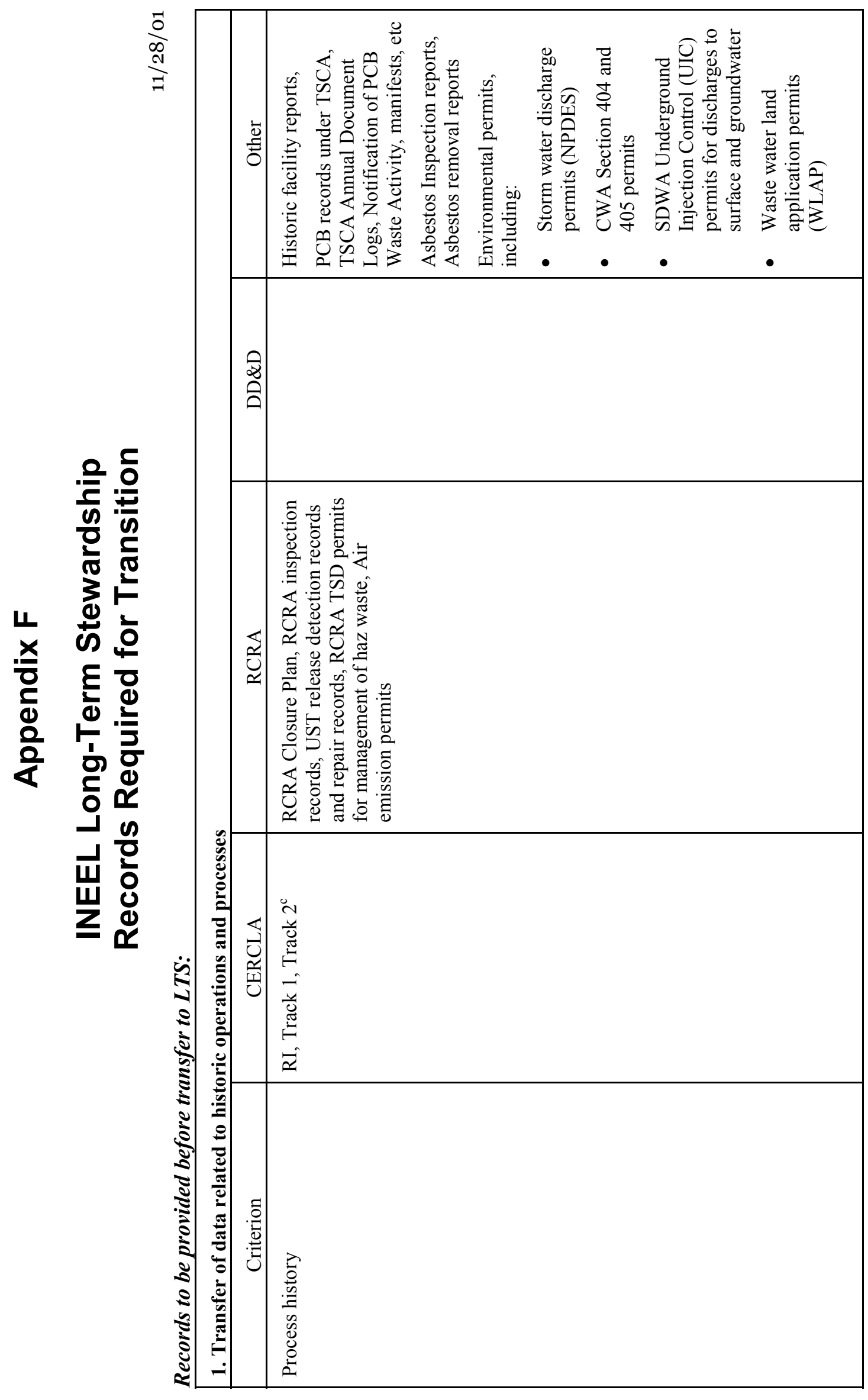

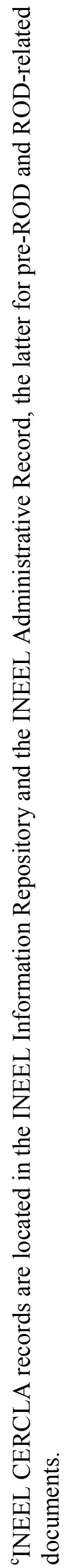




\begin{tabular}{|c|c|c|c|c|c|c|c|c|c|}
\hline & $\begin{array}{l}\overline{ \pm} \\
\stackrel{ \pm}{0}\end{array}$ & 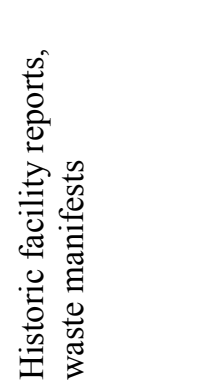 & 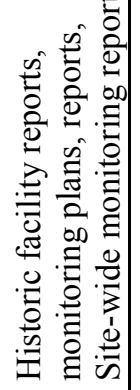 & 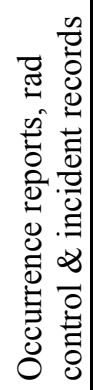 & 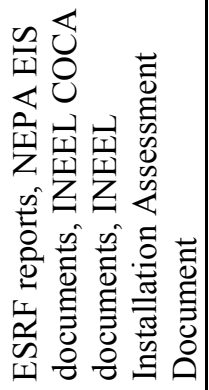 & & 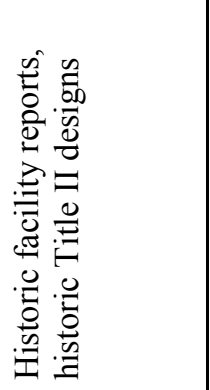 & $\underset{\text { S }}{\stackrel{S}{S}}$ & 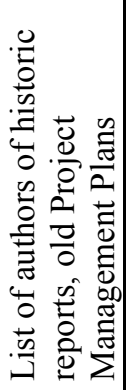 \\
\hline & $\begin{array}{l}2 \\
\hat{2} \\
\hat{0}\end{array}$ & 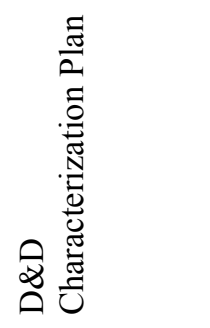 & 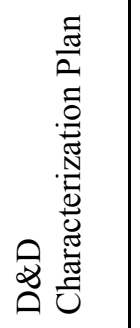 & 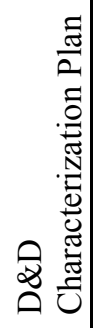 & & 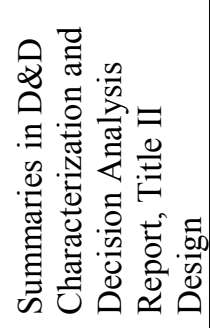 & 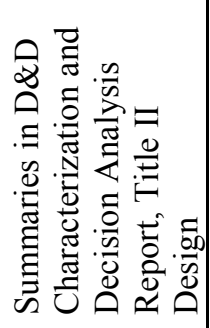 & 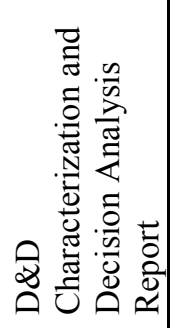 & \\
\hline & $\begin{array}{l}\mathbb{\Omega} \\
\underset{\sim}{\approx} \\
\end{array}$ & 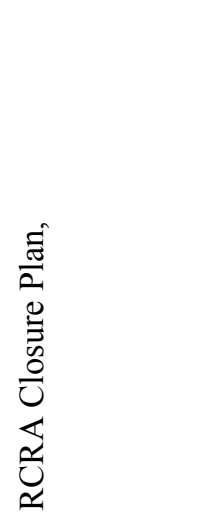 & 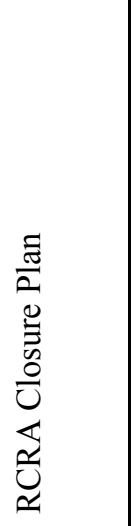 & 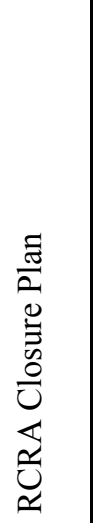 & 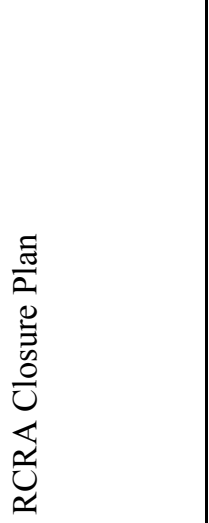 & 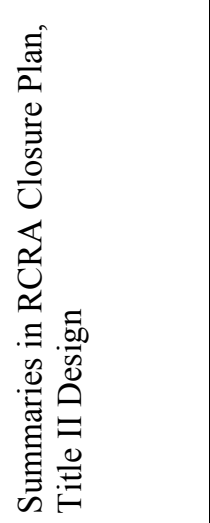 & 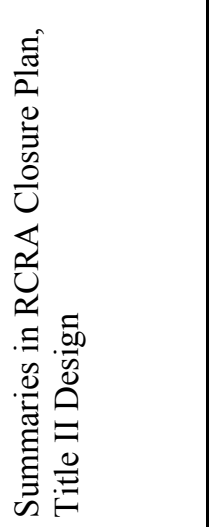 & 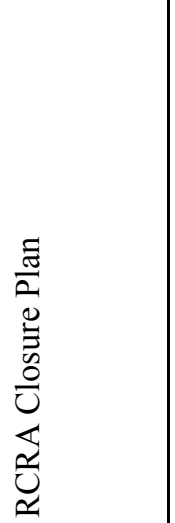 & \\
\hline 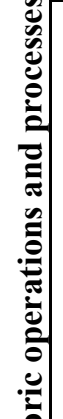 & 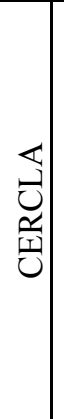 & 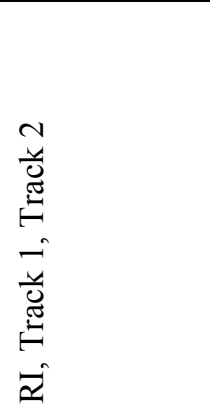 & 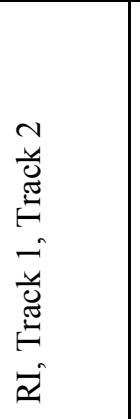 & 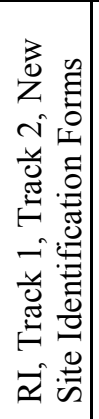 & 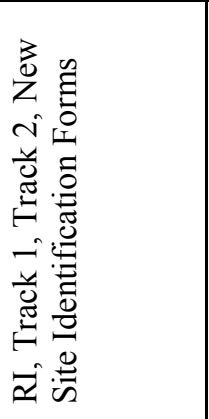 & 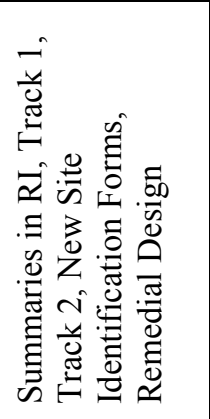 & 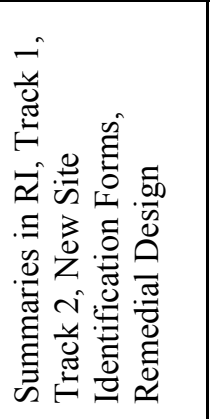 & 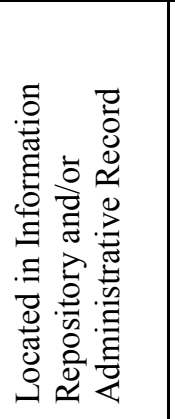 & \\
\hline 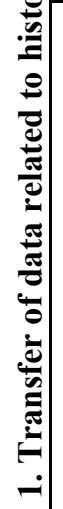 & |ี & 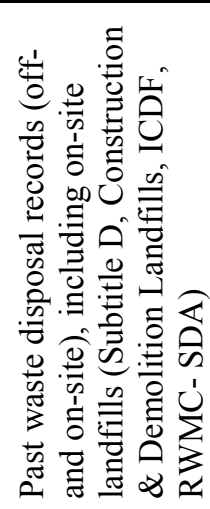 & 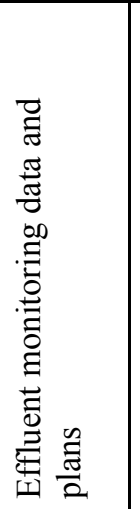 & 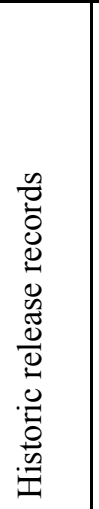 & 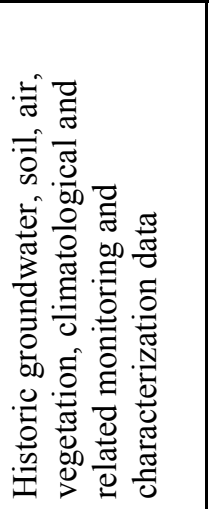 & 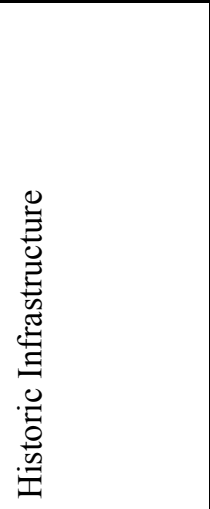 & 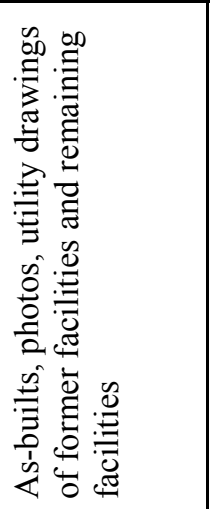 & 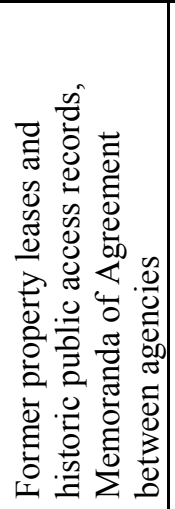 & 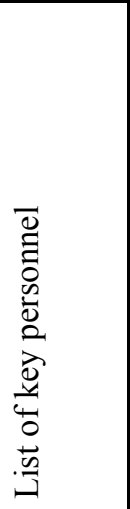 \\
\hline
\end{tabular}




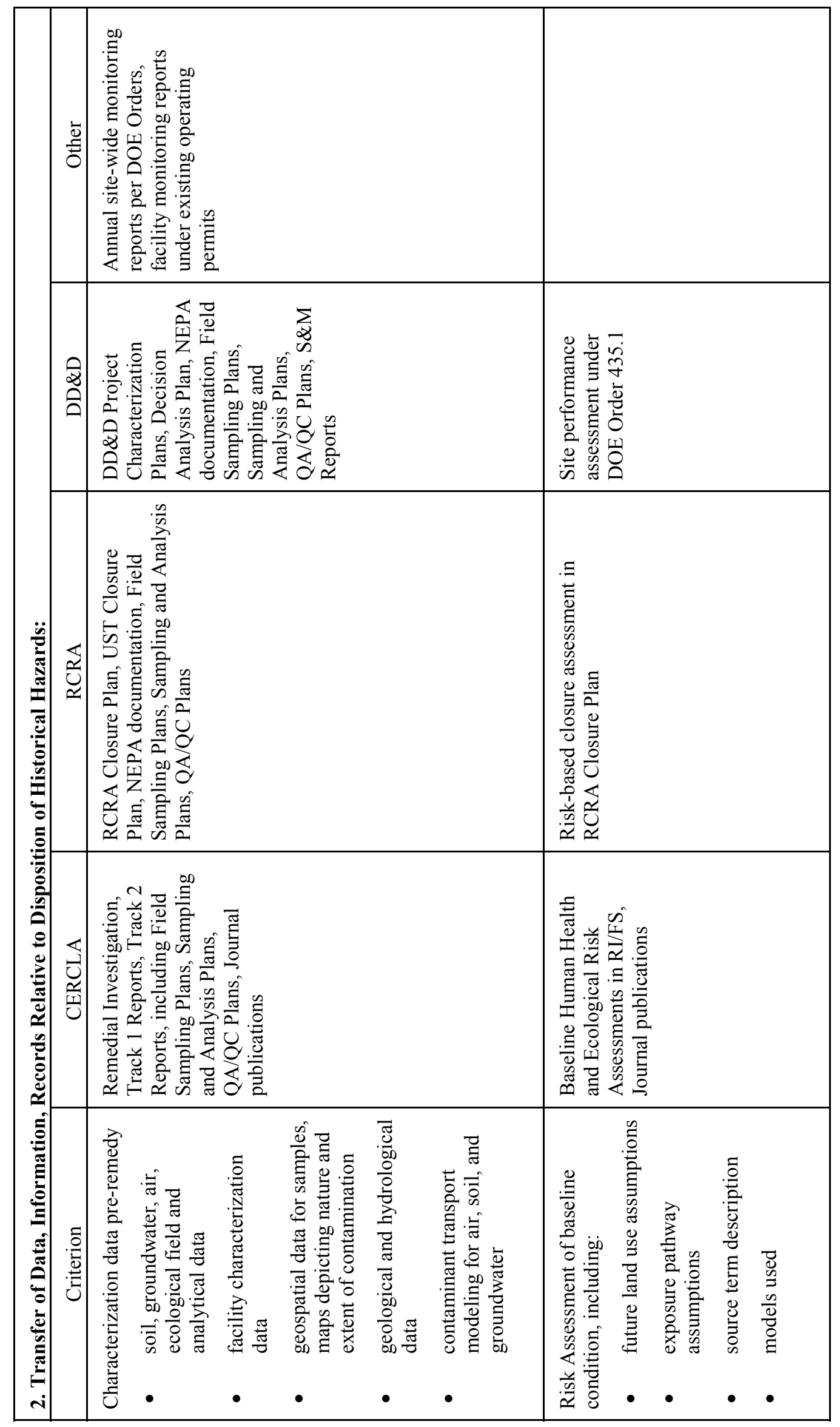




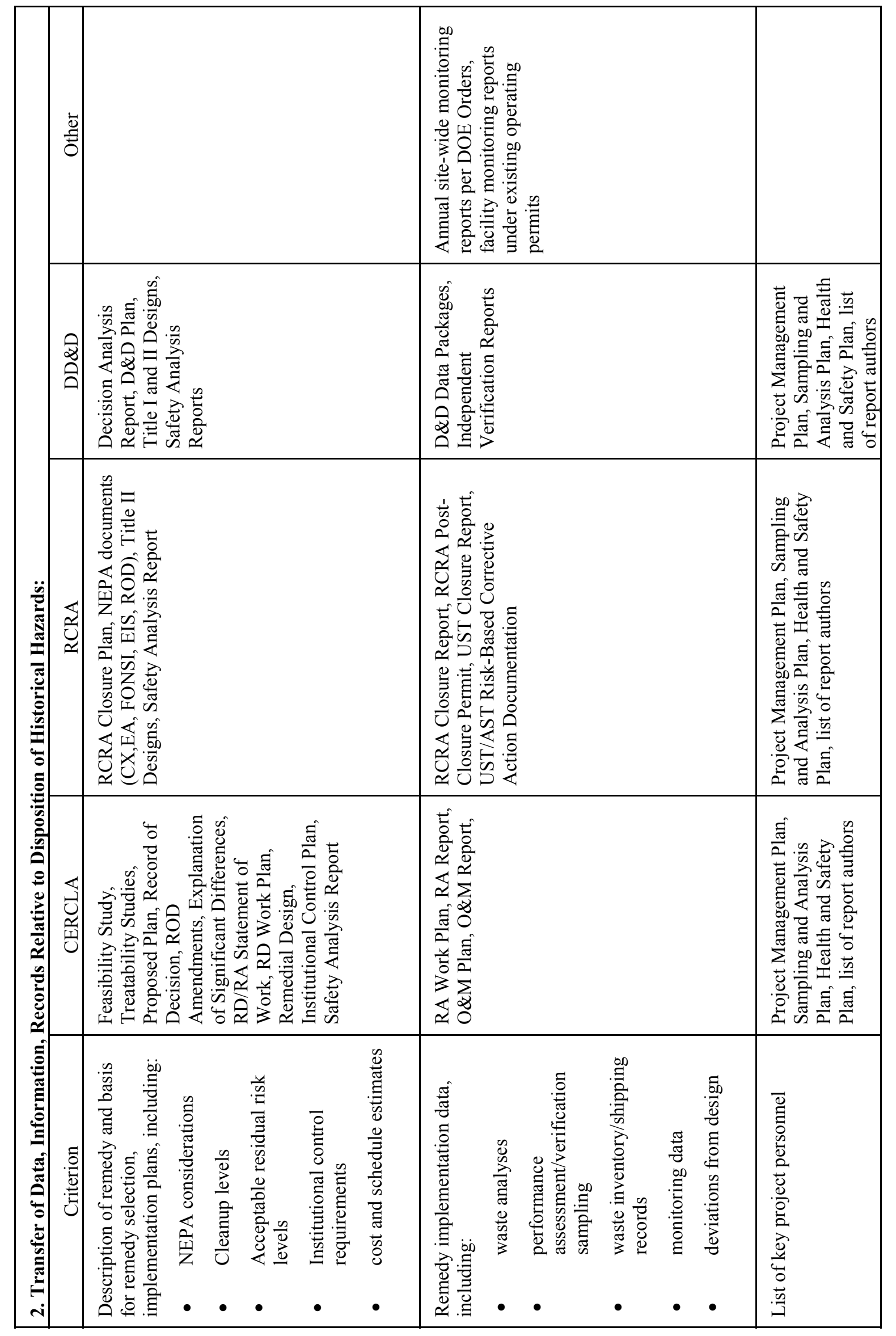

I 


\begin{tabular}{|c|c|c|c|c|c|}
\hline & & 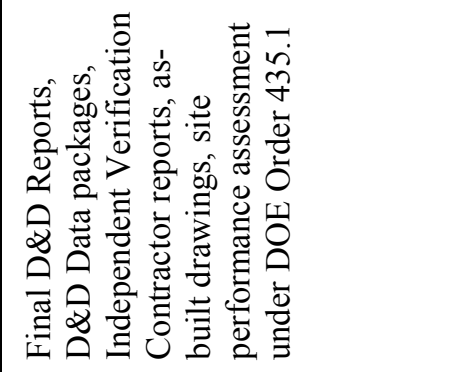 & 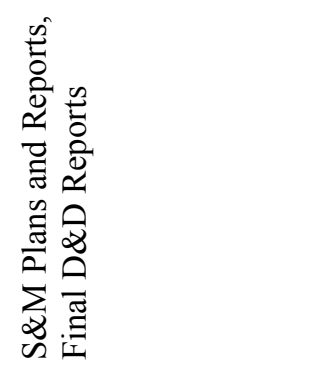 & 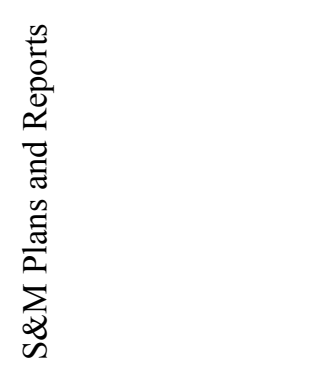 & 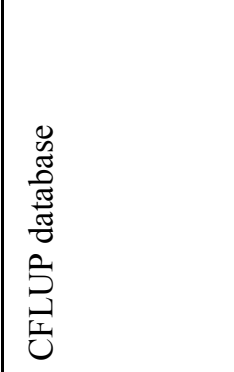 \\
\hline 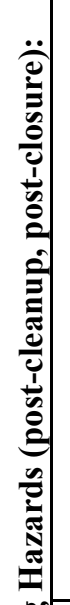 & & 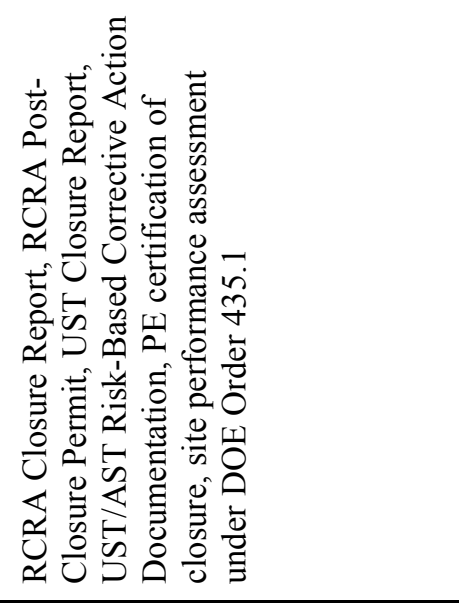 & 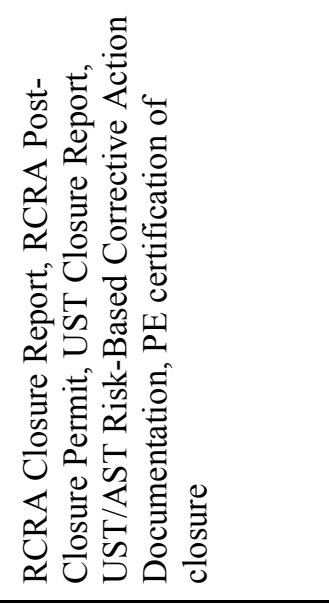 & 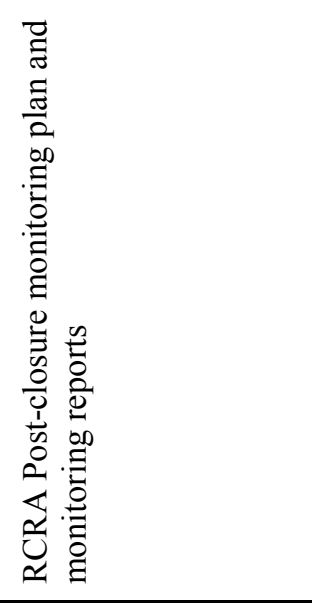 & 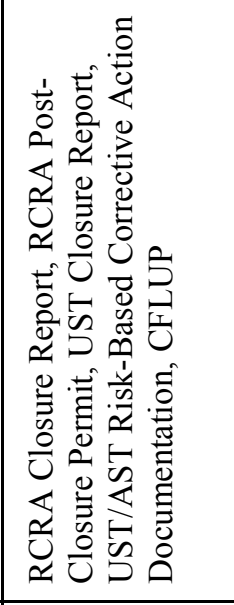 \\
\hline 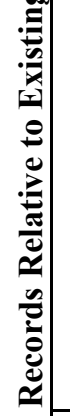 & & 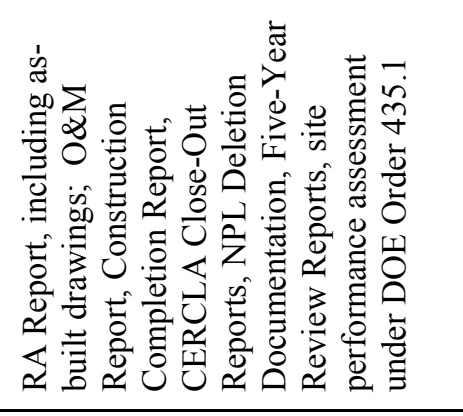 & 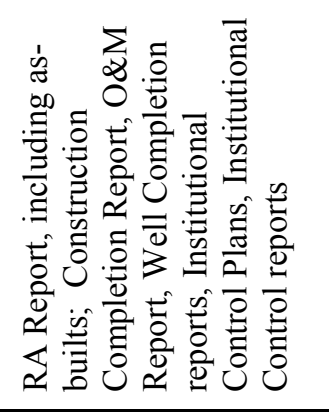 & 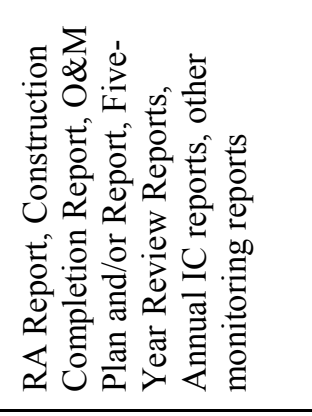 & 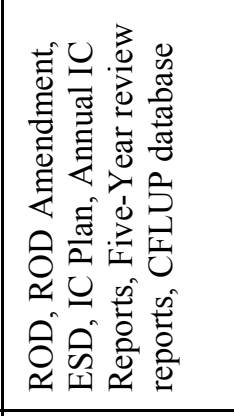 \\
\hline 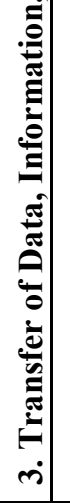 & & 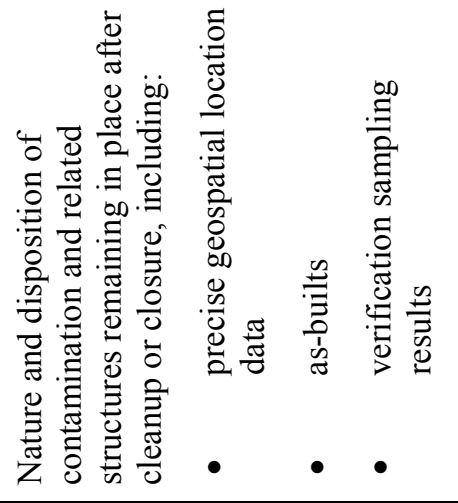 & 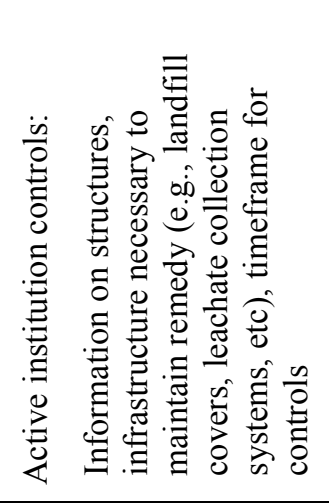 & 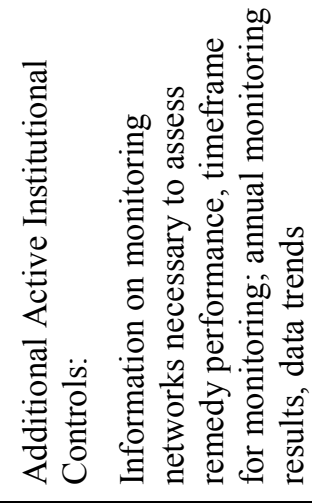 & 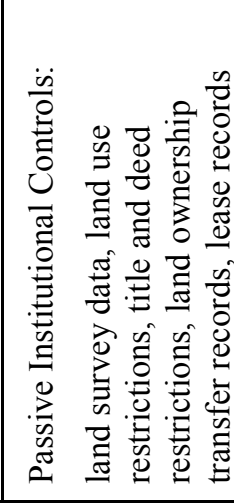 \\
\hline
\end{tabular}



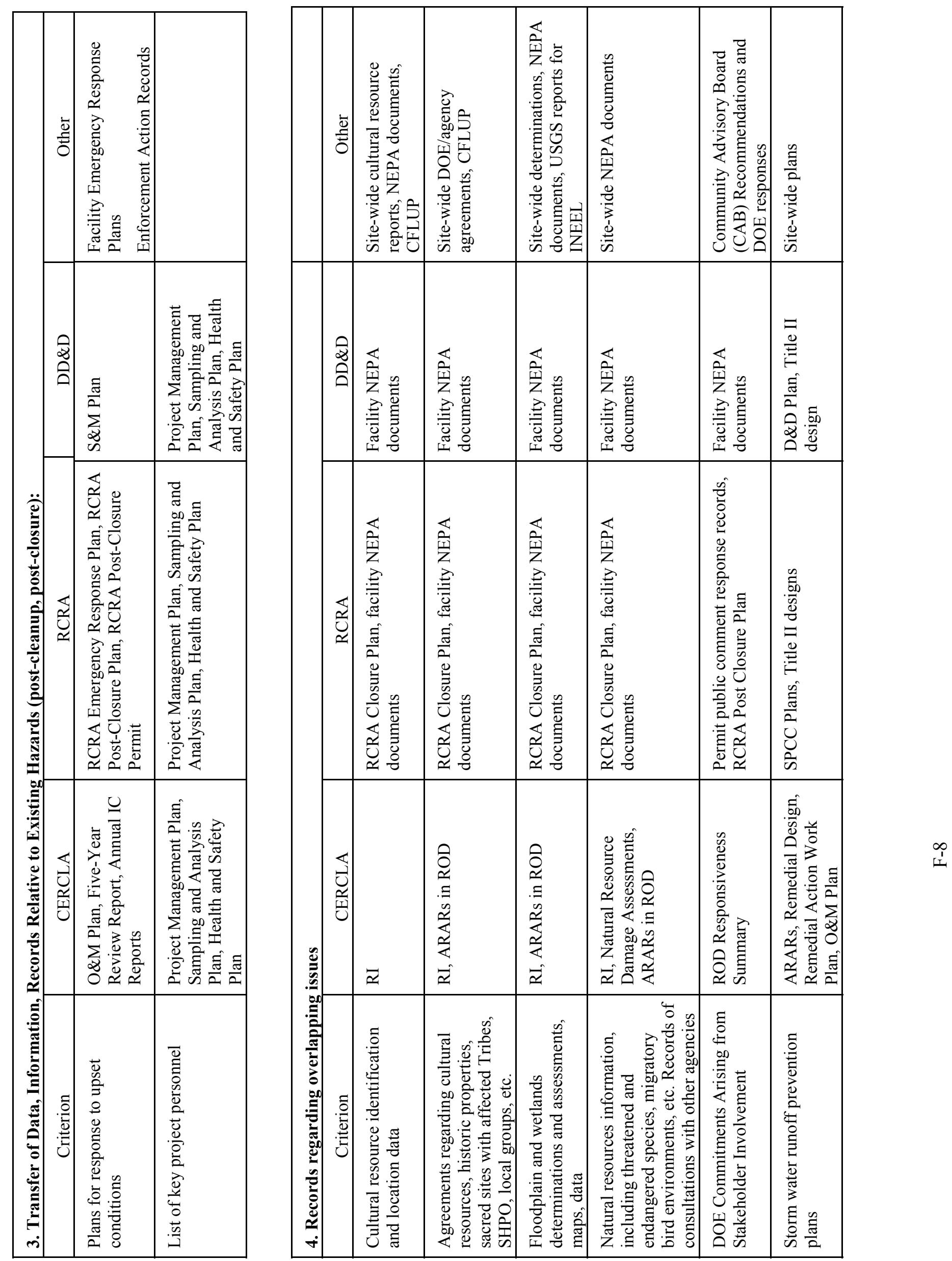

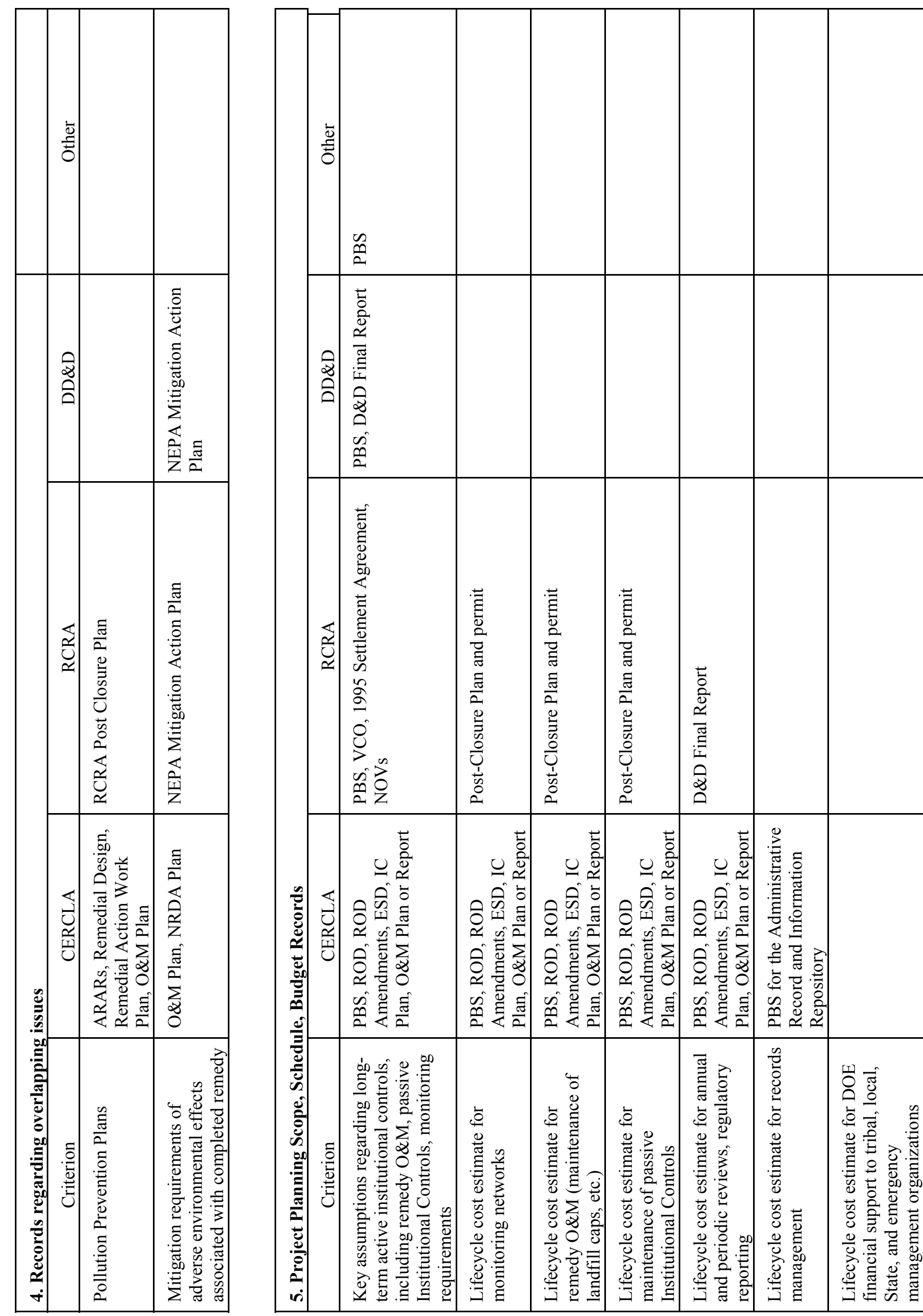


\begin{tabular}{|c|c|}
\hline & 猋 \\
\hline 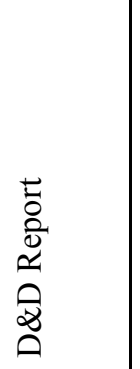 & \\
\hline 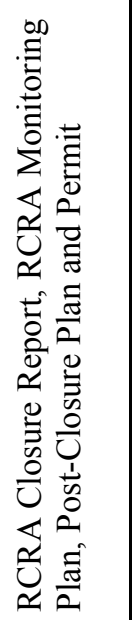 & \\
\hline 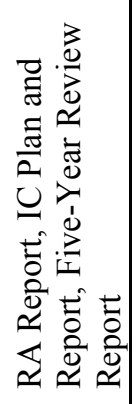 & \\
\hline 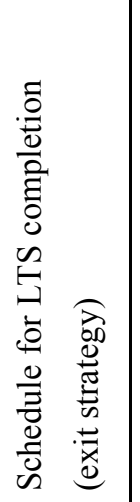 & 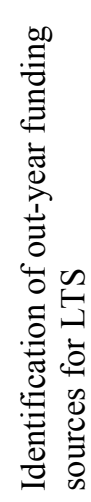 \\
\hline
\end{tabular}

$\frac{1}{1}$ 